Prepared in cooperation with the U.S. Army Corps of Engineers, Omaha District

\title{
Sediment Loads and Transport at Constructed Chutes along the Missouri River-Upper Hamburg Chute near Nebraska City, Nebraska, and Kansas Chute near Peru, Nebraska, 2012
}

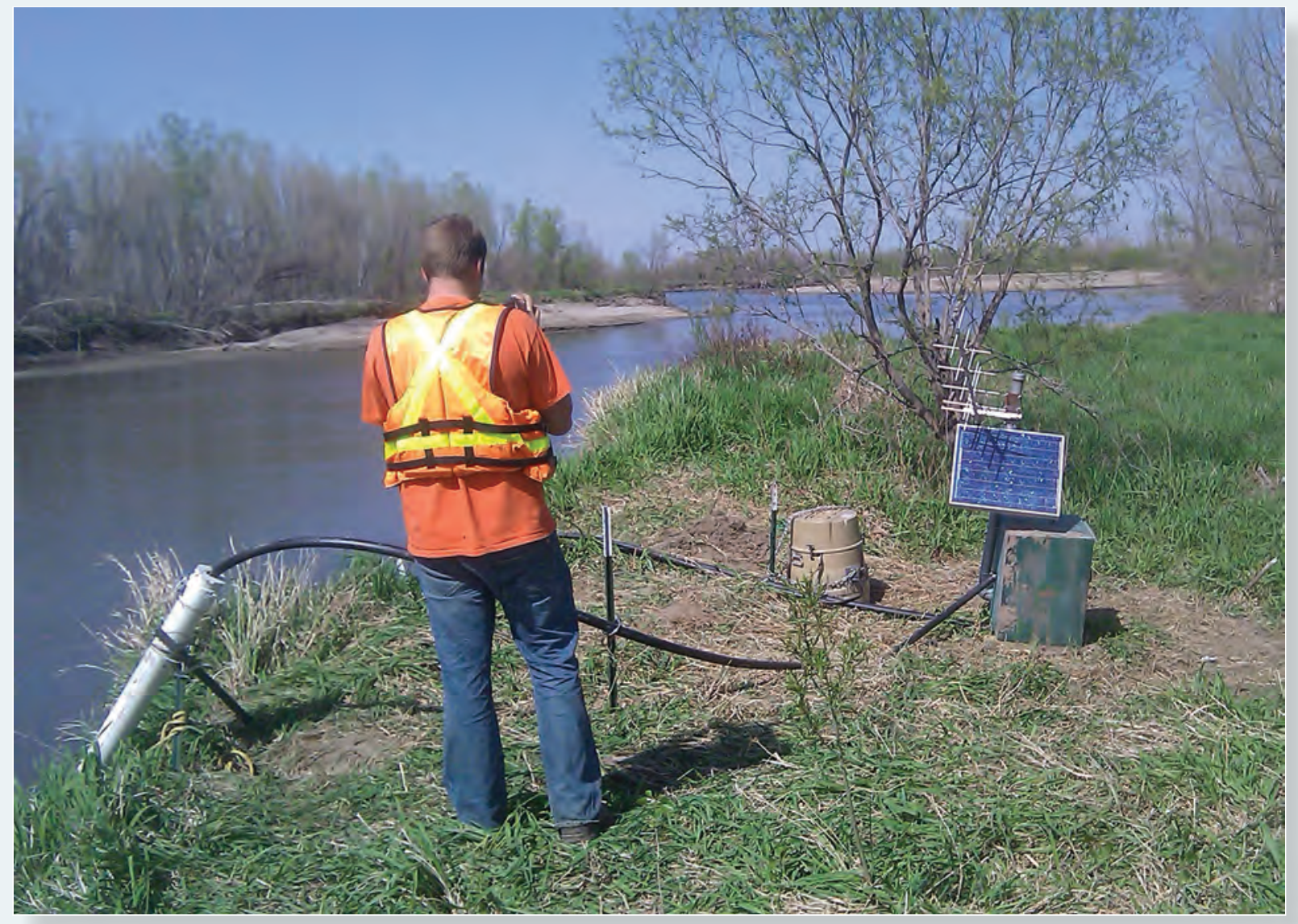

Scientific Investigations Report 2016-5002 
Cover photograph. U.S. Geological Survey Physical Scientist, Matt Moser, looking upstream and checking equipment on the left bank at Upper Hamburg chute downstream transect. Photograph taken by U.S. Geological Survey personnel. 


\section{Sediment Loads and Transport at Constructed Chutes along the Missouri River-Upper Hamburg Chute near Nebraska City, Nebraska, and Kansas Chute near Peru, Nebraska, 2012}

By Brenda K. Densmore, David L. Rus, Matthew T. Moser, Brent M. Hall, and Michael J. Andersen

Prepared in cooperation with the U.S. Army Corps of Engineers, Omaha District

Scientific Investigations Report 2016-5002 


\title{
U.S. Department of the Interior SALLY JEWELL, Secretary
}

\section{U.S. Geological Survey Suzette M. Kimball, Director}

\author{
U.S. Geological Survey, Reston, Virginia: 2016
}

For more information on the USGS - the Federal source for science about the Earth, its natural and living resources, natural hazards, and the environment—visit http://www.usgs.gov or call 1-888-ASK-USGS.

For an overview of USGS information products, including maps, imagery, and publications, visit http://www.usgs.gov/pubprod/.

Any use of trade, firm, or product names is for descriptive purposes only and does not imply endorsement by the U.S. Government.

Although this information product, for the most part, is in the public domain, it also may contain copyrighted materials as noted in the text. Permission to reproduce copyrighted items must be secured from the copyright owner.

Suggested citation:

Densmore, B.K., Rus, D.L., Moser, M.T., Hall, B.M., and Andersen, M.J., 2016, Sediment loads and transport at constructed chutes along the Missouri River-Upper Hamburg chute near Nebraska City, Nebraska, and Kansas chute near Peru, Nebraska, 2012: U.S. Geological Survey Scientific Investigations Report 2016-5002, 47 p. http://dx.doi. org/10.3133/sir20165002.

ISSN 2328-0328 (online) 


\section{Contents}

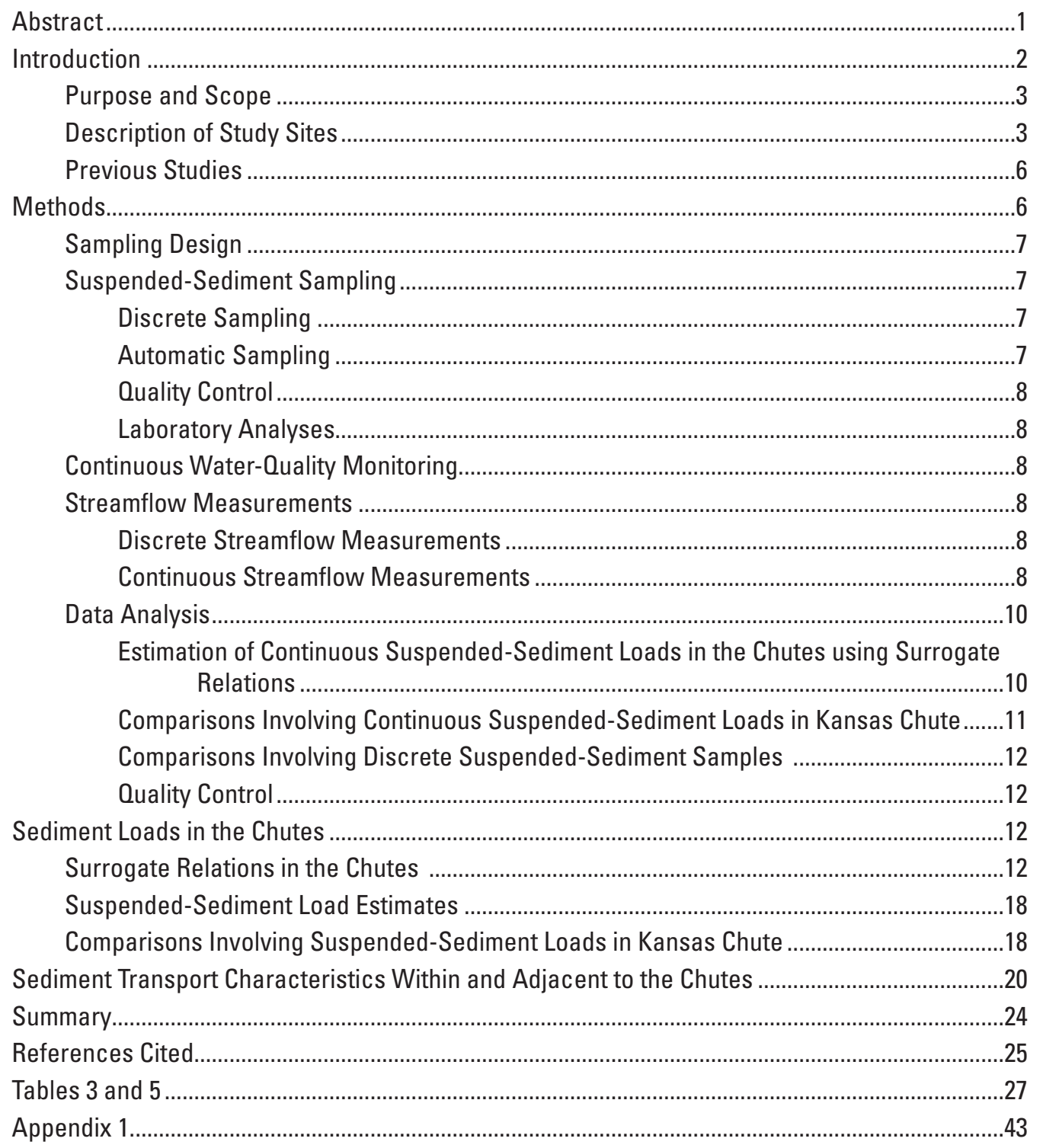




\section{Figures}

1. Aerial orthophotograph showing Upper Hamburg chute study site, 2012 ........................

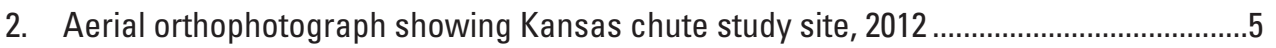

3. Graph showing Missouri River streamflow (measured U.S. Geological Survey streamflow-gaging station Missouri River near Nebraska City, Nebraska, 06807000 located at State Highway 2) during the operational period of Upper Hamburg chute and Kansas chute, 1996-2012.

4. Photographs showing Upper Hamburg chute downstream gage house with solar panel and autosampler on the bank and real-time continuous water-quality monitor conduit (white) running down the bank; autosampler on the bank and real-time continuous water-quality monitor conduit (white) running down into the chute deployed at Kansas chute upstream sampling location; real-time continuous water-quality monitor conduit (white) and acoustic Doppler velocimeter cables running down the bank at Kansas chute downstream sampling location; and Kansas chute downstream autosampler, gage house with solar panel and transmitting antenna, and sampling line and acoustic Doppler velocimeter cable running over the bank and into the chute.

5. Graphs showing streamflow and dates of physical samples, April through October 2012 at Upper Hamburg chute downstream, Kansas chute upstream, and Kansas chute downstream

6. Graphs showing fixed location in-stream turbidity and dates of physical samples, April through October 2012 at Upper Hamburg chute downstream, Kansas chute upstream, and Kansas chute downstream

7. Graphs showing turbidity in relation to total suspended-sediment concentration, including outliers excluded from regression analysis of data collected at Upper Hamburg chute downstream, Kansas chute upstream, and Kansas chute downstream

8. Graph showing difference in total daily suspended-sediment load estimate at Kansas chute upstream and Kansas chute downstream.

\section{Tables}

1. Summary of the model-calibration dataset and the time-series dataset at Upper Hamburg chute and Kansas chute

2. Regression equations for estimation of suspended sediment concentrations in two sediment size classes

4. Event loads calculated from instantaneous estimates of suspended-sediment concentrations from turbidity surrogate at Upper Hamburg and Kansas chute, 2012

6. Comparison of sediment characteristics between the Missouri River and the chutes and within the chutes using paired $t$-tests, 2012 and 2008. 


\section{Tables at the back of report}

3. Total daily loads calculated from instantaneous estimates of suspended-sediment concentration from turbidity surrogate at Upper Hamburg chute and Kansas

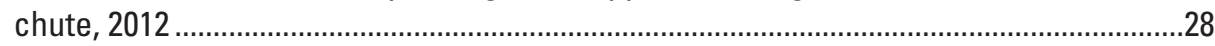

5. Daily 95-percent confidence intervals for suspended load estimates............................34

\section{Appendix 1}

1. Suspended sediment on the Missouri River main channel and within side channel chutes at Upper Hamburg Bend and Kansas Bend, 2012 


\section{Conversion Factors}

Inch/Pound to International System of Units

\begin{tabular}{|c|c|c|}
\hline Multiply & By & To obtain \\
\hline \multicolumn{3}{|c|}{ Length } \\
\hline inch (in.) & $2.54 \times 107$ & nanometer \\
\hline inch (in.) & 25.4 & millimeter $(\mathrm{mm})$ \\
\hline inch (in.) & 2.54 & centimeter $(\mathrm{cm})$ \\
\hline foot $(\mathrm{ft})$ & 0.3048 & meter $(\mathrm{m})$ \\
\hline mile (mi) & 1.609 & kilometer $(\mathrm{km})$ \\
\hline \multicolumn{3}{|c|}{ Area } \\
\hline acre & 0.4047 & hectare (ha) \\
\hline \multicolumn{3}{|c|}{ Volume } \\
\hline ounce, fluid (fl. oz) & 0.02957 & liter $(\mathrm{L})$ \\
\hline \multicolumn{3}{|c|}{ Flow rate } \\
\hline feet per second (ft/s) & 0.3048 & meter per second $(\mathrm{m} / \mathrm{s})$ \\
\hline cubic foot per second $\left(\mathrm{ft}^{3} / \mathrm{s}\right)$ & 0.02832 & cubic meter per second $\left(\mathrm{m}^{3} / \mathrm{s}\right)$ \\
\hline \multicolumn{3}{|c|}{ Mass } \\
\hline ton per day (ton/d) & 0.90702 & metric ton per day \\
\hline ounce $(\mathrm{oz})$ & 28.35 & gram \\
\hline \multicolumn{3}{|c|}{ Frequency } \\
\hline kilohertz $(\mathrm{kHz})$ & 1,000 & cycles per second \\
\hline
\end{tabular}

Temperature in degrees Celsius $\left({ }^{\circ} \mathrm{C}\right)$ may be converted to degrees Fahrenheit ( $\left.{ }^{\circ} \mathrm{F}\right)$ as follows:

${ }^{\circ} \mathrm{F}=\left(1.8 \times{ }^{\circ} \mathrm{C}\right)+32$.

\section{Datum}

Vertical coordinate information is referenced to the North American Vertical Datum of 1988 (NAVD 88).

Horizontal coordinate information is referenced to the North American Datum of 1983 (NAD 83).

\section{Supplemental Information}

Specific conductance is given in microsiemens per centimeter at 25 degrees Celsius $(\mu \mathrm{S} / \mathrm{cm}$ at $\left.25^{\circ} \mathrm{C}\right)$

Concentrations of chemical constituents in water are given either in milligrams per liter (mg/L) or micrograms per liter $(\mu \mathrm{g} / \mathrm{L})$.

Turbidity units given in formazin nephelometric units (FNU) instead of the more common nephelometric turbidity units (NTU). 


\section{Abbreviations}

\begin{tabular}{|c|c|}
\hline ADVMs & acoustic Doppler velocimeters \\
\hline $\mathrm{BiOp}$ & Missouri River Biological Opinion \\
\hline BSNP & Missouri River Bank Stabilization and Navigation Project \\
\hline EWI & equal-width increment \\
\hline FNU & formazin nephelometric units \\
\hline KANS-CH-DS & Kansas chute downstream \\
\hline KANS-CH-US & Kansas chute upstream \\
\hline KANS-MR-DS & Kansas Missouri River downstream \\
\hline KANS-MR-US & Kansas Missouri River upstream \\
\hline MLR & multiple linear regression \\
\hline NTU & nephelometric turbidity units \\
\hline SF & $\begin{array}{l}\text { sand-fines, that is, the threshold }(0.0625 \mathrm{~mm}) \text { between sand-size and } \\
\text { finer-than-sand-size particles of sediment }\end{array}$ \\
\hline SLR & simple linear regression \\
\hline SSC & suspended-sediment concentration \\
\hline $\mathrm{SSC}_{\text {auto }}$ & $\begin{array}{l}\text { suspended-sediment concentration from an autosampler (collected by } \\
\text { the programmable pumping sampler) }\end{array}$ \\
\hline $\mathrm{SSC}_{\mathrm{EWI}}$ & suspended-sediment concentration from equal-width increment samples \\
\hline SSiltC & suspended-silt-clay concentration \\
\hline SSandC & suspended-sand concentration \\
\hline SSL & total suspended-sediment load \\
\hline $\mathrm{SSL}_{\text {silt }}$ & silt-clay suspended-sediment load \\
\hline $\mathrm{SSL}_{\text {sand }}$ & sand suspended-sediment load \\
\hline SWH & shallow-water habitat \\
\hline UHAM-CH-DS & Upper Hamburg chute downstream \\
\hline UHAM-MR-DS & Upper Hamburg Missouri River downstream \\
\hline UHAM-MR-US & Upper Hamburg Missouri River upstream \\
\hline USACE & U.S. Army Corps of Engineers \\
\hline USGS & U.S. Geological Survey \\
\hline YSI & Yellow Springs Instrument Company (now known as YSI Inc.) \\
\hline
\end{tabular}





\title{
Sediment Loads and Transport at Constructed Chutes along the Missouri River-Upper Hamburg Chute near Nebraska City, Nebraska, and Kansas Chute near Peru, Nebraska, 2012
}

\author{
By Brenda K. Densmore, David L. Rus, Matthew T. Moser, Brent M. Hall, and Michael J. Andersen
}

\section{Abstract}

The U.S. Geological Survey, in cooperation with the U.S. Army Corps of Engineers, monitored suspended sediment within constructed Missouri River chutes during March through October 2012. Chutes were constructed at selected river bends by the U.S. Army Corps of Engineers to help mitigate aquatic habitat lost through the creation and maintenance of the navigation channel on the Missouri River. The restoration and development of chutes is one method for creating shallow-water habitat within the Missouri River to meet requirements established by the amended 2000 Biological Opinion. Understanding geomorphic channel-evolution processes and sediment transport is important for the design of chutes, monitoring and maintenance of existing chutes, and characterizing the habitat that the chutes provide. This report describes the methods used to monitor suspended sediment at two Missouri River chutes and presents the results of the data analysis to help understand the suspended-sediment characteristics of each chute and the effect the chutes have on the Missouri River. Upper Hamburg chute, near Nebraska City, Nebraska, and Kansas chute, near Peru, Nebraska, were selected for monitoring. At each study site, monthly discrete samples were collected from April through October in the Missouri River main-channel transects upstream from the chute inlet, downstream from the chute outlet, at the outlet (downstream transect) of both chutes, and at the inlet (upstream transect) of Kansas chute. In addition, grab samples from all chute sampling locations were collected using autosamplers. Suspended-sediment concentration (SSC) and grain-size metrics were determined for all samples (discrete and grab). Continuous water-quality monitors recorded turbidity and water temperature at 15 -minute intervals at the three chute sampling locations. Two acoustic Doppler velocimeters, one within each chute, measured water depth and current velocities continuously. The depth and velocity data were used to estimate streamflow within each chute. The sampling design was developed to understand the suspended-sediment differences within each chute and between the chute and the Missouri River main channel during discrete sampling. The sampling design also allowed for site-specific surrogate relations between SSC and turbidity to be developed, which could be used to compute real-time estimates of SSC and sediment loads within the chutes. Real-time estimates of SSC and sediment loads enable a better understanding of sediment transport within the chutes during times when physical samples are not collected, including periods of high flow.

High flows during the summer of 2011 resulted in substantial alterations to both studied chutes; therefore, the U.S. Army Corps of Engineers repaired and modified both chutes during 2012. These unforeseen repairs and modifications within the chutes added uncertainty to the analysis because concentrations were altered by construction equipment and flow alteration.

Daily suspended-sediment and suspended-silt loads were estimated based on surrogate relations with turbidity. A linear regression was used to estimate equal-width increment (EWI)-equivalent SSC from autosampler SSC before using the model-calibration dataset to determine the best-fit model for prediction of SSC from the turbidity and, in some cases, discharge. Correlation between suspended-sand concentration (SSandC) in EWI samples and concurrent samples collected by an autosampler was low; therefore, SSandC was excluded from development of surrogate relations because a large part of the calibration dataset was from autosamples. Instead, SSandC was estimated as SSC minus suspended-siltclay concentration (SSiltC). At all sites, the best-fit models included the base-10 logarithm of concentration and turbidity, and at Kansas chute upstream, the base-10 logarithm of streamflow was also included in the best-fit models. These surrogate models were used to estimate continuous time series of SSC and SSiltC. Estimated concentrations of suspended sediment were used to estimate instantaneous and daily loads for total suspended sediment, suspended silt-clay, and suspended sand. Estimated daily suspended-sediment loads were not significantly different between upstream and downstream 
transects within the Kansas chute, and most individual daily loads within the chute were not significantly different between upstream and downstream transects when evaluated using overlap in daily 95 -percent confidence intervals. The comparison of daily load values for upstream and downstream chute transects, as estimated from turbidity-based surrogate models for Kansas chute, documents the daily dynamic nature of sediment transport within the chute with a temporal resolution that is not practical with discrete suspended-sediment sampling alone.

Comparisons of concentrations and loads from EWI samples collected from different transects within a study site resulted in few significant differences, but comparisons are limited by small sample sizes and large within-transect variability. When comparing the Missouri River upstream transect to the chute inlet transect, similar results were determined in 2012 as were determined in 2008 - the chute inlet affected the amount of sediment entering the chute from the main channel. In addition, the Kansas chute is potentially affecting the sediment concentration within the Missouri River main channel, but small sample size and construction activities within the chute limit the ability to fully understand either the effect of the chute in 2012 or the effect of the chute on the main channel during a year without construction. Finally, some differences in SSC were detected between the Missouri River upstream transects and the chute downstream transects; however, the effect of the chutes on the Missouri River mainchannel sediment transport was difficult to isolate because of construction activities and sampling variability.

\section{Introduction}

The restoration and preservation of Missouri River habitat and fish and wildlife species is a focus for numerous government agencies and the public. Development on the Missouri River, including the Missouri River main stem reservoir system and the operation and maintenance of the Missouri River Bank Stabilization and Navigation Project (BSNP), has modified the availability of aquatic and terrestrial habitat in the river corridor (Funk and Robinson, 1974). The U.S. Army Corps of Engineers (USACE) has led numerous Missouri River projects as part of the BSNP Fish and Wildlife Mitigation Program that began in 1986 (Reinig and Roth, 2010). The goal of the BSNP Fish and Wildlife Mitigation Program was to restore fish and wildlife habitat that was lost or damaged because of the channelization and bank stabilization of the river downstream from Sioux City, Iowa (fig. 1). Since 1996, chutes have been constructed at selected river bends by the USACE to help mitigate aquatic habitat lost. The 2000 Missouri River Biological Opinion (BiOp; U.S. Fish and Wildlife Service, 2000) determined that the operation of the Missouri River main stem reservoir system and the operation and maintenance of the Missouri River BSNP jeopardized threatened and endangered species. The BiOp suggested as part of a reasonable and prudent alternative the creation or restoration of 20-30 acres per river mile of shallow-water habitat (SWH; U.S. Fish and Wildlife Service, 2000). The BiOp defined SWH to be less than 5 feet deep and with current velocity less than 2 feet per second. The restoration and development of chutes is one method for creating SWH (U.S. Army Corps of Engineers, 2014). Chutes are small, typically shallow, side channels that provide more diverse habitat than the main navigation channel, with a variety of substrates, depths, and velocities. Chutes are constructed by excavating a shallow pilot channel through the bottomland so the water can flow from the river into the chute at the inlet and re-enter the river downstream at the chute outlet. Chutes are designed with vertical grade control structures that typically are at the inlet or outlet, or both. The structures reduce the effects that the chute may otherwise have on the navigation channel. The constructed chutes then widen and meander as a result of geomorphic processes such as bank erosion, aggradation or degradation of the bed, or meander migration (U.S. Army Corps of Engineers, 2014).

Understanding geomorphic evolution of chutes and their sediment transport is important for designing new chutes, maintenance and monitoring of existing chutes, and characterizing the habitat that the chutes provide. Chutes have different sediment-transport characteristics than the main channel and the contribution of the chutes to the river sediment budget is largely unquantified. Understanding fluvial processes within chute boundaries and how chutes function biologically are fundamental to ensure that the habitat developed is sustained and satisfies the needs of the Missouri River biota. Monitoring is necessary to evaluate the habitat being provided, to understand how the chute is affecting the Missouri River main channel, to evaluate geomorphic change and longevity, and to understand the overall effectiveness of the chutes at restoring Missouri River habitat. The biological community and the physical structure of SWH sites have been monitored annually since 2005 (Sterner and others, 2009; Gosch and others, 2015; Krahulik and others, 2015). During March through October of 2012, the U.S. Geological Survey (USGS), in cooperation with the USACE, monitored suspended sediment within two selected Missouri River chutes; discrete suspended-sediment samples and real-time continuous water-quality data were collected. The objectives of the study were (1) to provide sediment and water-quality data on chutes to better understand their geomorphic processes; (2) to quantify and compare suspended-sediment concentrations (SSC), loads, and size distributions of the chutes to those of the Missouri River main channel; (3) to determine variation among water-quality properties within chutes; and (4) to develop a model of the relation between turbidity and SSC that evaluates the use of turbidity as a surrogate for SSC. Objective 2 will help answer questions such as (1) does the chute sediment load produce a measurable difference in the main-channel sediment load, (2) do the chute sediment characteristics change from upstream to downstream, and (3) are the sediment characteristics within the upstream 
section of the chute different than those within the Missouri River main channel upstream from the chute?

The benefit of using continuous water-quality monitoring has been demonstrated in previous surface-water monitoring (Christensen, 2001; Rasmussen and others, 2005). Turbidity is a measure of the clarity of water that is affected by suspended matter such as sediment, particulate-organic matter, plankton, and other microscopic organisms (U.S. Geological Survey, variously dated). More specifically, turbidity is a measure of the optical properties of water that cause light to be scattered or absorbed. Turbidity serves as a proxy for suspended sediment and is sensitive to sediment delivery from erosional processes. Erosional processes include eroded upland sediment transported to the stream during rainfall runoff and bank failures that generally are either coincident with runoff or follow runoff because of increased streamflow. The suspended particles associated with turbidity provide attachment sites for bacteria, metals, nutrients, and pesticides (Rasmussen and others, 2005). The particles may disturb aquatic communities, and the particles may lead to sedimentation problems. Water temperature plays a critical role in the chemistry of freshwater ecosystems by affecting the solubility of dissolved constituents, conductance, biological activity, and rates of reactions (U.S. Geological Survey, variously dated).

The use of statistical relations to predict the concentration of water-quality constituents based on their relation to continuously measured properties of water (surrogates) is a valid technique (Rasmussen and others, 2005; Schaepe and others, 2014). Turbidity is commonly used as a surrogate for the measurement of SSC (Rasmussen and others, 2005). Combining continuous turbidity and streamflow measurements with discrete suspended-sediment sampling allows for the computation of a time-series record of the SSC and load within a waterway (Rasmussen and others, 2009). The method described in Rasmussen and others (2009) has been widely used and provides reliable time series of SSC with low uncertainty values through the development of regression equations (Rasmussen and others, 2009; Schaepe and others, 2014).

\section{Purpose and Scope}

The purpose of this report is to present the results of the data analysis to improve the understanding of the suspendedsediment load and transport processes of constructed chutes, Upper Hamburg near Nebraska City, Nebr., and Kansas Chute near Peru, Nebr., and the effect the chutes have on the Missouri River. Discrete suspended-sediment samples were collected during April through October 2012, and real-time continuous water-quality monitoring recorded turbidity and water temperature at 15 -minute intervals during March through October 2012. This report describes the methods used to monitor suspended sediment at two Missouri River chutes and presents the results of the data analysis.

\section{Description of Study Sites}

Missouri River chutes selected for monitoring include Upper Hamburg chute (fig. 1) on the right bank (looking downstream) at river mile 552-556 and Kansas chute (fig. 2) on the right bank at river mile 544-546. Upper Hamburg Bend and its associated chute are in Otoe County in Nebraska and are approximately 5.6 miles (mi) downstream from the State Highway 2 bridge at Nebraska City, Nebr. (fig. 1). Kansas Bend and its associated chute are in Otoe and Nemaha Counties in Nebraska and are approximately $15 \mathrm{mi}$ downstream from the State Highway 2 bridge at Nebraska City, Nebr. near Peru, Nebr. (fig. 2). Upper Hamburg chute was constructed in 1996, and Kansas chute was constructed in 2004. In 2012, Upper Hamburg chute was approximately $3 \mathrm{mi}$ long and averaged 430 feet wide, and Kansas chute was approximately $1.2 \mathrm{mi}$ long and averaged 260 feet wide. Upper Hamburg chute is a more mature chute and Kansas chute is newer. Mature chutes might be more stable and closer to equilibrium, whereas a newer chute might be expected to be rapidly evolving. A chute in equilibrium is theoretically able to transport its sediment load during high-flow events without significant degradation or aggradation to the channel, and lateral movement is offset within the chute. As described in Woodward and Rus (2011), the streamflow regime imposed on each chute is an important factor that affects chute evolution. The hydraulic power of streamflow provides the sediment-transport mechanism by which the chutes erode or aggrade toward their chute-specific equilibrium state. Upper Hamburg chute and Kansas chute are close in proximity; therefore, the measured streamflow was similar for both chutes after 2004. During 1996-2012, the most geomorphically effective peak streamflow was in 2011 for both chutes (fig. 3).

High flows during the summer of 2011 resulted in substantial alterations to the chutes; therefore, the USACE repaired and modified both chutes during 2012 (U.S. Army Corps of Engineers and U.S. Fish and Wildlife Service, 2013). At Upper Hamburg chute, the inlet was modified and closed, and two grade control structures were constructed. Additionally, a large scour hole that threatened the toe of the nearby levee was filled, and the chute banks were restored and protected near the scour hole (fig. 1). The inlet was closed on July 6, 2012, and remained closed for the remainder of the study. The inlet was closed off with riprap (high porosity) such that flow was still observed in the chute following the closure. The downstream grade control structure was completed by August 1, 2012, and the upstream grade control structure was completed by February 15, 2013. At Kansas chute, the inlet structure was modified and enhanced, a grade control structure was added, and three spur dikes were installed (fig. 2). The upstream spur dike, completed in early June 2012, was installed approximately 328 feet upstream from, and on the same bank as, the real-time continuous water-quality monitor and autosampler at the upstream sampling location. All 


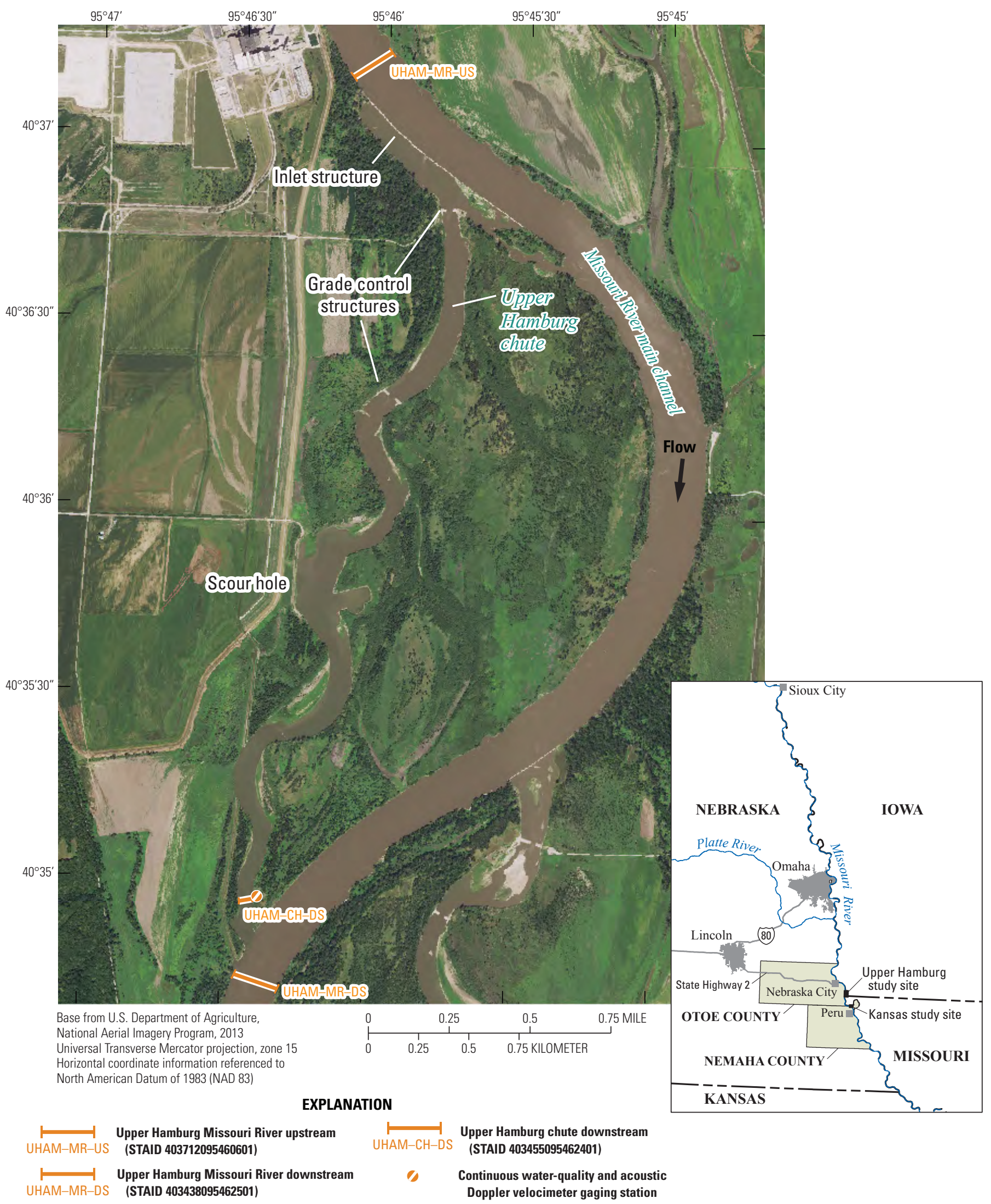

STAID, U.S. Geological Survey station identific ation number

Figure 1. Aerial orthophotograph showing Upper Hamburg chute study site, 2012. 


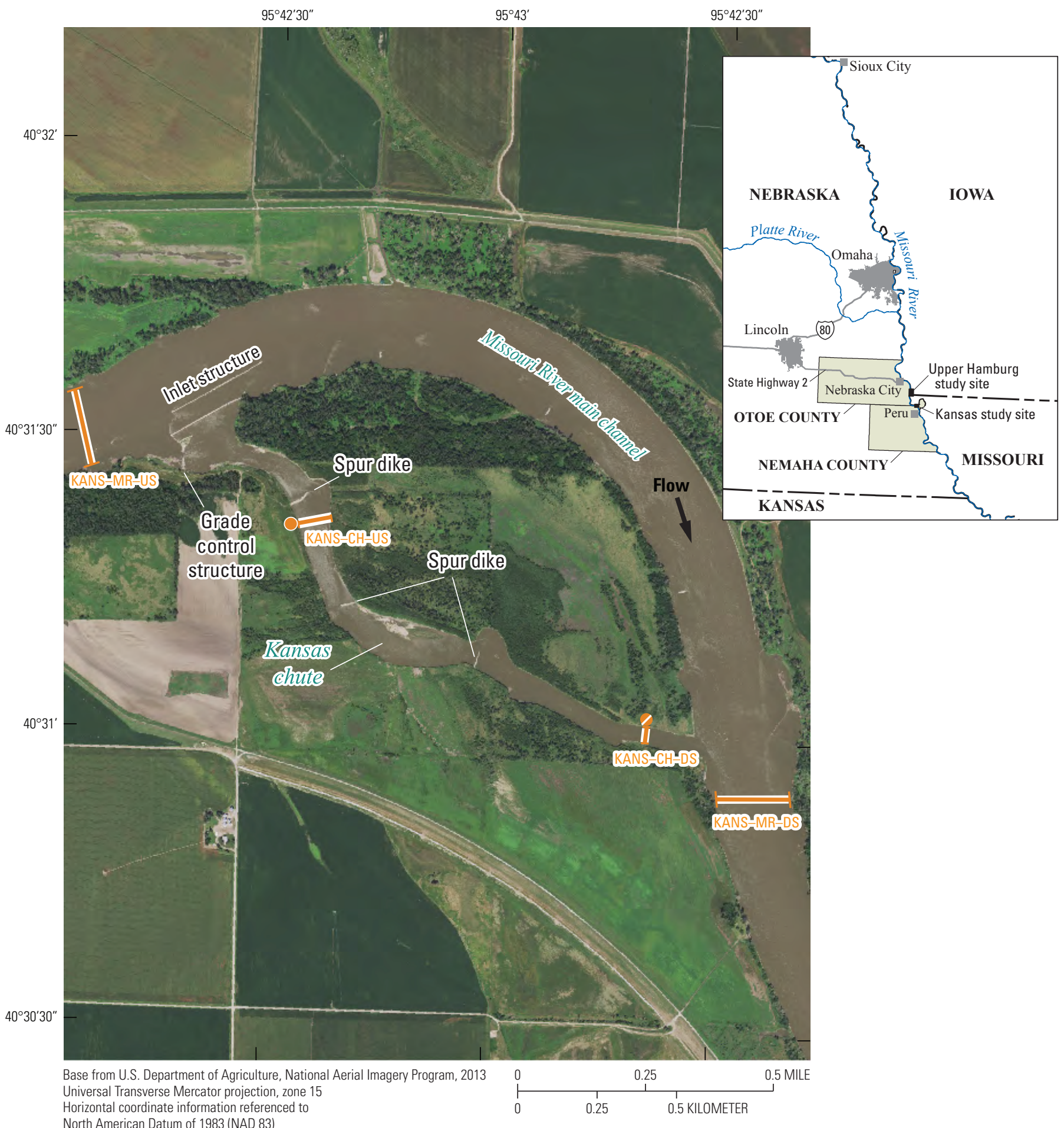

\section{EXPLANATION}

\begin{tabular}{l|l} 
Kansas Missouri River upstream \\
\hline
\end{tabular} KANS-MR-US (STAID 403126095435301) Kansas Missouri River downstream
KANS-MR-DS

\section{Kansas chute upstream KANS-CH-US (STAID 403135095431201) \\ Kansas chute downstream KANS-CH-DS (STAID 403134095431101)}

$95^{\circ} 42^{\prime} 30^{\prime \prime}$ 


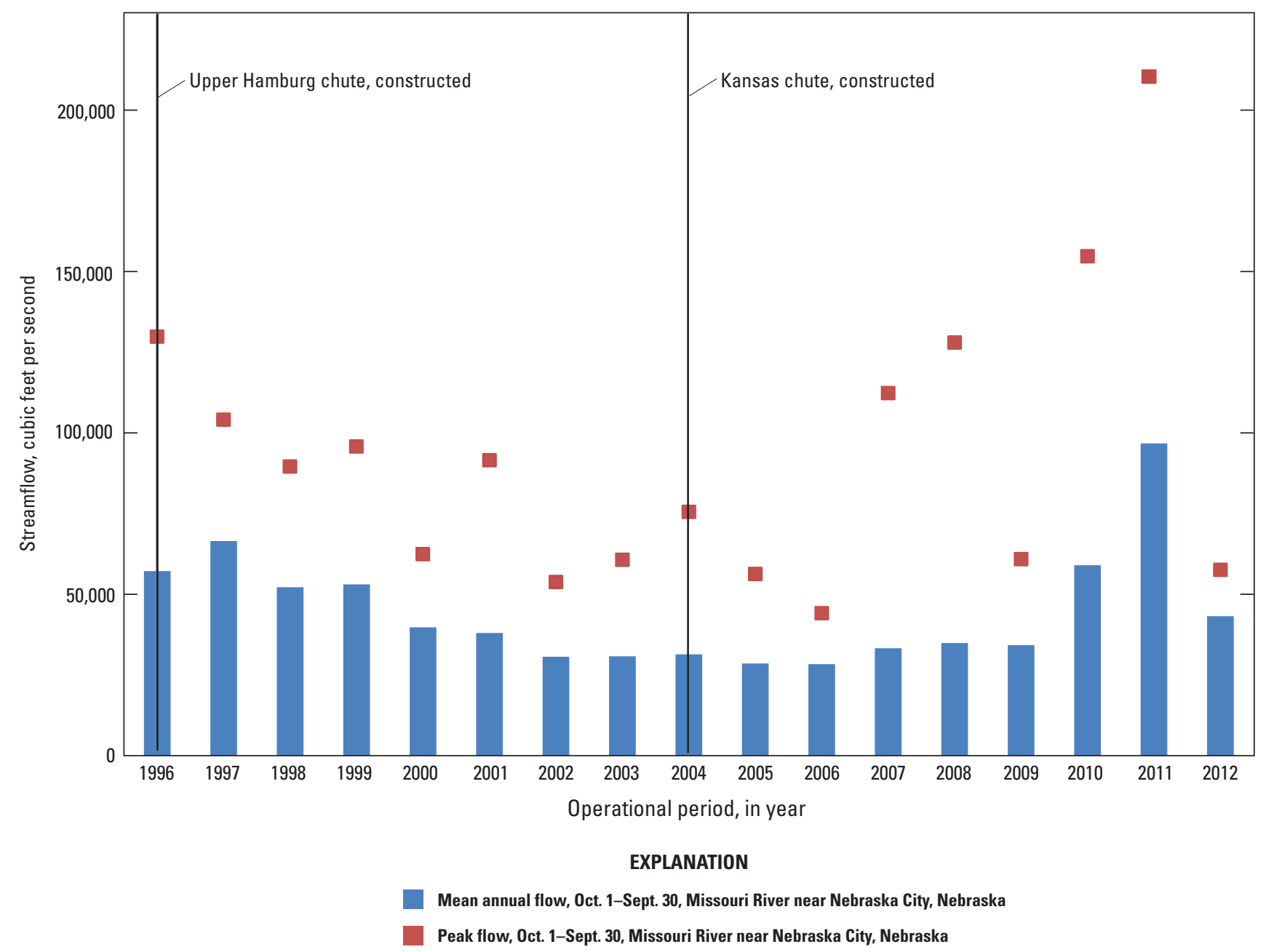

Figure 3. Missouri River streamflow (measured U.S. Geological Survey streamflow-gaging station Missouri River near Nebraska City, Nebraska, 06807000 located at State Highway 2) during the operational period of Upper Hamburg chute and Kansas chute, 1996-2012.

structures were completed at Kansas chute by June 29, 2012. The construction and maintenance activities were not typical but were necessary to maintain the chutes following the flooding of 2011. The chute repairs and modifications are referred to as construction activities or construction throughout this report. These unforeseen repairs and modifications within the chutes added uncertainty to the analysis because sediment concentrations within both chutes were altered by construction equipment and flow alteration.

\section{Previous Studies}

The sediment characteristics of Missouri River chutes and the main channel were investigated based on discrete suspended- and streambed-sediment samples by Woodward and Rus (2011). Results indicated that the inlet structures tended to restrict coarse suspended sediments from entering the chutes from the Missouri River main channel. A statistical difference in the suspended-sediment characteristics did not exist between the inlet and outlet of the chutes, and the chutes did not significantly change the sediment characteristics of the main channel. The report noted that the small number of samples constrained the statistical power to detect subtle differences (Woodward and Rus, 2011).

\section{Methods}

The following sections describe the sampling design for this study and the methods used to collect monthly suspendedsediment samples, operate real-time continuous water-quality monitors, measure streamflow, and operate acoustic Doppler velocimeters (ADVMs). This section also describes data analysis methods. 


\section{Sampling Design}

At each monitored chute, the following four sampling transects were established-Missouri River main-channel transect upstream from the chute inlet, main-channel transect downstream from the chute outlet, within-chute transects near the upstream end, and within-chute transects near the downstream end. Transects at Upper Hamburg chute study site are referred to as Upper Hamburg Missouri River upstream (UHAM-MR-US; fig. 1), Upper Hamburg Missouri River downstream (UHAM-MR-DS; fig. 1), Upper Hamburg chute upstream (not shown), and Upper Hamburg chute downstream (UHAM-CH-DS; fig. 1). Upper Hamburg chute upstream transect was not sampled because of chute closure and construction activities. Similarly, transects at Kansas chute study site are referred to as Kansas Missouri River upstream (KANS-MR-US; fig. 2), Kansas Missouri River downstream (KANS-MR-DS; fig. 2), Kansas chute upstream (KANS-CHUS; fig. 2), and Kansas chute downstream (KANS-CH-DS; fig. 2).

At each study site, monthly suspended-sediment samples were collected from April through October 2012 in Missouri River main-channel transects upstream from the chute inlet and downstream from the chute outlet. Monthly suspendedsediment samples were also collected from April through October 2012 at the chute transects (UHAM-CH-DS, KANS$\mathrm{CH}-\mathrm{US}$, and KANS-CH-DS). These discrete samples were collected from the channel transect at equal-width increments (EWI) using a depth-integrated, isokinetic method (Edwards and Glysson, 1999). In addition, grab samples were collected for all three chute sampling locations by using autosamplers throughout the study period. Continuous water-quality monitors recorded turbidity and water temperature at 15 -minute intervals during March through October 2012 at three chute sampling locations (UHAM-CH-DS, KANS-CH-US, and KANS-CH-DS) and transmitted the data in near real time to the USGS database and Web site (U.S. Geological Survey, 2012).

In addition to water sampling, two ADVMs were deployed, one at Upper Hamburg chute and one at Kansas chute. The ADVMs continuously measured water depth and current velocities in real-time and transmitted the information from the up-looking beam and selected ensembles back to the USGS Web site. Measured depth and velocity were used to estimate continuous streamflow within the chutes after a relation was defined on the basis of discrete streamflow measurements made during sampling and equipment maintenance trips (Levesque and Oberg, 2012).

The sampling design was developed to understand the suspended-sediment differences within each chute and to understand the differences between the chute and the Missouri River main channel during discrete sampling. The sampling design also was developed to expand on site-specific surrogate relations between SSC and turbidity, which could be used to compute real-time estimates of SSC and sediment loads within the chutes. This design provides the potential to improve understanding of sediment transport within the chutes during times when physical samples are not collected, including during periods of high flow that can be protracted on large rivers.

\section{Suspended-Sediment Sampling}

The SSCs were determined for water samples collected using two methods. Monthly discrete (or manually collected) samples were collected from a boat at all sampling transects. "Automatic samples" were collected by programmed pumping samplers (autosamplers) from a point near the bank at chute sampling transects.

\section{Discrete Sampling}

All water samples were collected following the accepted protocols of the USGS (U.S. Geological Survey, variously dated; Edwards and Glysson, 1999). All transects at each study site were unwadeable; therefore, a US DH-2 sampler (suspended-sediment/water-quality collapsible-bag sampler capable of isokinectically collecting a 1-L sample; Davis, 2005) was transited through the water column using a crane and reel mounted on the bow of a boat. In all cases, a constant, isokinetic transit rate (Edwards and Glysson, 1999) was used to collect the sample at each vertical station along a transect. Samples were collected at the center vertical from each of 10 EWI of a transect and composited into a polyethylene churn-splitter container. These composited samples are henceforth referred to as EWI samples. Subsequently, an aliquot was split from the composite sample and submitted for laboratory analysis.

Turbidity was recorded in conjunction with the suspended-sediment sampling. An aliquot of the composite sample was split from the churn for turbidity analysis. Turbidity readings were recorded of five different aliquots and the median value of five readings was documented. Turbidity was measured using a calibrated Yellow Springs Instrument Company (YSI) 6136 turbidity probe onsite.

\section{Automatic Sampling}

Grab samples for all chute sampling locations were collected using ISCO autosamplers (Teledyne $\mathrm{Isco}^{\mathrm{TM}}$, Lincoln, Nebr.). The autosampler was deployed on the bank with tubing extended to the water with a maximum head difference of approximately 14 feet. The orifice of the line was deployed approximately 1 foot below the surface and 2 feet from the streambed at time of deployment. The autosamplers were equipped with stage triggers that would enable the autosampler and begin the sampling when the stage of the chute overtopped the trigger device; the triggering devices were set at various stages. Once triggered, the autosamplers collected samples every 6 hours until a maximum of 24 possible samples were collected. Midway through the year, the autosamplers were converted from stage-triggered sampling to a 
scheduled sampling interval. The lack of high flows combined with faulty triggering of the autosamplers necessitated the change. A new sampling interval was established and samples were collected at noon every 2 days throughout the remainder of the year.

Turbidity values that correspond to autosampler grab samples were recorded from the continuous water-quality monitor deployed at the chute sampling location. When grab samples from the autosampler did not fall exactly on the 15-minute interval of the turbidity reading, the turbidity value closest in time was used.

\section{Quality Control}

During 10 EWI sampling events, the autosamplers were triggered to collect a concurrent sample; however, after data evaluation only 7 pairs of concurrent EWI and autosampler results were usable. In addition, sequential replicates samples were collected for 6 percent of the EWI samples (49 EWI samples collected, 3 replicates) to document the precision and reproducibility in field sampling procedures. Sequential replicate samples were collected immediately after the primary sample at the same transect using a separate set of sampling equipment.

\section{Laboratory Analyses}

Samples were analyzed by the USGS Iowa Sediment Laboratory at Iowa City, Iowa, for total SSC and the fraction of sediment mass finer than sand or sand-fines, that is, the threshold $(0.0625 \mathrm{~mm})$ between sand-size and finer-thansand-size particles of sediment (SF; also referred to as SF split in this report). A subset of samples also was analyzed for grain-size distribution using a visual-accumulation-tube technique (Guy, 1969). This technique characterized samples by determining the corresponding fractions of suspended sediment finer than $0.0625,0.125,0.25$, and $0.5 \mathrm{~mm}$ in diameter. Suspended-silt-clay concentration (SSiltC) is defined as particles finer than $0.062 \mathrm{~mm}$ in diameter and is calculated as SSC x SF split / 100 for all EWI samples. Suspended-sand concentration $(S S a n d C)$ is defined as particles larger than $0.062 \mathrm{~mm}$ in diameter and is calculated as SSC x $(100-\mathrm{SF}$ split) / 100 for all EWI samples. The SSiltC includes silt and clay in suspension, and SSandC includes only sand; gravel is not likely present in the suspended load of a low-gradient river (Edwards and Glysson, 1999).

\section{Continuous Water-Quality Monitoring}

Real-time continuous water-quality monitors were deployed at three locations (UHAM-CH-DS, KANS-CH-US, and KANS-CH-DS) from late March to late October 2012 (fig. 4). Deployment configurations included a polyvinylchloride conduit that was anchored to the bank and protected the meter and the communications cable.
Each monitor recorded at a 15 -minute interval and provided a continuous record of turbidity and water temperature. Monitors were operated and maintained in accordance with the standard procedures described in Wagner and others (2006). This study used model 6136 sensors that measure the amount of light scattered at a right angle from a near-infrared light source. The sensors were developed by YSI, Incorporated (Yellow Springs, Ohio) to collect turbidity measurements. Because the sensors use a near-infrared light rather than a white (broad spectrum) light source, turbidity is reported in formazin nephelometric units (FNU) instead of the more common nephelometric turbidity units (NTU; U.S. Geological Survey, variously dated). These reporting units are compatible in standard solutions but may deviate in environmental samples (U.S. Geological Survey, variously dated). The probes can accurately measure turbidity to approximately 1,000 FNU; a lower reporting limit of 1 FNU was assigned for this study.

\section{Streamflow Measurements}

Streamflow measurements were made using discrete methods, and streamflow was estimated using the index velocity method from continuous velocity and stage data from an ADVM; both methods followed USGS standard protocols. Discrete measurements were made monthly in association with sampling in the Missouri River main channel and in the chute. Continuous streamflow records were produced only within the chutes.

\section{Discrete Streamflow Measurements}

Discrete streamflow measurements were made during March through October 2012 following USGS standard protocols (Oberg and others, 2005; Mueller and Wagner, 2009). All streamflow measurements were made using an acoustic Doppler current profiler mounted to a boat in association with a differentially corrected global positioning system receiver. During each sampling event, streamflow was measured at one main-channel transect and one chute transect. Concurrent streamflow for all other transects at that study site was estimated from the two measurements.

\section{Continuous Streamflow Measurements}

A Sontek 1500-kilohertz Argonaut SL (YSI Sontek, San Diego, California) ADVM was deployed on the left bank at the downstream sampling location of each monitored chute. The ADVMs send out an acoustic pulse of a known frequency. The acoustic pulse is reflected by small particles in the water, returning to the transducer at a frequency that has been shifted because of the Doppler effect. The water velocity is determined on the basis of the change in the transmitted acoustic frequency and the geometric configuration of the transducers (SonTek Corporation, 2000; Ruhl and Simpson, 2005). The ADVMs were mounted on 2-inch galvanized pipes that were 

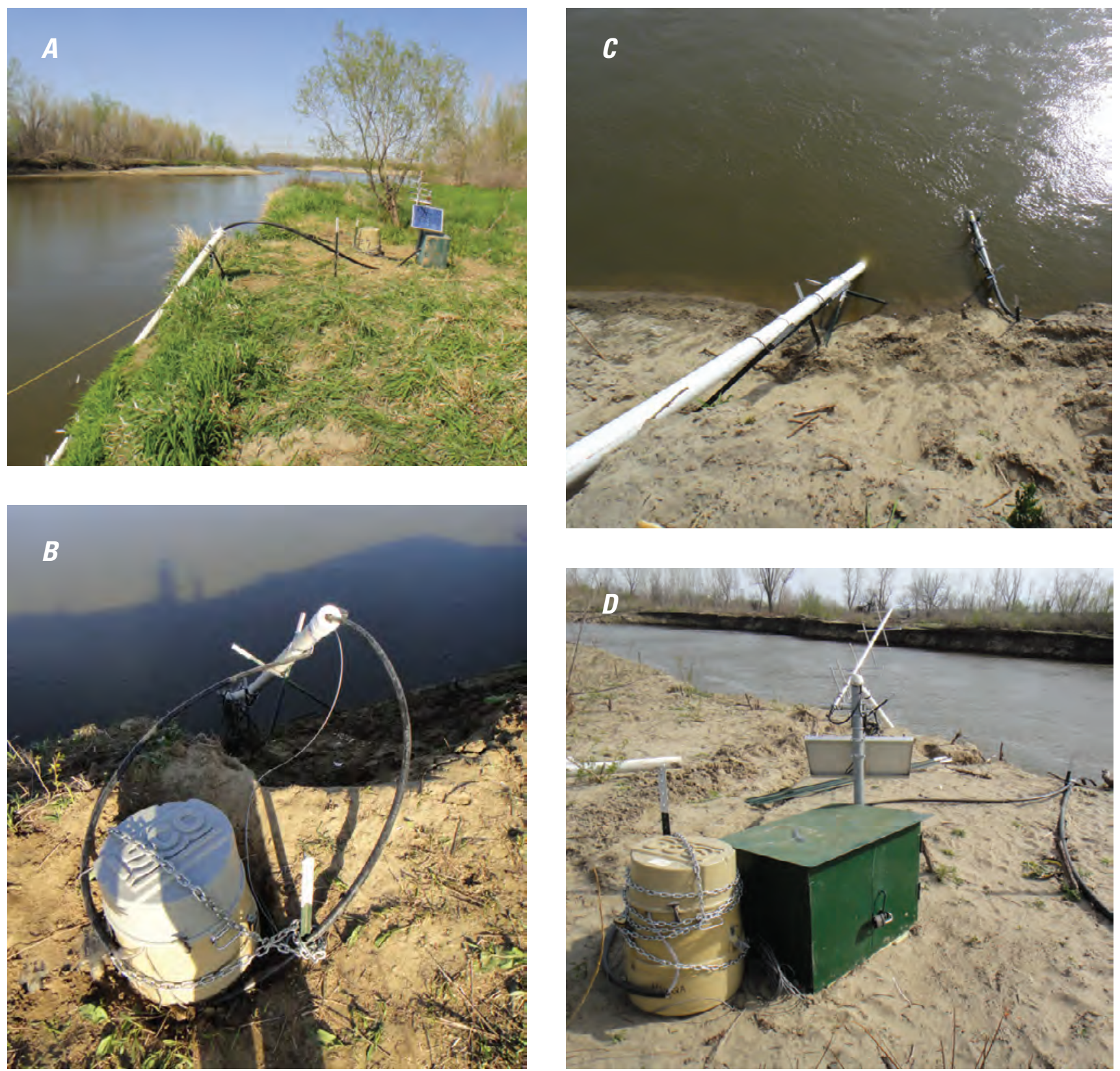

Figure 4. Photographs showing $(A)$ Upper Hamburg chute downstream gage house with solar panel and autosampler on the bank and real-time continuous water-quality monitor conduit (white) running down the bank; $(B)$ autosampler on the bank and real-time continuous water-quality monitor conduit (white) running down into the chute deployed at Kansas chute upstream sampling location; $(C)$ real-time continuous water-quality monitor conduit (white) and acoustic Doppler velocimeter cables running down the bank at Kansas chute downstream sampling location; and $(D)$ Kansas chute downstream autosampler, gage house with solar panel and transmitting antenna, and sampling line and acoustic Doppler velocimeter cable running over the bank and into the chute. 
anchored to the bank and into the streambed. When mounted, the ADVMs were oriented to emit a 2-beam horizontal signal to determine water velocity and direction and a single vertical beam to determine stage. The ADVMs were configured to record and transmit water velocity and stage every 15 minutes to the USGS Web site. The ADVMs were configured to average velocity and stage data for 300 seconds. The velocity data were divided into 10 cells; each cell was 6 feet. The blanking distance at UHAM-CH-DS was 5 feet and the measured zone extended from 30 to 50 feet. The blanking distance at KANS$\mathrm{CH}-\mathrm{DS}$ was 2 feet and the measured zone extended from 45 to 50 feet. The cross-sectional geometry of the transect at each ADVM was defined and surveyed once to develop a stage-area rating. Maintenance and operation of the ADVMs through the period of study followed the recommendations and guidelines contained in Levesque and Oberg (2012) and included watertemperature comparisons and beam checks on a regular basis.

As described in the previous sections of this report, discrete streamflow measurements were made within the chute. Streamflow measurements were used in conjunction with the data collected by the ADVMs to create an index velocity equation. Computing streamflow using the index velocity method differs from the traditional stage-discharge method by separating velocity and area into separate ratings - the index velocity rating and the stage-area rating. The outputs from these ratings, channel-mean velocity $(V)$ and cross-sectional area $(A)$, are factors multiplied together to compute a streamflow. For the index velocity method, $V$ is a function of parameters such as streamwise velocity, stage, cross-stream velocity, and velocity head; and $A$ is a function of stage and cross-section shape (Levesque and Oberg, 2012). The index velocity equation created for each chute was used to compute real-time chute streamflow.

\section{Data Analysis}

Data analysis for this study included two different components as follows: (1) analysis of calculated continuous sediment load based on estimated continuous SSC from a turbidity surrogate and (2) analysis of EWI SSC and loads within each study site. These analysis methods are described in three subsections of the report, including estimation of continuous suspended-sediment loads in the chutes using surrogate relations, comparisons involving continuous suspended-sediment loads in Kansas chute, and comparisons involving discrete suspended-sediment samples.

\section{Estimation of Continuous Suspended-Sediment Loads in the Chutes using Surrogate Relations}

Calculation of continuous sediment loads, as daily and hydrologic-event loads, began with the estimation of continuous SSC from continuous turbidity data that followed USGS guidelines detailed by Rasmussen and others (2009). The calibration dataset, which included the physical samples (discrete EWI and automatic sampling), was quality-assured by comparing the turbidity and streamflow range between the real-time data and the calibration data and by comparing the SSC and turbidity values measured during EWI sampling with the values obtained from the autosampler and continuous water-quality monitor, respectively.

To determine if the suspended-sediment concentrations from an autosampler ( $\mathrm{SSC}_{\text {auto }}$; collected by the programmable pumping sampler) were similar to suspended-sediment concentrations from the discrete equal-width increment samples $\left(\mathrm{SSC}_{\mathrm{EWI}}\right)$, the data were plotted and Pearson's $r$ correlation coefficient (a measurement of the strength of a linear relation ranging from -1 to 1) was calculated. A simple linear regression (SLR) model was developed to predict SSC values that were equivalent to $\mathrm{SSC}_{\mathrm{EWI}}$ using $\mathrm{SSC}_{\text {auto }}$ as the independent variable. Equivalent silt and sand concentrations were then calculated using the autosample SF split. These EWI-equivalent values of SSC, SSiltC, and SSandC were used in the development of the regression relations of SSC to turbidity. Data outliers in the final dataset were evaluated and, if warranted, were omitted from the dataset (Rasmussen and others, 2009).

Surrogate models were developed for SSC as a function of turbidity, and the models were evaluated based on regression statistics and residual diagnostics. Multiple linear regression (MLR) models of SSC were fitted using turbidity with the addition of either streamflow or construction (construction was included as a binary independent variable, coded as "yes" if the data were collected during the construction period and represented by a 1 in the data analysis) as explanatory variables. Candidate MLR models were investigated and compared with their SLR counterparts to obtain the best-fit model for each site. All best-fit models were evaluated using multiple criteria-statistical significance ( $\mathrm{F}$ test for overall model and $t$-tests for individual coefficients), residual plots, normality plots, adjusted R-squared values, and residual standard error values. The MLR models were also evaluated by calculating the variance inflation factor and the model standard percent error of the SLR model (Rasmussen and others, 2009). The variance inflation factor provides a measure of the correlation among explanatory variables and describes how including correlated variables in the model affects the ability of the model to predict SSC. Linear regression models were developed for each of the three chute sampling locations for total SSC and SSiltC. A bias-correction factor was calculated from model residuals following the method of Rasmussen and others (2009). A biascorrection factor was necessary because log-transformed values of SSC were used to fit a power equation, and the residual errors (which have a mean of zero in logarithmic units) do not have a mean of zero after SSC values are back-transformed from log space to arithmetic space; therefore, unless an adjustment is made, a small bias is introduced (Newman, 1993).

The linear regression models were used to predict total SSC and SSiltC every 15 minutes from late March to late October 2012 when turbidity and streamflow data were 
available. The $S S a n d C$ was estimated by subtracting SSiltC from total SSC.

Instantaneous suspended-sediment loads (tons per day; for total suspended load, silt-clay load, and sand load) were calculated from the 15-minute concentration and streamflow data (Lee and others, 2012):

$$
S S L_{\text {in }}=S S C_{\text {in }} \times Q_{\text {in }} \times C
$$

where

$$
\begin{aligned}
S S L_{\text {in }} \quad \begin{array}{l}
\text { is instantaneous suspended-sediment load, in } \\
\text { tons per day; }
\end{array} \\
S S C_{\text {in }} \quad \begin{array}{l}
\text { is instantaneous suspended-sediment } \\
\text { concentration, in milligrams per liter; }
\end{array} \\
Q_{\text {in }} \quad \begin{array}{l}
\text { is instantaneous streamflow, in cubic feet per } \\
\text { second; and }
\end{array} \\
\quad \text { is a constant, 0.0027, for converting the load } \\
\quad \text { units to tons per day. }
\end{aligned}
$$

These instantaneous suspended-sediment loads were then used to estimate total load during the 15-minute period, calculated as follows:

$$
S S L_{15}=S S L_{i n} \times\left(\frac{15}{1440}\right)
$$

where

$$
\begin{aligned}
& S S L_{15} \quad \text { is total suspended-sediment load during the } \\
& \text { 15-minute period, in tons per day; } \\
& S S L_{\text {in }} \quad \text { is instantaneous suspended-sediment load, in } \\
& \text { tons per day. }
\end{aligned}
$$

Total load during 15-minute periods were summed for the 24-hour period to get daily total suspended-sediment load (SSL), silt-clay suspended-sediment load $\left(\mathrm{SSL}_{\text {silt }}\right)$, and sand suspended-sediment load $\left(\mathrm{SSL}_{\text {sand }}\right)$. If continuous turbidity or streamflow data were not available for all 15-minute periods in a day, SSC and instantaneous suspended-sediment load could not be calculated; therefore, a daily load was not estimated even if data were missing for only a small part of the day. Selected flow events, either high flow or stable normal flow, were similarly summarized to estimate the event-total loads for SSL, $\mathrm{SSL}_{\text {silt }}$, and $\mathrm{SSL}_{\text {sand }}$.

\section{Comparisons Involving Continuous Suspended- Sediment Loads in Kansas Chute}

Daily and event-based loads at KANS-CH-US were compared to those at KANS-CH-DS (fig. 2) to determine if geomorphic processes were affecting sediment transport within the chute. Paired $t$-tests were used to determine the significance of differences in daily sediment loads between the two sites; and, from these results, an interpretation was made as to if the chute was generally experiencing net erosion or net deposition during the monitoring period. A second approach used 95-percent confidence intervals to determine if KANS-CH-US daily loads were significantly different than KANS-CH-DS daily loads on a given day to document periods of erosion or deposition within the chute at a daily time scale.

For the daily load comparison, 100 daily loads were randomly selected from KANS-CH-US, and the same daily loads were selected from KANS-CH-DS. Paired $t$-tests (Helsel and Hirsch, 2002) were used to determine if a statistical difference existed between $\mathrm{SSL}, \mathrm{SSL}_{\text {silt }}$, or $\mathrm{SSL}_{\text {sand }}$ at the upstream and downstream sample locations. Random selection of daily loads was used to minimize serial autocorrelation between loads computed from consecutive days, and five replications of the randomized selection followed by hypothesis testing were used to estimate sampling variability of this method. Eventbased loads were also compared between the upstream and downstream monitoring stations in the chute using a paired $t$-test.

A second comparative approach that factored in the uncertainty of the SLR estimates was used to compare daily loads between KANS-CH-US and KANS-CH-DS. Daily loads were evaluated by defining a 95-percent confidence interval around each daily load (Helsel and Hirsch, 2002; Lee and others, 2012; Schaepe and others, 2014) and assessing overlap between the confidence intervals for the day between upstream and downstream load estimates. Confidence intervals are calculated using Student's $t$ distribution critical values and the standard error of the mean (Helsel and Hirsch, 2002). Residual standard error of the regression model was used to calculate confidence intervals around the daily load values. Lee and others (2012) and Schaepe and others (2014) also used the residual standard error of similar regression models to calculate confidence intervals around values predicted using those models. Confidence interval limits were calculated as follows:

$$
\begin{aligned}
& L C L 95=10^{\wedge}\left(\log _{10}\left(S S L_{\text {daily }}\right)-\tau_{(0.025, n-1)} \times R S E\right) \\
& \text { UCL95 }=10^{\wedge}\left(\log _{10}\left(S S L_{\text {daily }}\right)-\tau_{(0.025, n-1)} \times R S E\right)
\end{aligned}
$$

where

LCL95 is the lower confidence limit of total daily load at 95-percent confidence level,

$S S L_{\text {daily }} \quad$ is the estimated daily suspended-sediment load,

$\tau_{(0.025, n-1)}$ is the Student's $\tau$ distribution critical value at $\alpha / 2=0.025$ and $n-1$ degrees of freedom,

$R S E \quad$ is the residual standard error of the regression model (table 2), and

UCL95 is the upper confidence limit of total daily load at 95-percent confidence level.

Use of this linear regression-based method carries an implicit assumption that no error is associated with streamflow values used to calculate the loads. The resulting daily confidence intervals around the load estimate were evaluated for overlap between KANS-CH-US and KANS-CH-DS. If the confidence intervals did not overlap, then the loads were statistically different for that day and represented measurable net erosion or deposition within the Kansas chute. 


\section{Comparisons Involving Discrete Suspended- Sediment Samples}

Analysis of differences in EWI SSC and loads between transects within each study site used methods similar to those completed by Woodward and Rus (2011) and used Student's $t$ distribution because there were only seven sampling events. The distribution of the $t$ statistic is similar to a normal distribution but presumes more variance as a function of the sample size; therefore, the $t$ statistic is preferable for small sample sizes such as were available in this study (Ott and Longnecker, 2001). Paired $t$-tests with unequal variance and a 95 -percent significance level (alpha equals 0.05 ) were used to test for a difference between two subsets of samples. Paired $t$-tests can detect smaller differences by removing extraneous intersite variability (such as might be caused by varying streamflow conditions) from the comparisons. Samples were paired by the day of sample collection. For each test result reported, the corresponding $p$-value also is reported. The $p$-value represents the probability that the statistical test results, or more extreme values, could have occurred if the null hypothesis was true. In the comparisons, the null hypothesis is that the two samples were drawn from populations that are not different. A $p$-value smaller than the alpha level (or rejection level) of 0.05 indicates that the statistical test outcome provides evidence that the null hypothesis is false; results are rare where the null hypothesis is true. If the resulting $p$-value is less than 0.05 , the test statistic is significant, meaning that the null hypothesis (the two samples being the same) is rejected and the two samples are declared with 95-percent confidence to be significantly different. Paired $t$-tests of loads, SSC, and turbidity values from EWI samples were used to answer three questions as follows: (1) does the chute sediment load produce a measurable difference in the main-channel sediment load, (2) do the chute sediment characteristics change from upstream to downstream, and (3) are the chute upstream sediment characteristics different than the Missouri River upstream sediment characteristics. In addition, 2008 EWI sample data (Woodward and Rus, 2011) were included in the analysis when applicable.

\section{Quality Control}

Quality-control data (three pairs of EWI replicate samples total from all sites) were analyzed for precision, which was measured as the relative percent difference between the original sample and the replicate sample ([original sample - replicate $] /[($ original sample + replicate $) / 2] * 100)$. This analysis of sequential replicates indicates how imprecise the overall sampling and laboratory analysis were, even with the small number of quality-control samples.

Turbidity values exceeded the maximum sensor limit of 1,000 FNU (as specified by the manufacturer) at the KANS-CH-US and KANS-CH-DS sites. The sensors appeared to operate adequately at the levels that were exceeded (1,038 FNU at KANS-CH-US and 1,000 FNU at KANS-CH-DS); therefore, the values were not censored in the analyses. Furthermore, these values represent less than 0.17 percent of the stream volume monitored during the study and are not expected to significantly affect the load comparisons.

\section{Sediment Loads in the Chutes}

Daily suspended-sediment loads were estimated based on surrogate relations of SSC with turbidity (and streamflow at one transect). The statistical model-calibration dataset of EWI and autosampler data were evaluated and determined to be adequate for predicting SSC from turbidity. A linear regression was used to estimate EWI-equivalent SSC from autosampler SSC before using the model-calibration dataset to determine the best regression model of the turbidity and SSC relation. Construction period was considered for inclusion as a binary independent variable in the relation between turbidity and SSC but was not included in any of the best-fit models; therefore, the conclusion was made that construction did not strongly affect the relation between turbidity and SSC. Daily suspended-sediment loads were significantly reduced by the closure of Upper Hamburg chute inlet structure. Daily suspended-sediment loads were not significantly different between upstream and downstream sites within Kansas chute, as indicated using paired $t$-tests, and most individual daily loads were not significantly different between upstream and downstream sites, as indicated by overlap in confidence intervals.

\section{Surrogate Relations in the Chutes}

Evaluation of the model-calibration datasets used in developing surrogate relations between turbidity and SSC at UHAM-CH-DS, KANS-CH-US, and KANS-CH-DS determined that the model-calibration datasets were adequate. The model-calibration datasets consisted of the SSC results from physical samples (discrete EWI and automatic sampling) and associated turbidity values. Turbidity had been measured along with the EWI using an aliquot from the churn, and turbidity values also were recorded by the continuous water-quality monitor during the time of EWI or autosampler sampling. Turbidity values measured from the EWI samples were compared with the corresponding turbidity values from the continuous water-quality monitor (one single reading during the EWI mean sample time) using paired $t$-tests. The results did not determine differences in the values $(n=21$ and $p=0.7182$ ), which indicate that the continuous water-quality monitor values measured near the bank are representative of the values from the entire transect and can be used for regression equation development. Strong linear correlation exists between SSC and SSiltC from EWI samples and concurrent samples collected by an autosampler as indicated by Pearson's $\mathrm{r}$ value of 0.93 ( $n=7$ from all three sites combined), which was the same for SSC and SSiltC correlation. In addition, 
slopes in both linear regression models (again, $n=7$ from all three sites combined) for SSC and SSiltC from EWI samples and concurrent samples collected by an autosampler were near one; however, no correlation was evident in the SF split (Pearson's $r$ value of $-0.06, n=7$ from all three sites combined) between the EWI and autosamples. Correlation between SSandC in EWI samples and concurrent samples collected by an autosampler was low with a Pearson's r value of only 0.07 ( $n=7$ from all three sites combined). The low correlation in the SF split and SSandC values may be explained by the majority of the sediment being silt-sized or finer; therefore, linear correlation in the coarser fractions was obscured by measurement imprecision. This imprecision may have been the result of a depth dependence in the concentration of larger particles like sand (Julien, 2010) that was not captured from the fixed-point sampling location of the autosampler. The low correlation may also be the result of inefficient sample splitting of the sand-size particles in the composite EWI sample using a churn splitter (Capel and Larson, 1996). Based on the results and considerations, no further steps were made to develop a surrogate relation of $S S a n d C$ to turbidity because a large number of samples in the calibration dataset were from autosamplers; therefore, any relation between turbidity and $S S a n d C$ would likely be poor. Instead, SSandC was estimated as SSC minus SSiltC. Physical samples collected by EWI sampling or autosamplers represented a substantial part of the ranges of streamflow and turbidity observed in the chutes during the summer of 2012 (figs. 5, 6; table 1). The greatest difference in data ranges between the model-calibration dataset and the time-series dataset is in the maximum turbidity at Kansas chute. The maximum turbidity during a physical sample at KANS-CH-US was only 379 FNU, and the maximum turbidity from the time-series data was 1,038 FNU (table 1); therefore, the calibration dataset from KANS-CHUS does not fully represent the range of turbidity. During the study period, however, only 8 percent of the total flow volume was when FNU was greater than 310 . In addition, the calibration dataset at KANS-CH-US and KANS-CH-DS does not

Table 1. Summary of the model-calibration dataset and the time-series dataset at Upper Hamburg chute and Kansas chute.

[mg/L, milligrams per liter; FNU, formazin nephelometric units; ft³/s, cubic foot per second; UHAM-CH-DS, Upper Hamburg chute downstream; KANS-CH-US, Kansas chute upstream; KANS-CH-DS, Kansas chute downstream]

\begin{tabular}{|c|c|c|c|c|c|}
\hline \multirow{2}{*}{ Summary statistic } & \multirow{2}{*}{$\begin{array}{c}\text { Suspended-sediment } \\
\text { concentration (mg/L) } \\
\begin{array}{c}\text { Model-calibration } \\
\text { dataset }\end{array}\end{array}$} & \multicolumn{2}{|c|}{ Turbidity (FNU) } & \multicolumn{2}{|c|}{ Streamflow $\left(\mathrm{ft}^{3} / \mathrm{s}\right)$} \\
\hline & & $\begin{array}{c}\text { Model-calibration } \\
\text { dataset }\end{array}$ & $\begin{array}{c}\text { Time-series } \\
\text { dataset }\end{array}$ & $\begin{array}{c}\text { Model-calibration } \\
\text { dataset }\end{array}$ & $\begin{array}{c}\text { Time-series } \\
\text { dataset }\end{array}$ \\
\hline \multicolumn{6}{|c|}{ UHAM-CH-DS } \\
\hline \multicolumn{6}{|c|}{34 samples and 16,737 15-minute values } \\
\hline Minimum & 32 & 14 & 15 & 873 & 395 \\
\hline Mean & 91 & 42 & 57 & 1,993 & 2,719 \\
\hline Median & 57 & 34 & 34 & 1,270 & 1,380 \\
\hline Standard deviation & 112 & 29 & 58 & 1,688 & 1,842 \\
\hline \multicolumn{6}{|c|}{ KANS-CH-US } \\
\hline \multicolumn{6}{|c|}{31 samples and 18,896 15-minute values } \\
\hline Mean & 320 & 112 & 65 & 6,800 & 3,659 \\
\hline Median & 291 & 93 & 34 & 7,200 & 1,967 \\
\hline Standard deviation & 209 & 82 & 88 & 3,691 & 2,781 \\
\hline \multicolumn{6}{|c|}{ KANS-CH-DS } \\
\hline \multicolumn{6}{|c|}{34 samples and 20,623 15-minute values } \\
\hline Minimum & 55 & 31 & 21 & 1,669 & 960 \\
\hline Maximum & 3,190 & 940 & ${ }^{1} 1,000$ & 18,844 & 19,186 \\
\hline Mean & 489 & 193 & 78 & 6,603 & 3,659 \\
\hline Median & 110 & 71 & 51 & 1,996 & 1,967 \\
\hline
\end{tabular}

${ }^{1}$ Value at or above the manufacturer-specified sensor limit for the turbidity probe. 

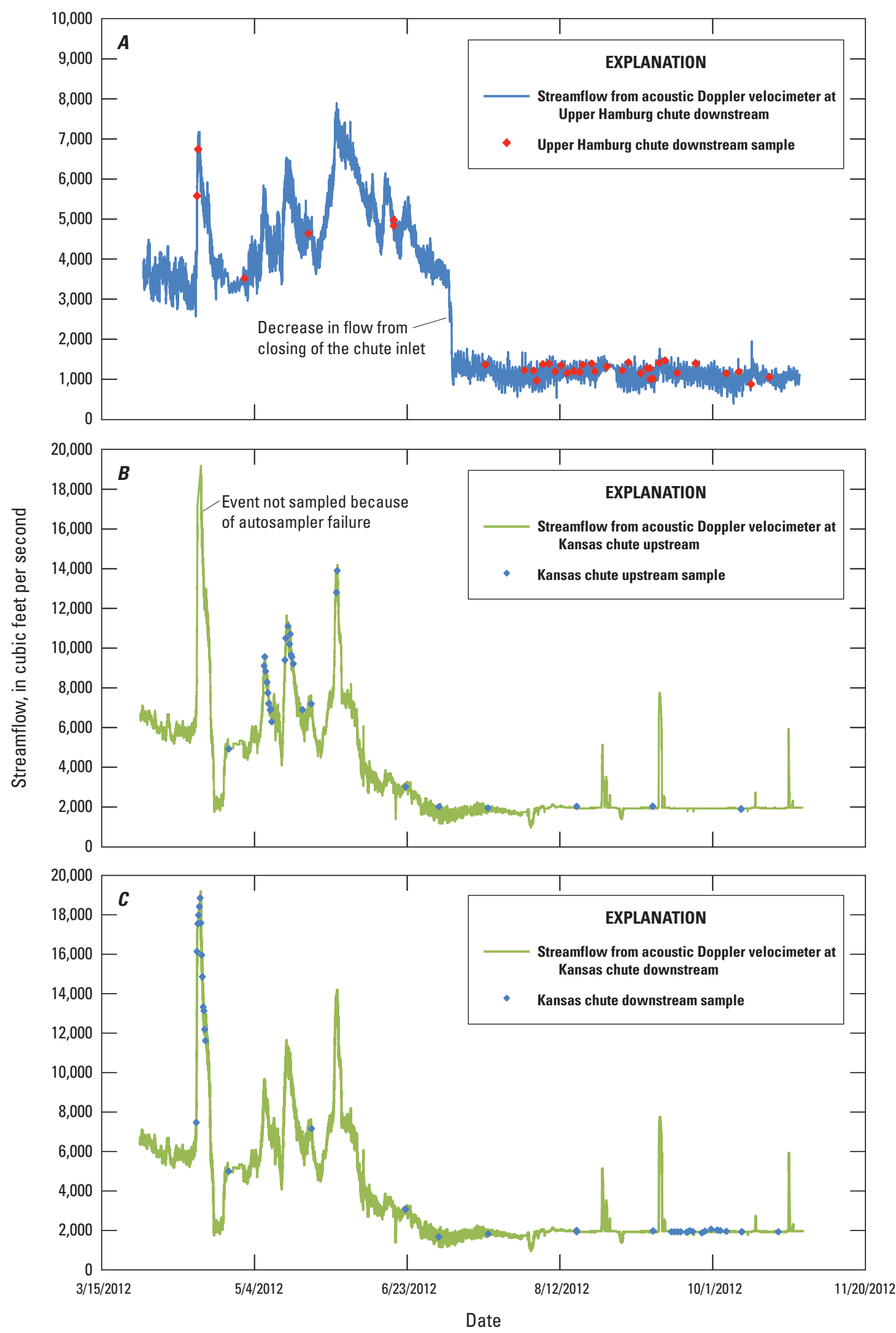

Figure 5. Streamflow and dates of physical samples, April through October 2012 at $(A)$ Upper Hamburg chute downstream, $(B)$ Kansas chute upstream, and $(C)$ Kansas chute downstream. 


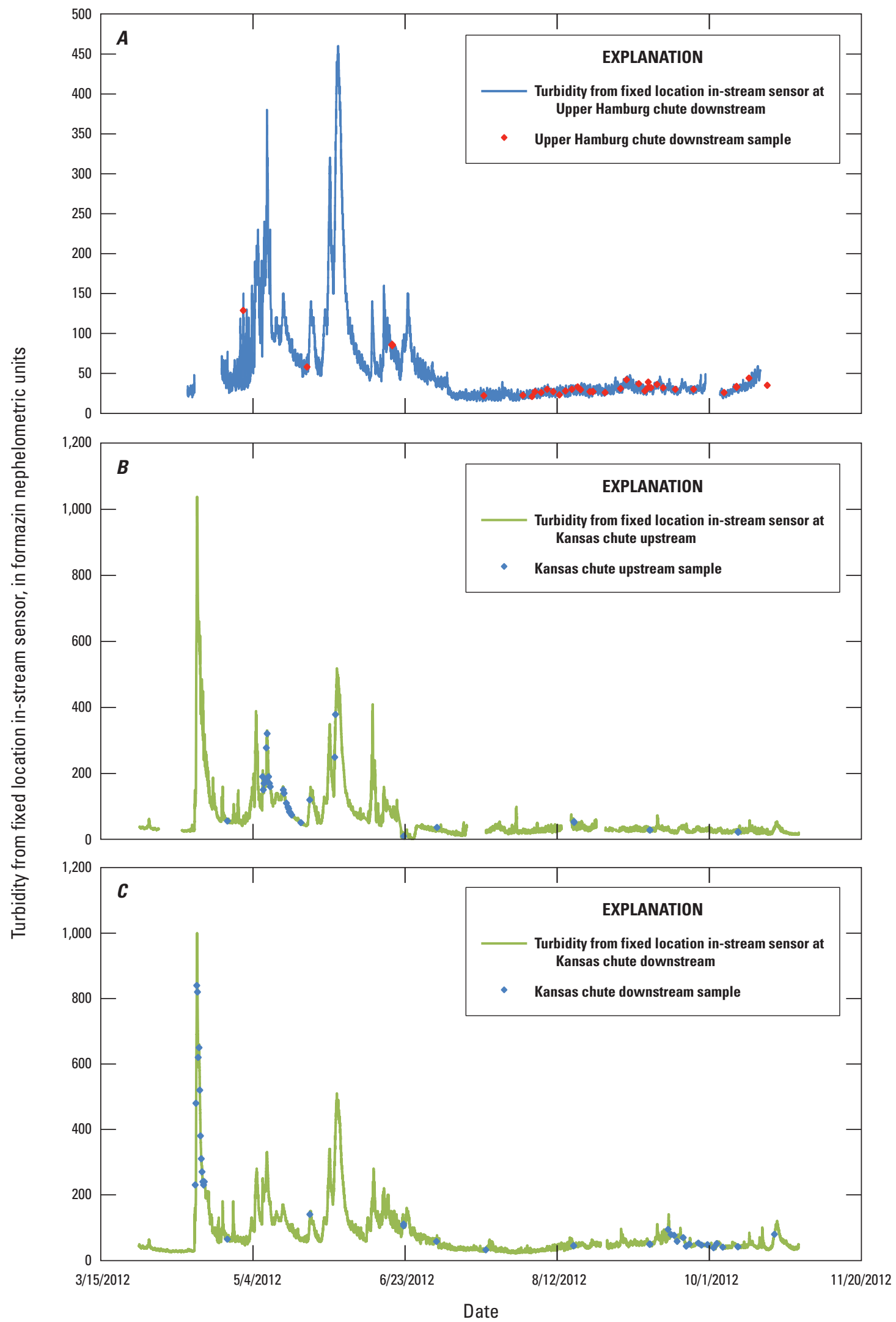

Figure 6. Fixed location in-stream turbidity and dates of physical samples, April through 0ctober 2012 at (A) Upper Hamburg chute downstream, (B) Kansas chute upstream, and $(C)$ Kansas chute downstream. 
represent the range of low streamflow. For KANS-CH-US and KANS-CH-DS, the minimum streamflow recorded in the time-series dataset was 960 cubic feet per second $\left(\mathrm{ft}^{3} / \mathrm{s}\right)$, but the minimum streamflow during a physical sample was 1,880 and 1,669 $\mathrm{ft}^{3} / \mathrm{s}$, respectively (table 1). During the study period, however, only 1.7 percent of total flow was when streamflow was less than $1,669 \mathrm{ft}^{3} / \mathrm{s}$.

The hydrographs for each chute (fig. 5) show that only a few flow events occurred during the study period. The hydrograph at Upper Hamburg chute shows the substantial decrease in streamflow because of the closing of the chute inlet in early July. Samples collected at Upper Hamburg chute before the closing of the inlet were mostly monthly EWI samples because of autosampler failure; therefore, data from Upper Hamburg chute are more representative of the low-flow condition. Similarly, the initial high-flow event, April 15, 2012, at Kansas chute was not sampled at KANS-CH-US because of autosampler failure; however, several autosampler samples were collected and analyzed during the high-flow event at KANS-CH-DS. Additional samples were analyzed from KANS-CH-US during the three smaller events on May 7, 14, and 30,2012. Samples adequately represented the range in streamflow and turbidity throughout the sampling period (table 1); however, the samples did not represent the same high-flow events at each site, and the distribution of samples was uneven across the quantiles of streamflow frequency.

Results for total SSC were evaluated and some concentrations were deemed erroneous. Erroneous total SSC generally either did not agree with EWI and real-time turbidity values or had an unrealistically high proportion of sand (implying that the sample may have been contaminated by streambed sediments). Samples that were deemed erroneous and removed from the calibration dataset before fitting the final regression models are shown in the plot of turbidity and SSC (fig. 7).

The last step before developing best-fit models for estimating SSC from turbidity was to estimate EWI-equivalent SSC from autosampler SSC. Because a significant linear correlation was determined between autosampler SSC and EWI SSC (Pearson's $r$ of 0.93) a linear regression equation was used to estimate EWI-equivalent SSC. The SLR developed from seven sets of paired EWI samples and autosamples combined from all three sites is as follows:

$$
\text { Estimated } S S C_{E W I}=S S C_{\text {auto }} \times 0.8834+11.3738
$$

where

Estimated $S S C_{E W I}$ is the EWI-equivalent suspended-sediment concentration;

$S_{S S}$ auto is suspended-sediment concentration from an autosampler.

The regression equation had a large residual standard error of 30.03 milligrams per liter because of the small sample size but a good adjusted R-squared value of 0.8463 . Because no correlation was indicated between EWI and autosampler values of SF split, the estimated EWI SSC was used with the autosampler SF split to estimate SSiltC and SSandC.

After the model-calibration dataset had been fully evaluated, the EWI SSC with the estimated EWI SSC and the EWI SSiltC with the estimated EWI SSiltC were used with the continuous turbidity data to develop best-fit SLR or MLR models. At all sites, the best-fit models included the base10 logarithm of concentration and turbidity, and at Kansas chute upstream, the base-10 logarithm of streamflow was also included in the best-fit models (table 2). At KANS-CH-US, the base-10 logarithm of streamflow was included in the best-fit models because the variance inflation factor between turbidity and streamflow was acceptable (variance inflation factor equals 2.48; variance inflation factor less than 10 indicates that the variables are not multicollinear [Rasmussen and others, 2009]). Also, the base-10 logarithm of streamflow was included in the best-fit models at KANS-CH-US because the standard percent error of the SLR models, derived as a percentage of the model standard error, was 34.4852.62 percent; if greater than 20 percent then the addition of

Table 2. Regression equations for estimation of suspended-sediment concentrations in two sediment size classes.

$\left[n\right.$, number of samples; RSE, residual standard error; $\mathrm{mg} / \mathrm{L}$, milligram per liter; $R^{2}$, coefficient of determination; MSPE, model standard percent error; UHAM-CH-DS, Upper Hamburg chute downstream; SSC, suspended-sediment concentration; Turb, turbidity in formazin nephelometric units; SSiltC, suspended-silt concentration; KANS-CH-US, Kansas chute upstream; $Q$, streamflow; KANS-CH-DS, Kansas chute downstream]

\begin{tabular}{|c|c|c|c|c|c|c|}
\hline Site identifier & Equation & $n$ & $\begin{array}{c}R S E, \text { in } \\
\log (\mathrm{mg} / \mathrm{L}) \\
\text { units }\end{array}$ & $\begin{array}{c}\text { Adjusted } \boldsymbol{R}^{2} \\
\text { (dimensionless) }\end{array}$ & $\begin{array}{c}\text { Bias } \\
\text { correction } \\
\text { factor }\end{array}$ & MSPE \\
\hline \multirow[t]{2}{*}{ UHAM-CH-DS } & $\log _{10}(\mathrm{SSC})=1.0132 \log _{10}($ Turb $)+0.2838$ & 32 & 0.092 & 0.78 & 1.02 & $+23.6,-19.1$ \\
\hline & $\log _{10}($ SSiltC $)=0.9088 \log _{10}($ Turb $)+0.4229$ & 31 & 0.085 & 0.69 & 1.02 & $+21.6,-17.8$ \\
\hline KANS-CH-US & $\log _{10}(\mathrm{SSC})=0.4524 \log _{10}($ Turb $)+0.6217 \log _{10}(Q)-0.8658$ & 27 & 0.130 & 0.87 & 1.04 & $+34.9,-25.9$ \\
\hline \multirow[t]{2}{*}{ KANS-CH-DS } & $\log _{10}(\mathrm{SSC})=1.1317 \log _{10}($ Turb $)+0.0120$ & 33 & 0.110 & 0.95 & 1.03 & $+28.8,-22.4$ \\
\hline & $\log _{10}($ SSiltC $)=1.1351 \log _{10}($ Turb $)+0.0059$ & 33 & 0.110 & 0.95 & 1.03 & $+28.8,-22.4$ \\
\hline
\end{tabular}



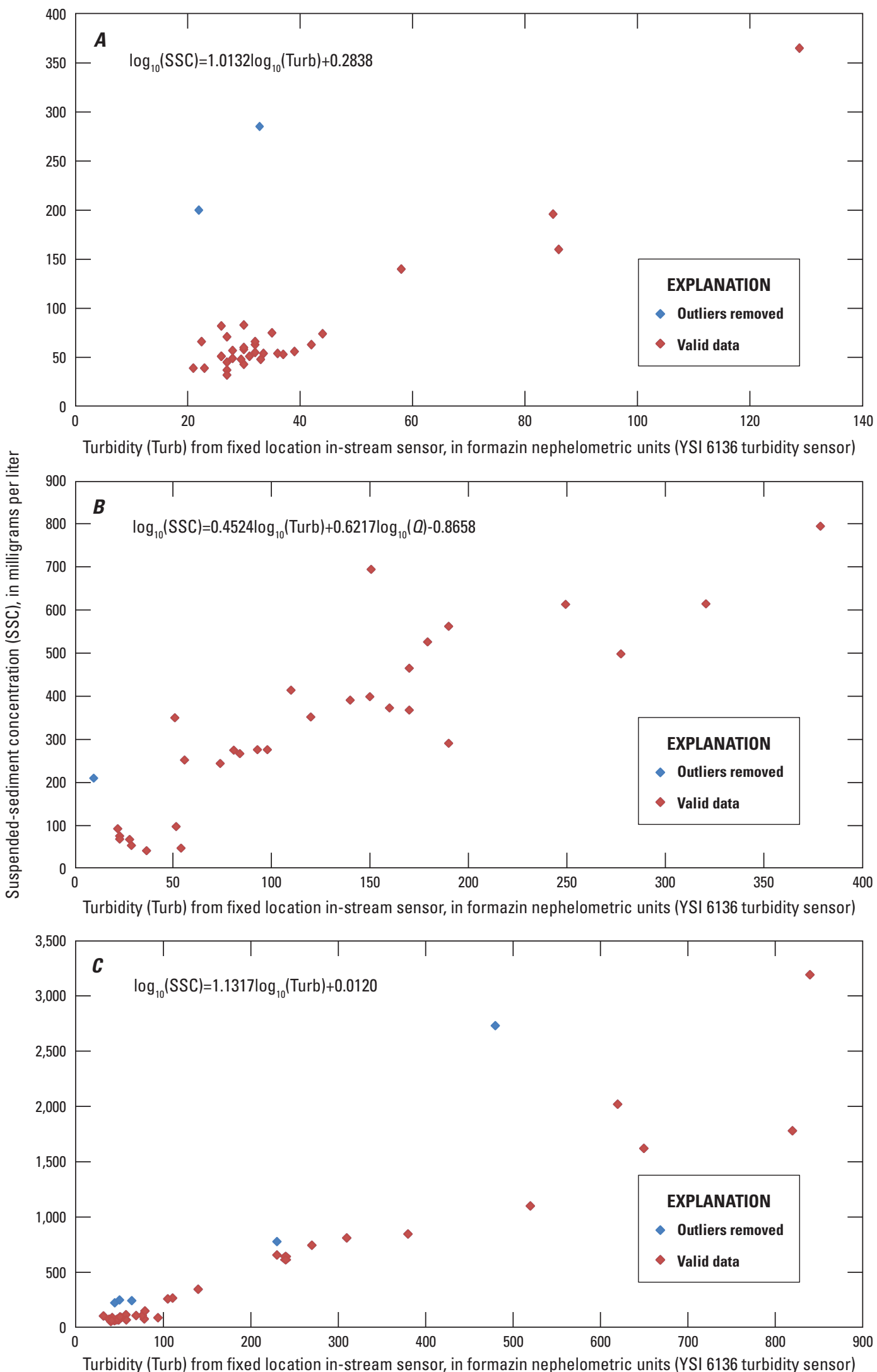

Figure 7. Turbidity in relation to total suspended-sediment concentration, including outliers excluded from regression analysis of data collected at $(A)$ Upper Hamburg chute downstream, $(B)$ Kansas chute upstream, and $(C)$ Kansas chute downstream. 
an additional explanatory variable is reasonable (Rasmussen and others, 2009). The selected models had high R-squared values (0.69-0.95) and model standard percent errors of 35 percent or less between turbidity and SSC (and streamflow at KANS-CH-US; table 2). The values indicate that turbidity typically predicted SSC within 35 percent at these study sites. Because of the number of samples, separate models could not be developed for construction and nonconstruction periods. Construction period was considered for inclusion as a binary independent variable in the relations between turbidity and SSC but was not included in any of the best-fit models. The result indicates that any sediment-transport effect from construction was already represented by changes in the turbidity or streamflow. Bias-correction factors were calculated based on model residuals as described in Rasmussen and others (2009), and the back-transformed concentration estimate was multiplied by the bias-correction factor, which ranged from 1.02 to 1.04 (table 2).

\section{Suspended-Sediment Load Estimates}

Suspended-sediments loads were estimated using computed SSC values (calculated from the developed models), continuous turbidity data (March 27, 2012, through October 31, 2012), and continuous streamflow data. Instantaneous loads were calculated from SSC and SSiltC and were used to estimate total SSL and $\mathrm{SSL}_{\text {silt }}$ for each 15-minute period. Daily total SSL and $\mathrm{SSL}_{\text {silt }}$ were estimated by totaling all 15-minute loads for the day (table 3, at the back of this report). Sand load was calculated using the same method, except SSandC was estimated as the difference between SSC and SSiltC. The sum of the daily silt and sand load rarely is greater than the daily total load because of rounding (table 3 ). As expected, the estimated daily loads indicated a substantial drop in sediment transport at Upper Hamburg chute following the closure of the inlet structure on July 6, 2012. For the two Kansas chute sites, hydrologic event loads (table 4 ) were also calculated by summing the 15-minute loads for the duration of events selected on the basis of the hydrograph (figure 5, $B$ and $C$ ). Loads for the rising and falling limbs of the hydrograph of the selected hydrologic events also were calculated.

\section{Comparisons Involving Suspended-Sediment Loads in Kansas Chute}

Suspended-sediment loads were compared between upstream and downstream transects to determine if a pattern or trend existed between sites during high- or low-flow events. Data collected during high-flow events indicated no consistent pattern of higher loads at KANS-CH-DS when compared to KANS-CH-US, as might be expected (table 4). During a high-flow event, scour erosion would be expected during the rise (and possibly the fall) of the hydrograph; bank erosion and bed deposition would be expected during the fall of the hydrograph. Data collected during the rise of the hydrograph and data collected during the fall of the hydrograph during highflow events indicate no consistent patterns (table 4). During a low-flow event, little scour or deposition would be expected. During low-flow events, an aggradational pattern of higher loads at KANS-CH-US as compared to loads at KANS-CHDS was observed for the sand-size fraction for all four events. If the chute was aggrading (as might be expected based on the physical characteristics of chutes to create complex, low velocity SWH) net deposition is expected of the coarsest size fraction of the suspended load reflected in a measurable difference in $\mathrm{SSL}_{\text {sand }}$ between the chute inlet and outlet for some part of the event hydrograph (table 4).

The results of paired $t$-tests indicate no difference between KANS-CH-US and KANS-CH-DS in five different randomly selected subsets of 100 daily values (actual $n$ ranged from 80 to 85 once "no data" values were removed) of total SSL ( $p$ values from 0.2189 to 0.9837 ) or $\mathrm{SSL}_{\text {silt }}$ ( $p$ values from 0.1762 to 0.8765 ). Two of the five randomly selected subsets of 100 daily $\mathrm{SSL}_{\text {sand }}$ did indicate significant differences between upstream and downstream, with an estimated difference of 39-52 tons, but the test results for the other three subsets had $p$ values from 0.1029 to 0.1564 . These results indicate that the chute sediment transport was variable; therefore, daily load comparisons on a smaller time scale than the 7-month monitoring period, such as daily, might lead to a better understanding of sediment transport processes within the chute.

Confidence intervals were calculated around each daily total, silt, and sand load estimate at KANS-CH-US and KANS-CH-DS as described by Lee and others (2012) and Schaepe and others (2014) using the residual standard error of each model. Most daily loads indicate overlap in the confidence intervals for the upstream and downstream stations (table 5, at the back of this report). Confidence intervals did not incorporate the uncertainty in the estimate of streamflow. Confidence intervals at the 95-percent level ranged from (difference between the upper and lower limit) 139 to 66,390 tons per day for total load, from 128 to 65,130 tons per day for silt load, and from 4 to 1,456 tons per day for sand load.

These confidence intervals indicate that most daily loads are not significantly different between upstream and downstream. Confidence intervals for SSL and $\mathrm{SSL}_{\text {silt }}$ indicate that significant erosion only occurred 4 days during the sampling period (June 22, 2012, through June 25, 2012) and that significant deposition only occurred 4 days during the sampling period (April 1, 2012, and April 11, 2012, through April 13, 2012). When confidence intervals for $\mathrm{SSL}_{\text {sand }}$ were compared, significant deposition was commonly indicated (table 5).

A plot of the difference (KANS-CH-US and KANSCH-DS) in the total suspended-load estimate (fig. 8) shows the dynamic nature of sediment transport within the chute. Although differences outside of the confidence intervals were only identified for two 4-day periods listed earlier, the pattern of differences demonstrated in the plot is still informative. Before the first high-flow event on April 15, 2012, deposition was occurring, and then approximately 31,000 tons (during 2 days) of sediment eroded from the chute during the peak 


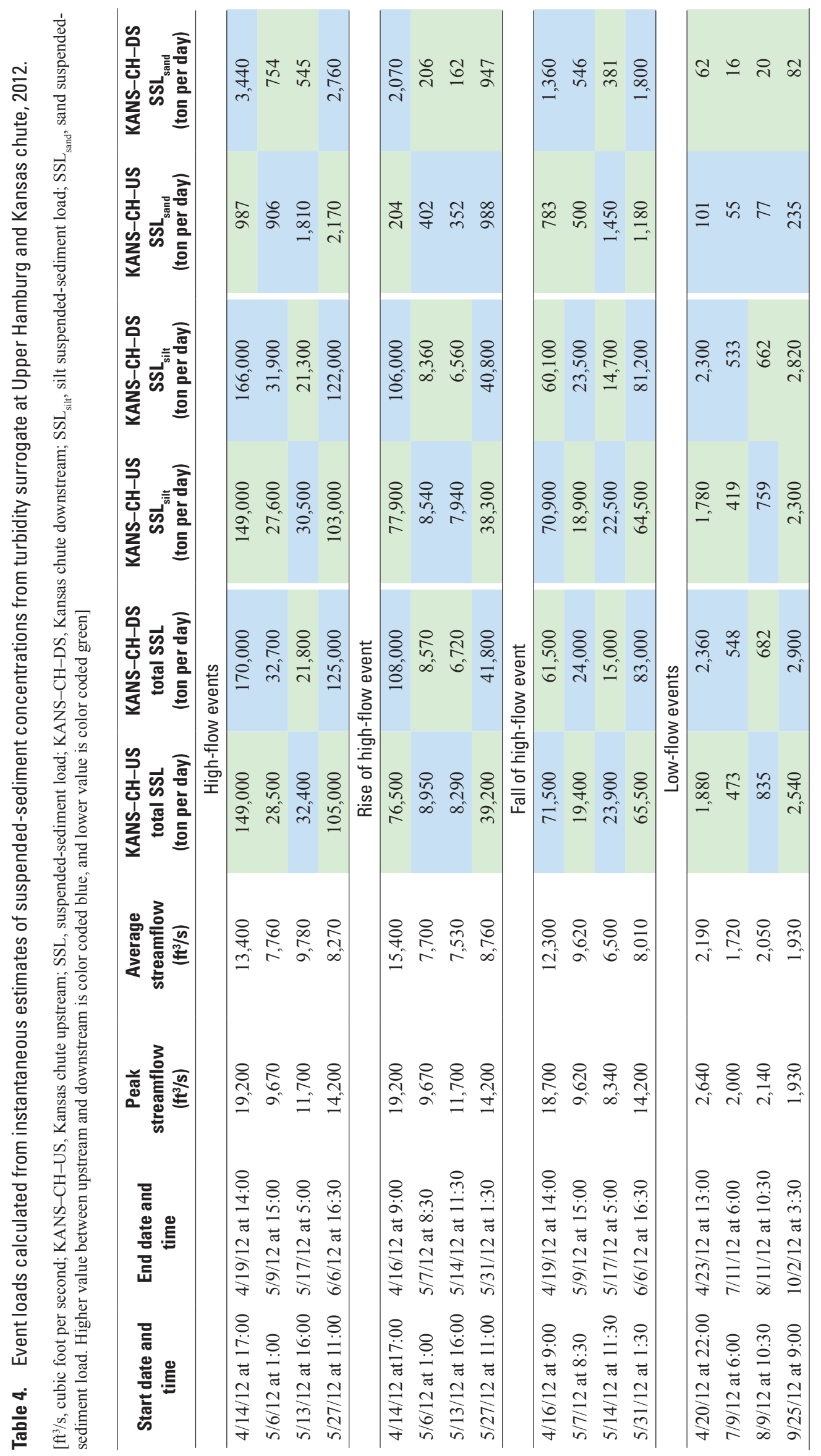


flows, followed by progressively decreasing deposition during 3 days of the falling hydrograph, and finally several days of erosion from the chute again as the hydrograph settled out to a low-flow period before the next event. Examination of the other three high-flow events in the early summer of 2012 indicates that during two of the three events, the chute was eroding; however, during the May 14, 2012, high-flow event, deposition was estimated to have been uninterrupted. In addition, the data indicate that net deposition was typical until shortly after construction activities began, when results indicate net erosion became dominant during a generally receding hydrograph (fig. 8). Net erosion was estimated for an extended period of time even after the completion of construction; likely the effect of the newly installed spur dikes.

Suspended-sediment loads for the total and silt-clay size fractions were successfully estimated for the three continuous water-quality monitoring locations based on concentrations in EWI and automatic samples, a surrogate relation with turbidity, and streamflow within the chute (at KANS-CH-US). Sand load was not well estimated using autosamplers and turbidity surrogate relations for these sites. Paired $t$-tests were not the best statistical analysis for differences between upstream and downstream sediment load at Kansas chute because of the dynamic nature of sediment transport, which required analysis at a smaller time scale such as daily instead of during the entire season. Calculated confidence intervals for each daily load estimate were used to determine if the difference between upstream and downstream loads differed significantly at the daily time scale. The confidence intervals, however, did not incorporate the error in the estimate of streamflow used in calculating the loads. Confidence intervals indicated that most daily load estimates were not significantly different between KANS-CH-US and KANS-CH-DS. A review of the differences between the upstream and downstream loads indicated that when large erosion events were occurring, the hydrograph peaked or a construction period was ongoing within the chute. Similarly, when the difference in the load estimates between upstream and downstream chute sites indicated a large deposition event, there was an associated change in the hydrograph. The comparison of daily load values estimated from turbidity surrogates for upstream and downstream chute sites documents the dynamic nature of sediment transport within the chute. Understanding loads at this daily time scale is not possible with discrete suspended-sediment sampling alone.

\section{Sediment Transport Characteristics Within and Adjacent to the Chutes}

The final analysis completed for this study was a comparison of discrete or EWI sediment data collected within the chutes and within the main channel of the Missouri River upstream and downstream from the chutes. These analyses are similar to those reported by Woodward and Rus (2011). Paired $t$-tests were used to evaluate the difference in sediment concentrations and loads between sampling locations or transects (table 6). Comparisons made included (1) Missouri River upstream to chute upstream to understand how the chute inlet structures affect sediment entering the chute; (2) chute upstream to chute downstream to identify any change in sediment characteristics within the chutes; (3) Missouri River upstream to Missouri River downstream to determine if the chutes had an overall effect on sediment characteristics in the main channel; (4) Missouri River upstream to chute downstream to determine if sediment concentrations at the downstream chute transect are significantly higher or lower than concentrations in the Missouri River upstream from the chute, which indicates that the chute is adding sediment to the main channel or the chute is diluting the sediment within the main channel. All four of these comparisons were made for each studied chute separately, and an additional set of comparisons was completed with the dataset that included data from both chutes together. Some of these same comparisons were also made with 2008 data included (comparison 3 and 4 described earlier; table 6).

The interpretive power of these comparisons was constrained by small sample sizes in relation to the inherent variability of suspended-sediment sampling as well as the anticipated small sediment-transport contributions from the chute relative to the sediment transport of the Missouri River main channel. Three replicate samples, two from the Missouri River main channel and one from a chute, were collected during the study to better understand sampling variability (data are in appendix 1). Laboratory results for these samples were analyzed by computing the relative percent difference between the original sample and the replicate sample. For SSC, the relative percent difference values were 4.6, 22, and 9.7 percent. The grain-size distribution, as percentage finer than sand, had relative percent difference values of 0 and 9.6 percent (no data for the KANS-MR-US sample pair from July 19, 2012).

Concentrations were compared between Missouri River upstream and the chute upstream to understand how the chute inlet structures affect sediment entering the chute (table 6). Sampling was not completed upstream within Upper Hamburg chute; therefore, the comparison was only made for Kansas chute. Total SSC was significantly greater in the Missouri River main channel upstream from the chute inlet than within the chute at KANS-CH-US transect ( $p=0.0393$ and $n=6)$; with a mean difference of 120 milligrams per liter (table 6). Differences in silt-clay and sand concentrations could not be evaluated because several of the Missouri River samples at Kansas chute were analyzed only for SSC and SF-split data were not available. Similar sampling in 2008 indicated that the inlet structures at Upper Hamburg chute and Glovers chute (not shown) reduced the total SSC and the SSandC entering the chutes but did not significantly affect the silt concentration (Woodward and Rus, 2011).

Comparisons among concentration, load, and turbidity from the chute upstream transect to the chute downstream transect indicated no significant difference (table 6). The sample size, however, was small after erroneous sample data had 


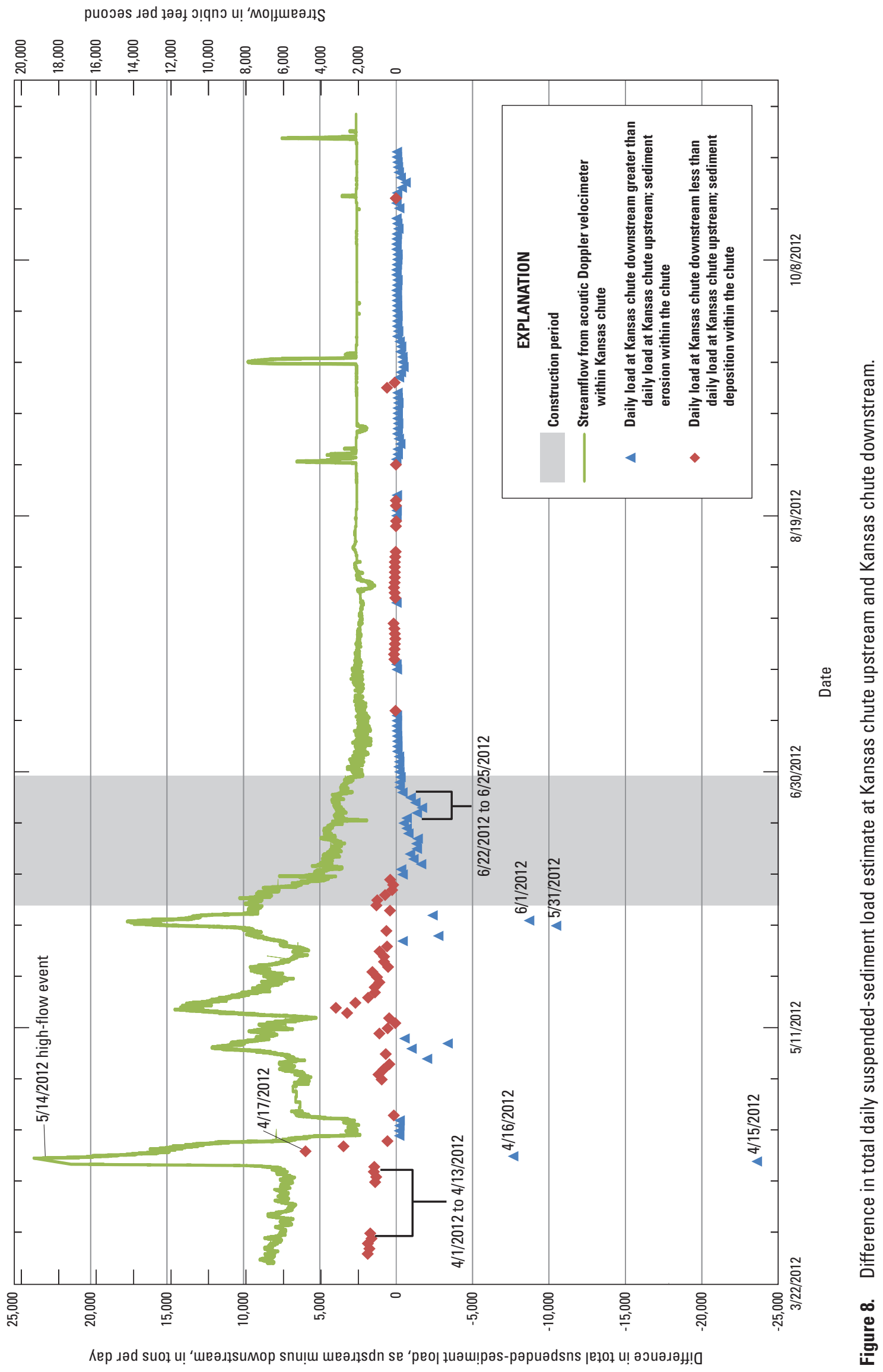




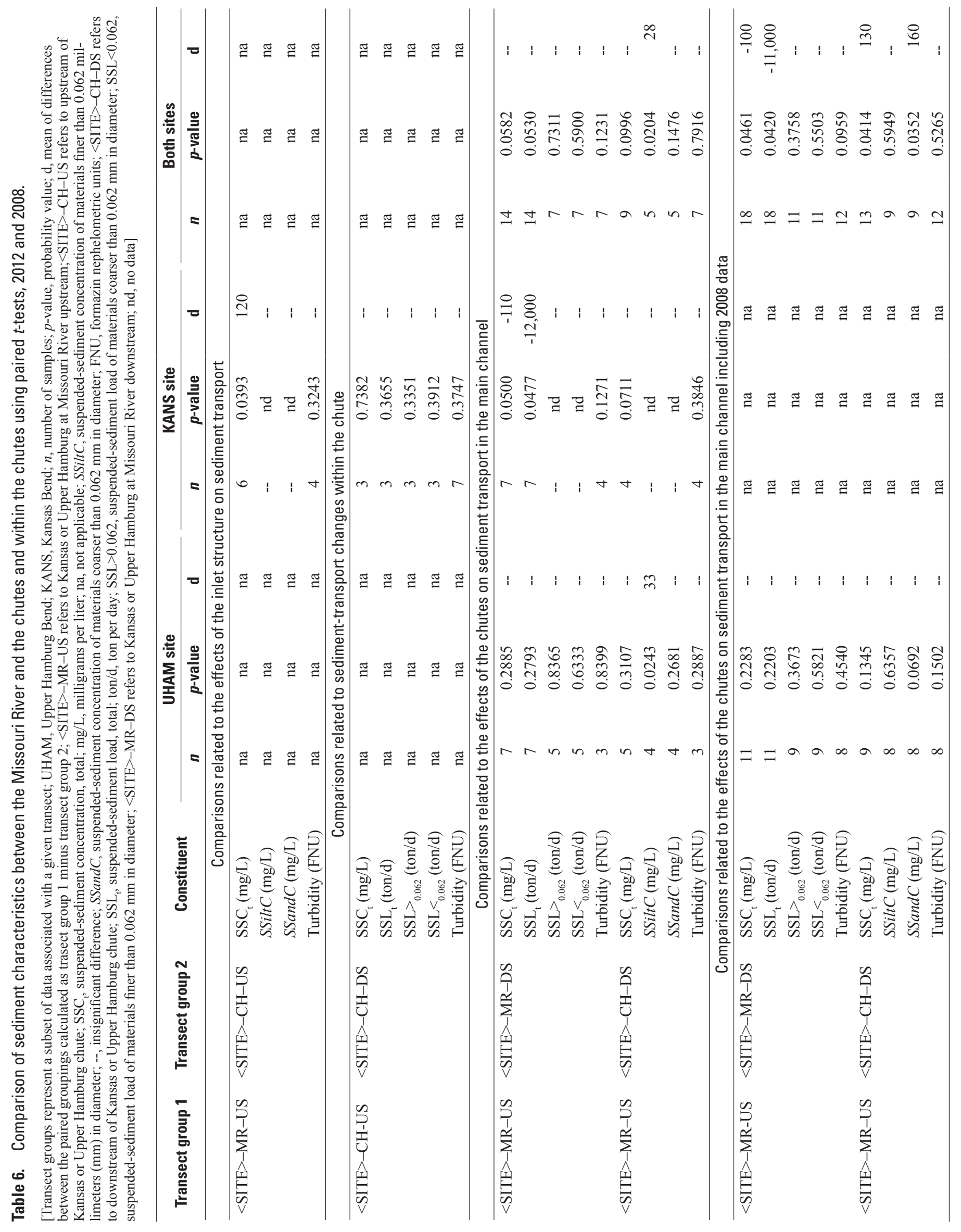


been removed from the dataset, which limited the power of the analysis to detect differences. Data were not collected from the upstream transect within Upper Hamburg chute; therefore, the comparison was only made for Kansas chute.

Concentrations and loads from the Missouri River upstream from the chutes and Missouri River downstream from the chutes were compared. If concentrations and loads were significantly different between the two transects, then the chutes probably are affecting sediment transport within the Missouri River main channel. If concentrations and loads were not significantly different between the two transects, then the chute contributions to the main channel are not detectable. Comparisons of concentrations and loads from the Missouri River upstream transect with those of the Missouri River downstream transect indicated no statistical difference for the Upper Hamburg study site (table 6). The total SSC and the total SSL, however, were significantly different between the Missouri River upstream transect and the Missouri River downstream transect at Kansas chute $(n=7$ and $p=0.0500$ and 0.0477 , respectively; table 6). The test indicated that the Missouri River downstream had SSC approximately 110 milligrams per liter higher and SSL approximately

12,000 tons per day greater than upstream from the chute inlet (table 6), which indicates a large amount of sediment delivery or resuspension to the Missouri River between the two sampling transects when samples were collected, possibly originating in the chute. The significant difference between upstream and downstream total SSC and total SSL in the main channel is possible evidence of induced erosion from construction-related disturbance, natural erosion along either the main channel or in the chute, or measurement error (mean sample variability in SSC ranged from 4.6 to 22 percent). In addition, the total daily loads estimated within the chute using turbidity surrogates indicated that when main-channel EWI samples were collected, 2 of the 7 days had slight deposition in the chute, 3 of the 7 days had slight erosion within the chute, and 2 of the 7 days did not have continuous data available; therefore, loads could not be estimated. The possibility exists that the small sample size; the variability within the data (concentrations for each EWI sample are in appendix 1); and, to some extent, the construction within the chute may have some effect on these results. When data for the Missouri River transects at both study chutes (Upper Hamburg and Kansas) were combined and upstream and downstream transects compared, no significant differences were detected (table 6).

An additional comparison that analyzed the effect a chute might have on the main channel used the concentration of sediment at the downstream transect of the chute and the concentration of sediment at the Missouri River upstream transect. If the chute concentrations are significantly higher, then theoretically, the chute is adding sediment to the main channel even if the contribution was not detected when comparing the Missouri River upstream transect to the Missouri River downstream transect. In contrast, if the chute concentrations are significantly lower, then the outflow of the chute is diluting the sediment within the main channel; however, the only comparison that was significant was that the SSiltC was greater at the Missouri River upstream transect than at the chute downstream transect of Upper Hamburg chute (table 6). Four of the seven pairs of samples collected at Upper Hamburg were collected after the chute inlet had been closed; this likely had the effect of decreasing the SSC within the chute (table 3 ). If inlet closure were causing the significant difference in SSiltC, the corresponding difference also would be expected to be significant for comparisons using total SSC and SSandC. These results are inconsistent, likely because of the small sample size and the inherent variability of suspended-sediment sampling techniques.

Comparisons of concentrations and loads between the Missouri River upstream and downstream transects, as well as comparison of concentrations between the Missouri River upstream and the chute downstream, were also completed with the addition of four to five samples collected in 2008 at the Upper Hamburg study site (table 6). The results indicated that the differences between the Missouri River upstream and the Missouri River downstream in SSC and total SSL were significant only when both chutes were combined; therefore, data from Kansas study site were included. In addition, the inclusion of Kansas chute data in the comparison of Missouri River upstream and chute downstream concentrations also resulted in significant differences with higher SSC and SSandC in the Missouri River upstream. The comparison results likely were affected by the number of samples collected from Upper Hamburg study site when the inlet to the chute was closed and by the variability in other samples. For example, in the October sample, the SSC was 296 milligrams per liter for the sample collected at the Missouri River upstream from Kansas chute, whereas the SSC was only 64 milligrams per liter for the sample collected at the chute (appendix 1). Also for the October Missouri River sample, the percentage finer than 0.062 millimeter was low because the sand concentration was high. These data were not censored because similar results were observed at the Missouri River downstream transect during the October sample as well (total SSC was 317 milligrams per liter and a low SF split). The significant differences in SSC and the $S S a n d C$ indicate that the Missouri River had a higher sediment concentration; therefore, the chute outflow was diluting the sediment within the main channel on the 8 or 9 days that the sites were sampled.

Comparison of EWI samples between different transects within a study site were limited by few samples and large variability. When comparing the Missouri River upstream transect to the upstream transect of the chute, however, similar results were determined in 2012 (table 6) as were determined in 2008 at Upper Hamburg and Glovers chutes (Woodward and Rus, 2011); the chute inlet affected the amount of sediment entering the chute from the main channel. In addition, the Kansas chute is potentially affecting the sediment concentration within the Missouri River main channel, but small sample size and construction activities within the chute limited the ability in this 
study to fully understand either the effect of the chute in 2012 or the effect of the chute on the main channel during a "typical year" without construction. Some differences in SSC were detected between the Missouri River upstream transect and the downstream transect of the chute; however, general conclusions about the typical effect of the chutes on the Missouri River main-channel sediment transport were difficult to determine because of the effect of the closure of the inlet structure at Upper Hamburg chute and the presence of one nontypical sample from the Missouri River transect at Kansas chute.

\section{Summary}

Understanding chute evolution through sediment movement is important for the design of chutes, monitoring and maintenance of existing chutes, and characterizing the habitat that the chutes provide. The U.S. Geological Survey, in cooperation with the U.S. Army Corps of Engineers, monitored suspended sediment within constructed Missouri River chutes during March through October 2012. Chutes were constructed at selected river bends by the U.S. Army Corps of Engineers to help mitigate aquatic habitat lost through the creation and maintenance of the navigation channel on the Missouri River. The restoration and development of chutes is one method for creating shallow-water habitat within the Missouri River to meet requirements established by the amended 2000 Biological Opinion. Specific objectives of this study were to (1) provide sediment and water-quality data on chutes to better understand their geomorphic processes; (2) to quantify and compare suspended-sediment concentrations (SSC), loads, and size distributions of the chutes to those of the Missouri River main channel; (3) to determine variation among water-quality properties within chutes; and (4) to develop a model of the relation between turbidity and SSC that evaluates the use of turbidity as a surrogate for SSC. This report describes the methods used to monitor suspended sediment at two Missouri River chutes and presents the results of the data analysis to help understand the suspended-sediment characteristics of each chute and the effect the chutes have on the Missouri River.

Upper Hamburg chute, near Nebraska City, Nebraska, and Kansas chute, near Peru, Nebraska, were selected for monitoring. At each study site, monthly suspended-sediment samples were collected from April through October in Missouri River main-channel transects upstream from the chute inlet and downstream from the chute outlet. Monthly suspended-sediment samples were also collected from April through October 2012 at the outlet (downstream transect) of both chutes and at the inlet (upstream transect) of Kansas chute. These discrete samples were collected from the channel cross section at equal-width increments (EWI) using depthintegrating methods. In addition, grab samples were collected for all chute sampling locations by using automatic samplers throughout the study period. Continuous water-quality monitors recorded turbidity and water temperature at 15-minute intervals at the three chute sampling locations, and two acoustic Doppler velocimeters, one within each chute, measured water depth and current velocities continuously during March through October 2012. The depth and velocity data were used to estimate continuous streamflow within each chute. The sampling design was developed to understand the suspendedsediment differences within each chute and between the chute and the Missouri River main channel during discrete sampling. The sampling design also allowed for site-specific surrogate relations between SSC and turbidity to be developed, which could be used to compute real-time estimates of SSC and sediment loads within the chutes. Real-time estimates of SSC and sediment loads enable a better understanding of sediment transport within the chutes during times when physical samples are not collected, including periods of high flow.

High flows during the summer of 2011 resulted in substantial alterations to both studied chutes; therefore, the U.S. Army Corps of Engineers repaired and modified both chutes during 2012. These unforeseen repairs and modifications within the chutes added an unknown degree of uncertainty to the analysis because concentrations were altered by construction equipment and flow alteration.

A linear regression was used to estimate EWI-equivalent SSC from autosampler SSC before using the model-calibration dataset to determine the best-fit model for prediction of SSC from the turbidity and, in some cases, streamflow. Correlation between suspended-sand concentration (SSandC) in EWI samples and concurrent samples collected by an autosampler was low; therefore, $S S a n d C$ was excluded from development of surrogate relations because a large part of the calibration dataset was from automatic samples. Instead, SSandC was estimated as SSC minus suspended-silt-clay concentration (SSiltC). At all sites, the best-fit models included the base10 logarithm of concentration and turbidity, and at Kansas chute upstream, the base-10 logarithm of streamflow was also included in the best-fit models. Estimated daily suspendedsediment loads from the turbidity-based surrogate models were not significantly different between upstream and downstream transects within the Kansas chute, and most individual daily loads within the chute were not significantly different between the upstream and downstream transects when evaluated using overlap in daily 95 -percent confidence intervals. The comparison of daily load values for upstream and downstream transects, estimated from turbidity-based surrogate models for the Kansas chute, documents the dynamic nature of sediment transport within the chute with a temporal resolution that is not practical with discrete suspended-sediment sampling alone.

Comparisons of concentrations and loads from EWI samples collected from different transects (Missouri River upstream as compared to chute upstream, chute upstream as compared to chute downstream, Missouri River upstream as compared to Missouri River downstream, and Missouri River upstream as compared to chute downstream) within a study site resulted in few significant differences because comparisons were limited by small sample sizes and large within-transect variability. When comparing the Missouri River upstream 
transect to the chute upstream transect, similar results were determined in 2012 as were determined in 2008 - the chute inlet affected the amount of sediment entering the chute from the main channel. In addition, the Kansas chute is potentially affecting the sediment concentration within the Missouri River main channel, but small sample size and construction activities within the chute limit the ability to fully understand either the effect of the chute in 2012 or the effect of the chute on the main channel during a "typical year" without construction. Finally, some differences in SSC were detected between the Missouri River upstream transects and the chute downstream transects; however, the effect of the chutes on the Missouri River main-channel sediment transport was difficult to isolate because of construction activities and sampling variability.

\section{References Cited}

Capel, P.D., and Larson, S.J., 1996, Evaluation of selected information on splitting devices for water samples: U.S. Geological Survey Water-Resources Investigations Report 95-4141, 103 p. [Also available at http://pubs.usgs.gov/ wri/1995/4141/report.pdf.]

Christensen, V.C., 2001, Characterization of surface-water quality based on real-time monitoring and regression analysis, Quivira National Wildlife Refuge, south central Kansas, December 1998 through June 2001: U.S. Geological Survey Water-Resources Investigations Report 01-4248, 28 p. [Also available at http://ks.water.usgs.gov/pubs/reports/ wrir.01-4248.html.]

Davis, B.E., 2005, A guide to the proper selection and use of federally approved sediment and water-quality samplers: U.S. Geological Survey Open-File Report 2005-1087, 20 p. [Also available at http://pubs.usgs.gov/of/2005/1087/.]

Edwards, T.K., and Glysson, G.D., 1999, Field methods for measurement of fluvial sediment: U.S. Geological Survey Techniques of Water-Resources Investigations, book 3, chap. C2, 89 p. [Also available at http://pubs.usgs.gov/twri/ twri3-c2/.]

Funk, J.L., and Robinson, J.W., 1974, Changes in the channel of the Lower Missouri River and effects on fish and wildlife: Missouri Department of Conservation Aquatic Series No. 11, Jefferson City, Missouri, 52 p.

Gosch, N.J.C., Miller, M.L., Gemeinhardt, T.R., Sampson, S.J., Bonneau, J.L., 2015, Age-0 sturgeon accessibility to constructed and modified chutes in the Lower Missouri River: North American Journal of Fisheries Management, v. 35 , no. 1 , p. 75-85.

Guy, H.P., 1969, Laboratory theory and methods for sediment analysis: U.S. Geological Survey Techniques of WaterResources Investigations, book 5, chap. Cl, 58 p.
Helsel, D.R., and Hirsch, R.M., 2002, Statistical methods in Water Resources: U.S. Geological Survey Techniques of Water-Resources Investigations, book 4, chap. A3, 522 p., accessed December 2, 2015, at http://pubs.usgs.gov/twri/ twri4a3/.

Julien, P.Y., 2010, Erosion and sedimentation (2d ed.): New York, Cambridge University Press, 371 p.

Krahulik, J.R., Densmore, B.K., Anderson, K.J., and Kavan, C.L., 2015, Hydrographic surveys at seven chutes and three backwaters on the Missouri River in Nebraska, Iowa, and Missouri, 2011-13: U.S. Geological Survey Data Series 909, 28 p. [Also available at http://dx.doi.org/10.3133/ ds909.]

Lee, M.T., Asquith, W.H., and Oden, T.D., 2012, Regression model development and computational procedures to support estimation of real-time concentrations and loads of selected constituents in two tributaries to Lake Houston near Houston, Texas, 2005-9: U.S. Geological Survey Scientific Investigations Report 2012-5006, 40 p. [Also available at http://pubs.usgs.gov/sir/2012/5006/.]

Levesque, V.A., and Oberg, K.A., 2012, Computing discharge using the index velocity method: U.S. Geological Survey Techniques and Methods, book 3, chap. A23, 148 p. [Also available at http://pubs.usgs.gov/tm/3a23/.]

Mueller, D.S., and Wagner, C.R., 2009, Measuring discharge with acoustic Doppler current profilers from a moving boat: U.S. Geological Survey Techniques and Methods, book 3, chap. A22, 95 p. [Also available at http://pubs.usgs.gov/ tm/3a22/pdf/tm3a22_lowres.pdf.]

Newman, M.C., 1993, Regression analysis of log-transformed data-Statistical bias and its correction: Environmental Toxicology and Chemistry, v. 12, p. 1129-1133.

Oberg, K.A., Morlock, S.E., and Caldwell, W.S., 2005, Quality-assurance plan for discharge measurements using acoustic Doppler current profilers: U.S. Geological Survey Scientific Investigations Report 2005-5183, 35 p. [Also available at http://pubs.usgs.gov/sir/2005/5183/.]

Ott, R.L., and Longnecker, Michael, 2001, An introduction to statistical methods and data analysis (5th ed.): Pacific Grove, Calif., Duxbury, 1152 p.

Rasmussen, P.P., Gray, J.R., Glysson, G.D., and Ziegler, A.C., 2009, Guidelines and procedures for computing time-series suspended-sediment concentrations and loads from instream turbidity-sensor and streamflow data: U.S. Geological Survey Techniques and Methods, book 3, chap. C4, 53 p. [Also available at http://pubs.usgs.gov/tm/tm3c4/.] 
Rasmussen, T.J., Ziegler, A.C., and Rasmussen, P.P., 2005, Estimation of constituent concentrations, densities, loads, and yields in lower Kansas River, northeast Kansas, using regression models and continuous water-quality monitoring, January 2000 through December 2003: U.S. Geological Survey Scientific Investigations Report 2005-5165, 117 p. [Also available at http://pubs.usgs.gov/sir/2005/5165/.]

Reinig, T., and Roth, M., 2010, Missouri River Recovery Program - Collaborative Partnerships Lead to Success: U.S. Army Corps of Engineers, 14 p., accessed January 8, 2016, at http://ussdams.com/proceedings/2010Proc/1005-1018. pdf.

Ruhl, C.A., and Simpson, M.R., 2005, Computation of discharge using the index-velocity method in tidally affected areas: U.S. Geological Survey Scientific Investigations Report 2005-5004, 31 p. [Also available at http://pubs.usgs. gov/sir/2005/5004/.]

Schaepe, N.J., Soenksen, P.J., and Rus, D.L., 2014, Relations of water-quality constituent concentrations to surrogate measurements in the lower Platte River corridor, Nebraska, 2007 through 2011: U.S. Geological Survey Open-File Report 2014-1149, 16 p. [Also available at http://pubs.usgs. gov/of/2014/1149.]

SonTek Corporation, 2000, SonTek ADVM-series instruments technical documentation: San Diego, Calif., SonTek Corporation, $77 \mathrm{p}$.

Sterner, V., Bowman, R., Eder, B.L., Negus, S., Mestl, G.E., Whiteman, K., Garner, D., Travnichek, V., Schloesser, J., McMullen, J., and Hill, T., 2009, FINAL REPORT-Missouri River fish and wildlife mitigation program-Fish community monitoring and habitat assessment of offchannel mitigation sites: Nebraska Game and Parks Commission-Staff Research Publications, Paper 57, 1,422 p. [Also available at http://moriverrecovery.usace.army.mil/ mrrp/f?p=136:6:0::NO.]

U.S. Army Corps of Engineers, 2014, Missouri River Recovery Program-Shallow Water Habitat (SWH): U.S. Army Corps of Engineers, Biological Opinion Efforts Web pages, accessed September 26, 2014, at http://moriverrecovery. usace. $\operatorname{army} . \mathrm{mil} / \mathrm{mrrp} / \mathrm{f} ? \mathrm{p}=136: 131: 0:: \mathrm{NO}$.
U.S. Army Corps of Engineers and U.S. Fish and Wildlife Service, 2013, 2012 Annual report for the Biological Opinion on the operation of the Missouri River main stem system, operation and maintenance of the Missouri River Bank Stabilization and Navigation Project, and the operation of the Kansas River reservoir system: Omaha, Nebr., U.S. Army Corps of Engineers, Omaha and Kansas City Districts, $179 \mathrm{p}$.

U.S. Fish and Wildlife Service, 2000, Biological opinion on the operation of the Missouri River main stem reservoir system, operation and maintenance of the Missouri River bank stabilization and navigation project, and operation of the Kansas River reservoir system: Minneapolis, Minn., U.S. Fish and Wildlife Service, 286 p.

U.S. Geological Survey, 2012, USGS Surface-water data for the Nation: U.S. Geological Survey Web pages, accessed November 1, 2009, at http://waterdata.usgs.gov/nwis/sw.

U.S. Geological Survey, variously dated, National field manual for the collection of water-quality data: U.S. Geological Survey Techniques of Water-Resources Investigations, book 9, chaps. A1-A10, variously paged. [Also available at http:// water.usgs.gov/owq/FieldManual/. Chapter updates and revisions are ongoing and are summarized at http://water. usgs.gov/owq/FieldManual/mastererrata.html.]

Wagner, R.J.; Boulger, R.W., Jr.; Oblinger, C.J.; and Smith, B.A., 2006, Guidelines and standard procedures for continuous water-quality monitors-Station operation, record computation, and data reporting: U.S. Geological Survey Techniques and Methods, book 1, chap. D3, 51 p. [Also available at http://pubs.usgs.gov/tm/2006/tm1D3/].

Woodward, B.K., and Rus, D.L., 2011, Characteristics of suspended and streambed sediment within constructed chutes and the main channel at Upper Hamburg and Glovers Point Bends, Missouri River, Nebraska, 2008: U.S. Geological Survey Open-File Report 2011-1049, 29 p. [Also available at http://pubs.usgs.gov/of/2011/1049/]. 
Tables 3 and 5 
Table 3. Total daily loads calculated from instantaneous estimates of suspended-sediment concentration from turbidity surrogate at Upper Hamburg chute and Kansas chute, 2012.

[KANS-CH-US, Kansas chute upstream; KANS-CH-DS, Kansas chute downstream; UHAM-CH-DS, Upper Hamburg chute downstream; nd, no data. Green highlighted cells indicate construction]

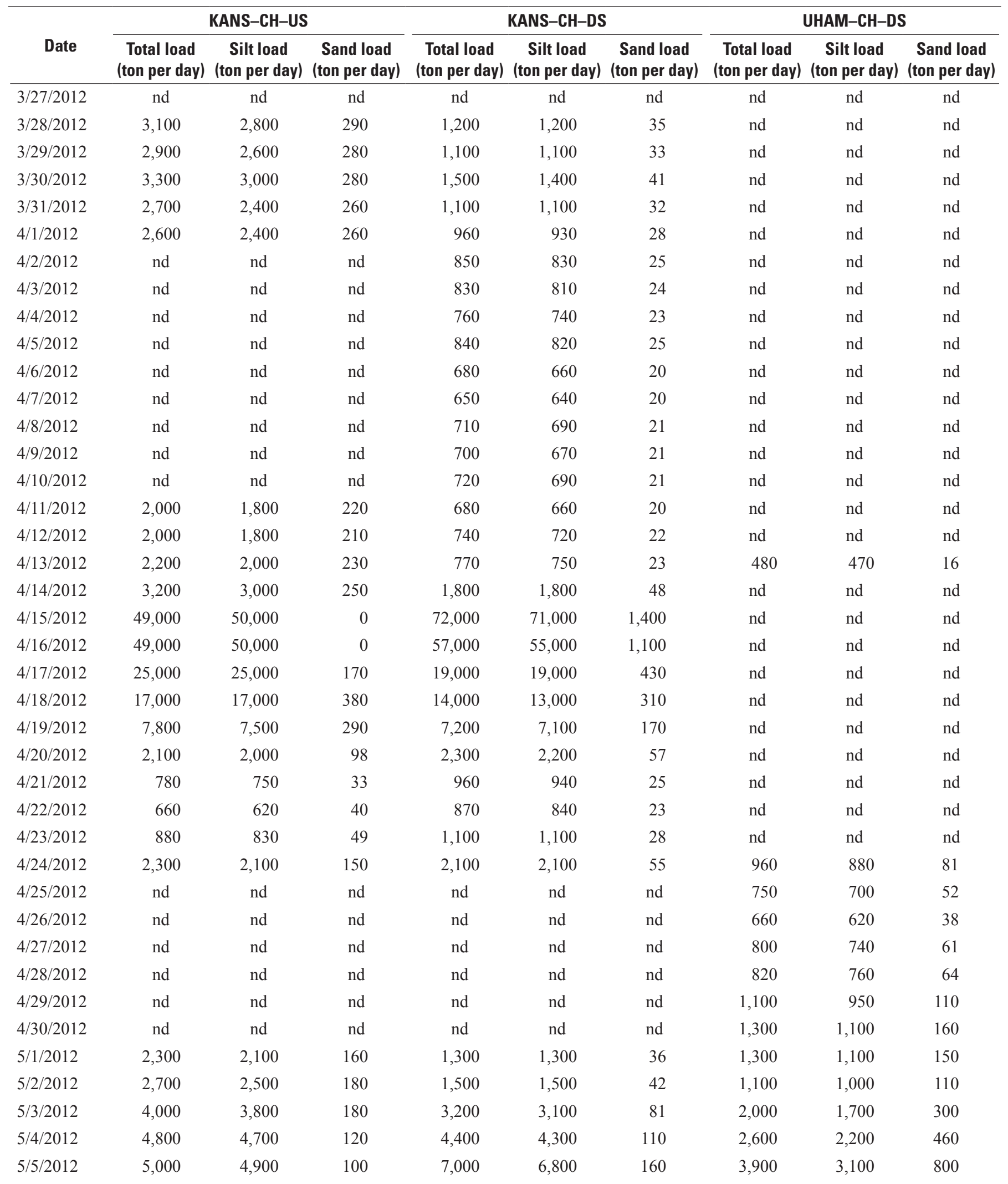


Table 3. Total daily loads calculated from instantaneous estimates of suspended-sediment concentration from turbidity surrogate at Upper Hamburg chute and Kansas chute, 2012.-Continued

[KANS-CH-US, Kansas chute upstream; KANS-CH-DS, Kansas chute downstream; UHAM-CH-DS, Upper Hamburg chute downstream; nd, no data. Green highlighted cells indicate construction]

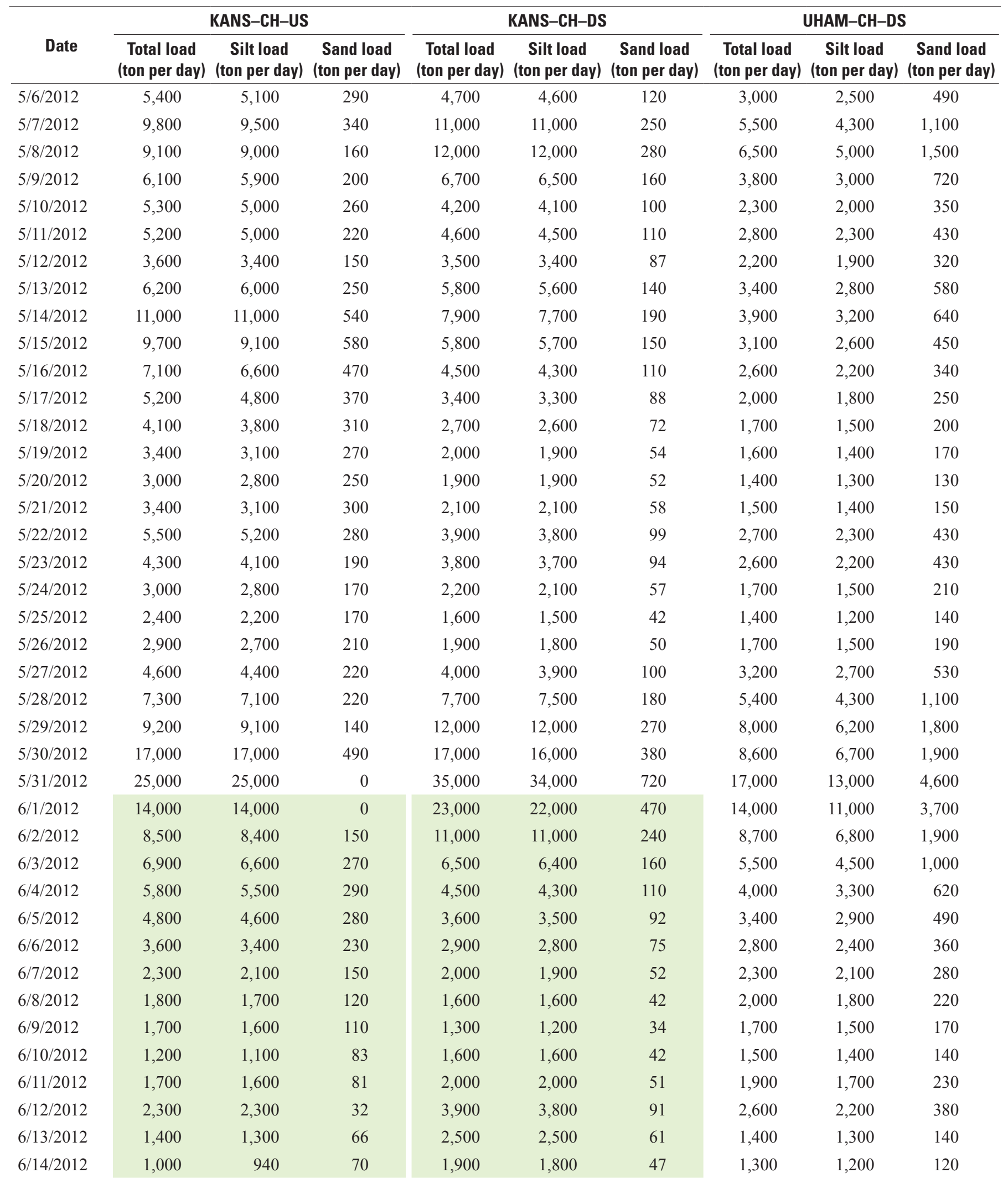


Table 3. Total daily loads calculated from instantaneous estimates of suspended-sediment concentration from turbidity surrogate at Upper Hamburg chute and Kansas chute, 2012.-Continued

[KANS-CH-US, Kansas chute upstream; KANS-CH-DS, Kansas chute downstream; UHAM-CH-DS, Upper Hamburg chute downstream; nd, no data. Green highlighted cells indicate construction]

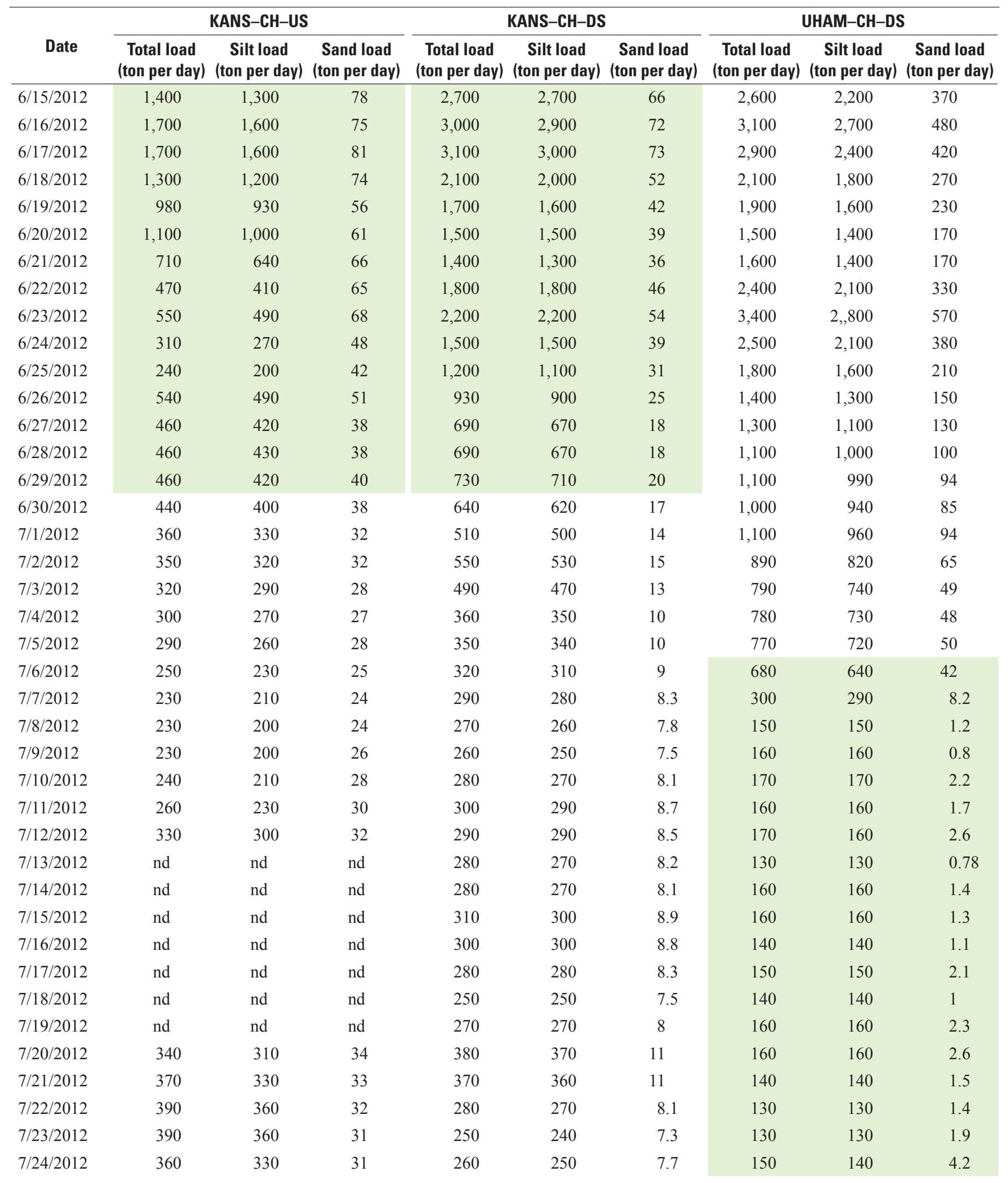


Table 3. Total daily loads calculated from instantaneous estimates of suspended-sediment concentration from turbidity surrogate at Upper Hamburg chute and Kansas chute, 2012. - Continued

[KANS-CH-US, Kansas chute upstream; KANS-CH-DS, Kansas chute downstream; UHAM-CH-DS, Upper Hamburg chute downstream; nd, no data. Green highlighted cells indicate construction]

\begin{tabular}{|c|c|c|c|c|c|c|c|c|c|}
\hline \multirow[b]{2}{*}{ Date } & \multicolumn{3}{|c|}{ KANS-CH-US } & \multicolumn{3}{|c|}{ KANS-CH-DS } & \multicolumn{3}{|c|}{ UHAM-CH-DS } \\
\hline & $\begin{array}{c}\text { Total load } \\
\text { (ton per day) }\end{array}$ & $\begin{array}{c}\text { Silt load } \\
\text { (ton per day) }\end{array}$ & $\begin{array}{c}\text { Sand load } \\
\text { (ton per day) }\end{array}$ & $\begin{array}{c}\text { Total load } \\
\text { (ton per day) }\end{array}$ & $\begin{array}{c}\text { Silt load } \\
\text { (ton per day) }\end{array}$ & $\begin{array}{c}\text { Sand load } \\
\text { (ton per day) }\end{array}$ & $\begin{array}{c}\text { Total load } \\
\text { (ton per day) }\end{array}$ & $\begin{array}{c}\text { Silt load } \\
\text { (ton per day) }\end{array}$ & $\begin{array}{c}\text { Sand load } \\
\text { (ton per day) }\end{array}$ \\
\hline $7 / 26 / 2012$ & 280 & 250 & 28 & 220 & 210 & 6.4 & 150 & 150 & 2.9 \\
\hline $7 / 27 / 2012$ & 270 & 240 & 27 & 180 & 180 & 5.5 & 120 & 120 & 0.79 \\
\hline $7 / 30 / 2012$ & nd & nd & nd & nd & nd & nd & 120 & 120 & 1.1 \\
\hline $7 / 31 / 2012$ & nd & nd & nd & nd & nd & nd & 130 & 130 & 1.1 \\
\hline $8 / 1 / 2012$ & nd & nd & nd & nd & nd & nd & 130 & 130 & 1.6 \\
\hline $8 / 2 / 2012$ & 140 & 130 & 14 & 150 & 150 & 4.5 & 130 & 130 & 1.6 \\
\hline 8/6/2012 & 370 & 330 & 36 & 270 & 270 & 8.1 & 150 & 140 & 3 \\
\hline 8/7/2012 & 350 & 320 & 34 & 270 & 260 & 8 & 170 & 170 & 4.8 \\
\hline $8 / 8 / 2012$ & 380 & 350 & 36 & 300 & 290 & 8.8 & 170 & 170 & 4.9 \\
\hline $8 / 9 / 2012$ & 430 & 390 & 39 & 340 & 330 & 9.9 & 180 & 180 & 4.6 \\
\hline $8 / 10 / 2012$ & 400 & 360 & 37 & 320 & 310 & 9.3 & 170 & 160 & 4 \\
\hline $8 / 11 / 2012$ & 400 & 360 & 37 & 340 & 330 & 9.9 & 170 & 170 & 4.5 \\
\hline $8 / 12 / 2012$ & 430 & 390 & 38 & 400 & 390 & 11 & 190 & 180 & 5.7 \\
\hline $8 / 13 / 2012$ & nd & nd & nd & 390 & 380 & 11 & 180 & 180 & 6 \\
\hline $8 / 14 / 2012$ & nd & nd & nd & 350 & 340 & 10 & 160 & 160 & 3.9 \\
\hline $8 / 20 / 2012$ & 420 & 390 & 34 & 450 & 430 & 12 & 200 & 190 & 7.2 \\
\hline $8 / 21 / 2012$ & 380 & 350 & 35 & 370 & 360 & 11 & 170 & 170 & 4.5 \\
\hline $8 / 22 / 2012$ & 380 & 350 & 35 & 360 & 350 & 10 & 170 & 170 & 4.6 \\
\hline $8 / 23 / 2012$ & 430 & 390 & 35 & 470 & 450 & 13 & 170 & 170 & 5.3 \\
\hline $8 / 24 / 2012$ & nd & nd & nd & 460 & 450 & 13 & 200 & 190 & 7.4 \\
\hline $8 / 25 / 2012$ & nd & nd & nd & 610 & 590 & 17 & 210 & 200 & 7.1 \\
\hline $8 / 26 / 2012$ & nd & nd & nd & nd & nd & nd & 200 & 190 & 5.3 \\
\hline $8 / 27 / 2012$ & nd & nd & nd & nd & nd & nd & 200 & 190 & 5.9 \\
\hline $8 / 28 / 2012$ & 400 & 360 & 38 & nd & nd & nd & 210 & 200 & 6.7 \\
\hline $8 / 29 / 2012$ & 390 & 350 & 36 & 370 & 360 & 11 & 210 & 200 & 7.7 \\
\hline $8 / 30 / 2012$ & 380 & 340 & 35 & 380 & 370 & 11 & 210 & 200 & 9.6 \\
\hline $8 / 31 / 2012$ & 320 & 290 & 31 & 410 & 400 & 11 & 190 & 180 & 8.9 \\
\hline $9 / 1 / 2012$ & 300 & 270 & 28 & 380 & 370 & 11 & 170 & 170 & 6.7 \\
\hline $9 / 2 / 2012$ & 390 & 360 & 35 & 650 & 640 & 18 & 210 & 200 & 11 \\
\hline
\end{tabular}


Table 3. Total daily loads calculated from instantaneous estimates of suspended-sediment concentration from turbidity surrogate at Upper Hamburg chute and Kansas chute, 2012.-Continued

[KANS-CH-US, Kansas chute upstream; KANS-CH-DS, Kansas chute downstream; UHAM-CH-DS, Upper Hamburg chute downstream; nd, no data. Green highlighted cells indicate construction]

\begin{tabular}{|c|c|c|c|c|c|c|c|c|c|}
\hline \multirow[b]{2}{*}{ Date } & \multicolumn{3}{|c|}{ KANS-CH-US } & \multicolumn{3}{|c|}{ KANS-CH-DS } & \multicolumn{3}{|c|}{ UHAM-CH-DS } \\
\hline & $\begin{array}{c}\text { Total load } \\
\text { (ton per day) }\end{array}$ & $\begin{array}{c}\text { Silt load } \\
\text { (ton per day) }\end{array}$ & $\begin{array}{c}\text { Sand load } \\
\text { (ton per day) }\end{array}$ & $\begin{array}{c}\text { Total load } \\
\text { (ton per day) }\end{array}$ & $\begin{array}{c}\text { Silt load } \\
\text { (ton per day) }\end{array}$ & $\begin{array}{c}\text { Sand load } \\
\text { (ton per day) }\end{array}$ & $\begin{array}{c}\text { Total load } \\
\text { (ton per day) }\end{array}$ & $\begin{array}{c}\text { Silt load } \\
\text { (ton per day) }\end{array}$ & $\begin{array}{c}\text { Sand load } \\
\text { (ton per day) }\end{array}$ \\
\hline $9 / 4 / 2012$ & 370 & 330 & 34 & 440 & 420 & 12 & 230 & 210 & 15 \\
\hline $9 / 5 / 2012$ & 380 & 340 & 34 & 480 & 470 & 13 & 210 & 200 & 10 \\
\hline $9 / 8 / 2012$ & 380 & 350 & 35 & 480 & 470 & 13 & 180 & 170 & 6.8 \\
\hline 9/9/2012 & 390 & 350 & 36 & 480 & 470 & 13 & 170 & 160 & 5.2 \\
\hline $9 / 10 / 2012$ & 400 & 370 & 35 & 530 & 520 & 15 & 180 & 170 & 7.8 \\
\hline $9 / 11 / 2012$ & 380 & 340 & 35 & 470 & 460 & 13 & 180 & 170 & 7.6 \\
\hline $9 / 15 / 2012$ & 460 & 420 & 40 & 630 & 620 & 17 & 210 & 200 & 8.6 \\
\hline $9 / 16 / 2012$ & 400 & 360 & 36 & 700 & 680 & 19 & 200 & 200 & 8.6 \\
\hline $9 / 17 / 2012$ & 380 & 350 & 35 & 850 & 820 & 22 & 220 & 210 & 11 \\
\hline $9 / 18 / 2012$ & 340 & 310 & 34 & 760 & 740 & 20 & 180 & 180 & 6.8 \\
\hline 9/19/2012 & 330 & 300 & 34 & 730 & 710 & 19 & 170 & 170 & 5.6 \\
\hline $9 / 20 / 2012$ & 340 & 310 & 34 & 620 & 610 & 17 & 170 & 170 & 4.8 \\
\hline $9 / 21 / 2012$ & 410 & 370 & 35 & 730 & 710 & 19 & 220 & 210 & 12 \\
\hline $9 / 22 / 2012$ & 410 & 380 & 34 & 630 & 610 & 17 & 220 & 210 & 12 \\
\hline $9 / 23 / 2012$ & 380 & 340 & 34 & 440 & 430 & 12 & 180 & 170 & 6.4 \\
\hline $9 / 29 / 2012$ & 370 & 330 & 34 & 420 & 400 & 12 & nd & nd & nd \\
\hline 9/30/2012 & 380 & 350 & 35 & 420 & 410 & 12 & nd & nd & nd \\
\hline $10 / 1 / 2012$ & 370 & 330 & 34 & 400 & 390 & 11 & nd & nd & nd \\
\hline $10 / 2 / 2012$ & 340 & 310 & 34 & 360 & 350 & 10 & nd & nd & nd \\
\hline $10 / 3 / 2012$ & 350 & 320 & 34 & 410 & 400 & 12 & nd & nd & nd \\
\hline $10 / 4 / 2012$ & 370 & 340 & 34 & 460 & 440 & 13 & nd & nd & nd \\
\hline $10 / 5 / 2012$ & 330 & 300 & 34 & 350 & 340 & 10 & 130 & 130 & 1.9 \\
\hline $10 / 6 / 2012$ & 340 & 300 & 35 & 360 & 350 & 10 & 140 & 140 & 2.7 \\
\hline $10 / 7 / 2012$ & 330 & 300 & 35 & 360 & 350 & 10 & 140 & 130 & 3.7 \\
\hline $10 / 8 / 2012$ & 340 & 310 & 35 & 400 & 390 & 11 & 150 & 140 & 5.4 \\
\hline $10 / 9 / 2012$ & 360 & 320 & 34 & 430 & 420 & 12 & 180 & 170 & 7.3 \\
\hline $10 / 10 / 2012$ & 350 & 320 & 34 & 370 & 360 & 10 & 170 & 160 & 6.9 \\
\hline $10 / 11 / 2012$ & 350 & 310 & 34 & 360 & 350 & 10 & 200 & 190 & 9.3 \\
\hline $10 / 12 / 2012$ & 340 & 310 & 34 & 370 & 360 & 11 & 190 & 180 & 9.2 \\
\hline
\end{tabular}


Table 3. Total daily loads calculated from instantaneous estimates of suspended-sediment concentration from turbidity surrogate at Upper Hamburg chute and Kansas chute, 2012.-Continued

[KANS-CH-US, Kansas chute upstream; KANS-CH-DS, Kansas chute downstream; UHAM-CH-DS, Upper Hamburg chute downstream; nd, no data. Green highlighted cells indicate construction]

\begin{tabular}{|c|c|c|c|c|c|c|c|c|c|}
\hline \multirow[b]{2}{*}{ Date } & \multicolumn{3}{|c|}{ KANS-CH-US } & \multicolumn{3}{|c|}{ KANS-CH-DS } & \multicolumn{3}{|c|}{ UHAM-CH-DS } \\
\hline & $\begin{array}{c}\text { Total load } \\
\text { (ton per day) }\end{array}$ & $\begin{array}{c}\text { Silt load } \\
\text { (ton per day) }\end{array}$ & $\begin{array}{c}\text { Sand load } \\
\text { (ton per day) }\end{array}$ & $\begin{array}{c}\text { Total load } \\
\text { (ton per day) }\end{array}$ & $\begin{array}{c}\text { Silt load } \\
\text { (ton per day) }\end{array}$ & $\begin{array}{c}\text { Sand load } \\
\text { (ton per day) }\end{array}$ & $\begin{array}{c}\text { Total load } \\
\text { (ton per day) }\end{array}$ & $\begin{array}{c}\text { Silt load } \\
\text { (ton per day) }\end{array}$ & $\begin{array}{c}\text { Sand load } \\
\text { (ton per day) }\end{array}$ \\
\hline $10 / 14 / 2012$ & 420 & 390 & 37 & 560 & 550 & 15 & 290 & 270 & 21 \\
\hline $10 / 15 / 2012$ & 410 & 370 & 38 & 470 & 460 & 13 & 270 & 250 & 20 \\
\hline $10 / 18 / 2012$ & 340 & 310 & 35 & 530 & 520 & 15 & nd & nd & nd \\
\hline $10 / 19 / 2012$ & 330 & 290 & 34 & 340 & 330 & 9.8 & nd & nd & nd \\
\hline $10 / 20 / 2012$ & 300 & 270 & 33 & 290 & 290 & 8.6 & nd & nd & nd \\
\hline $10 / 21 / 2012$ & 320 & 290 & 34 & 370 & 360 & 11 & nd & nd & nd \\
\hline $10 / 25 / 2012$ & 490 & 440 & 52 & 650 & 630 & 18 & nd & nd & nd \\
\hline $10 / 26 / 2012$ & 480 & 430 & 53 & 600 & 580 & 17 & nd & nd & nd \\
\hline $10 / 27 / 2012$ & 310 & 280 & 35 & 390 & 380 & 11 & nd & nd & nd \\
\hline $10 / 28 / 2012$ & 300 & 260 & 34 & 330 & 320 & 9.7 & nd & nd & nd \\
\hline $10 / 29 / 2012$ & 290 & 260 & 34 & 330 & 320 & 9.5 & nd & nd & nd \\
\hline $10 / 30 / 2012$ & nd & nd & nd & nd & nd & nd & nd & nd & nd \\
\hline $10 / 31 / 2012$ & nd & nd & nd & nd & nd & nd & nd & nd & nd \\
\hline
\end{tabular}




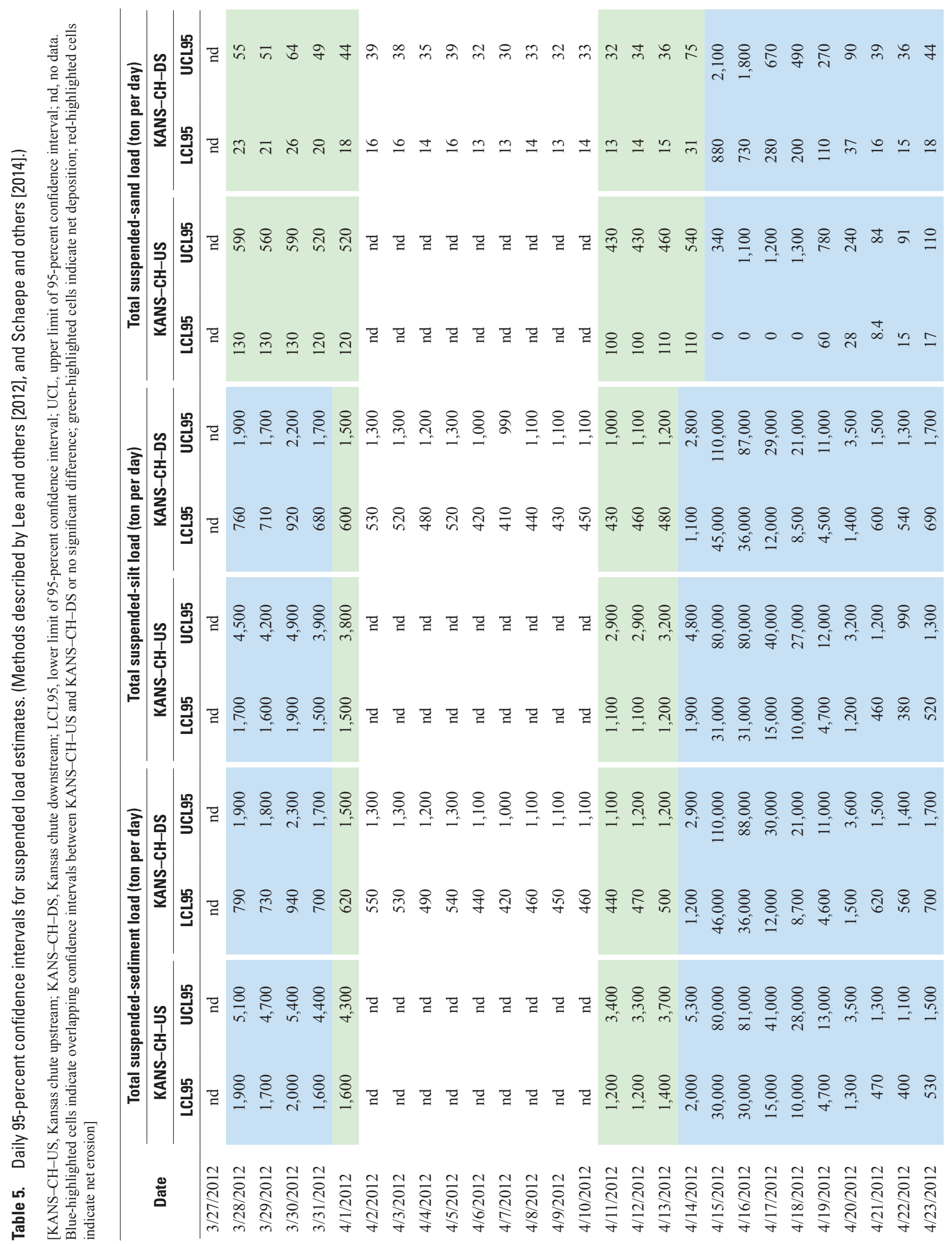




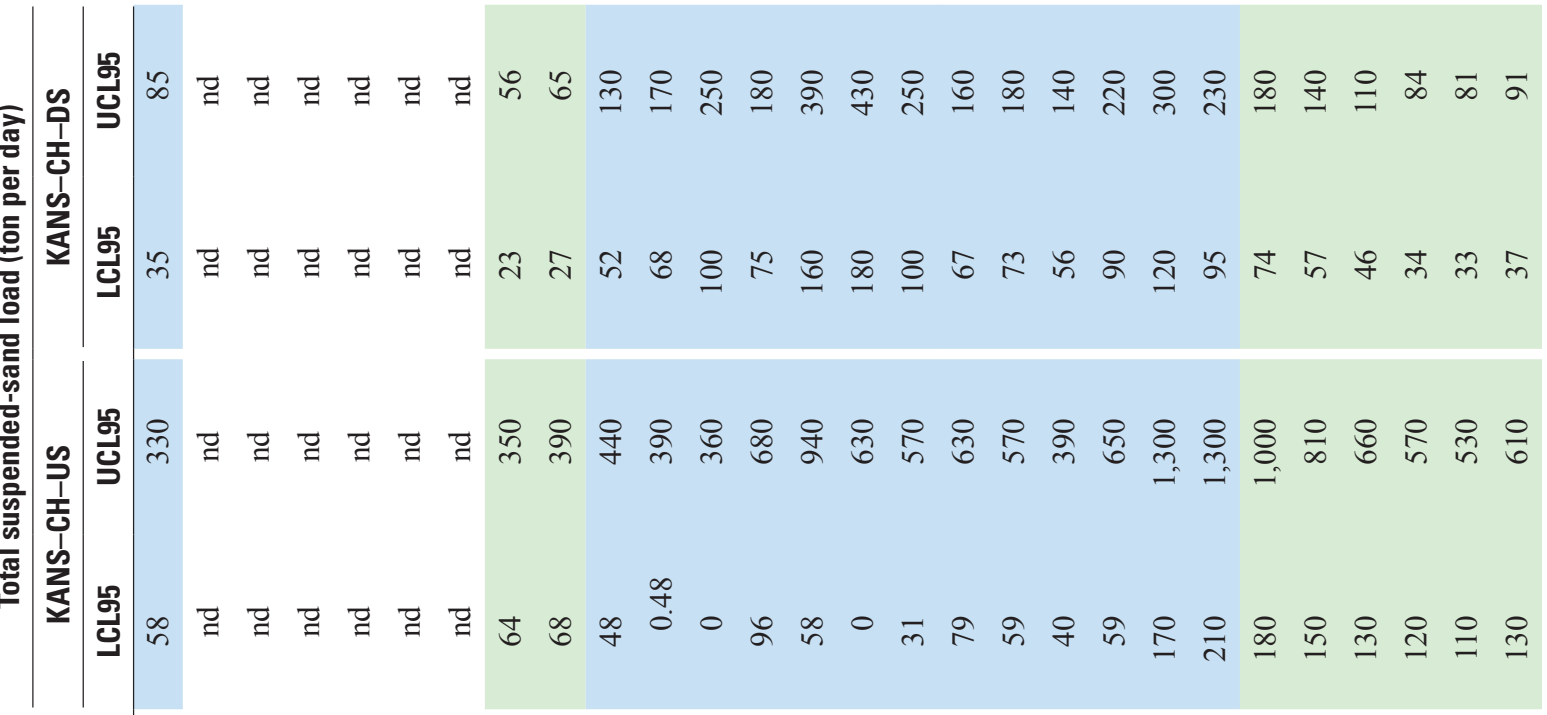

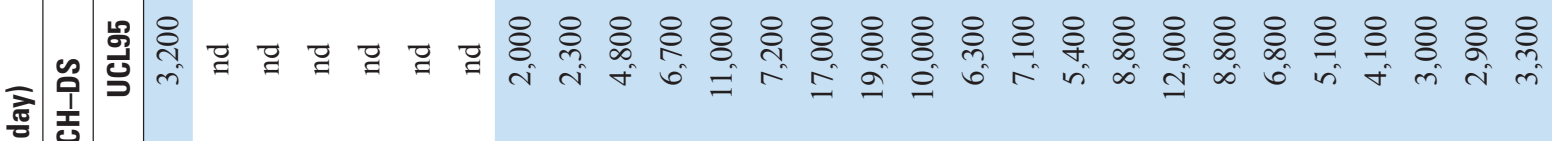

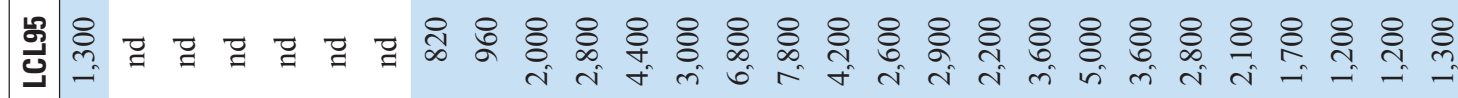

至

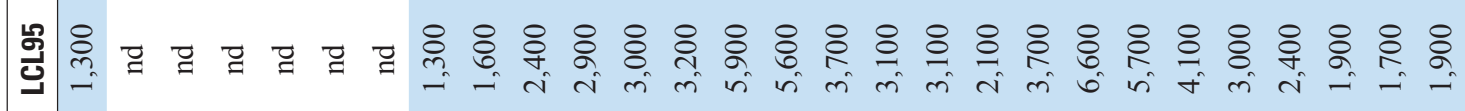




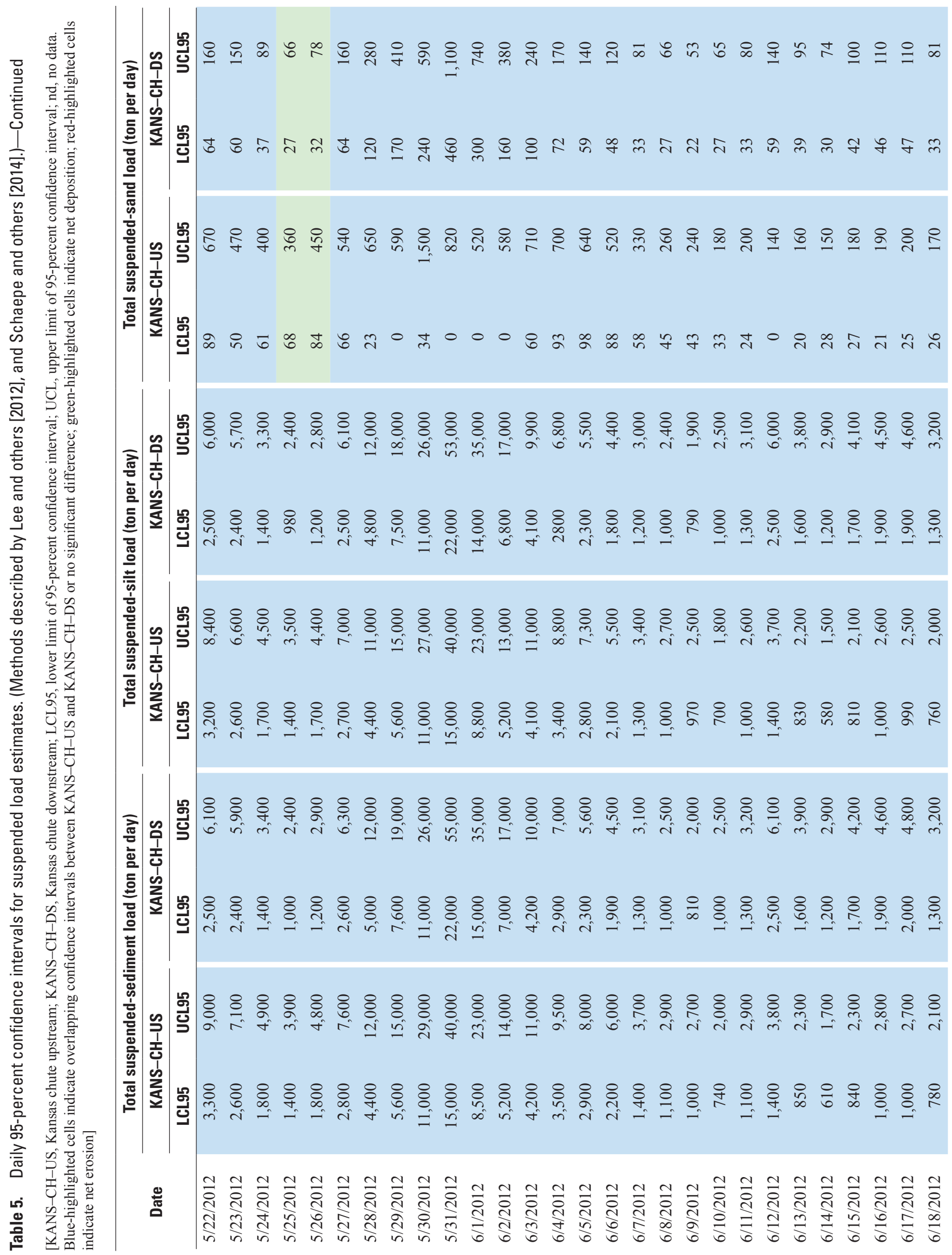




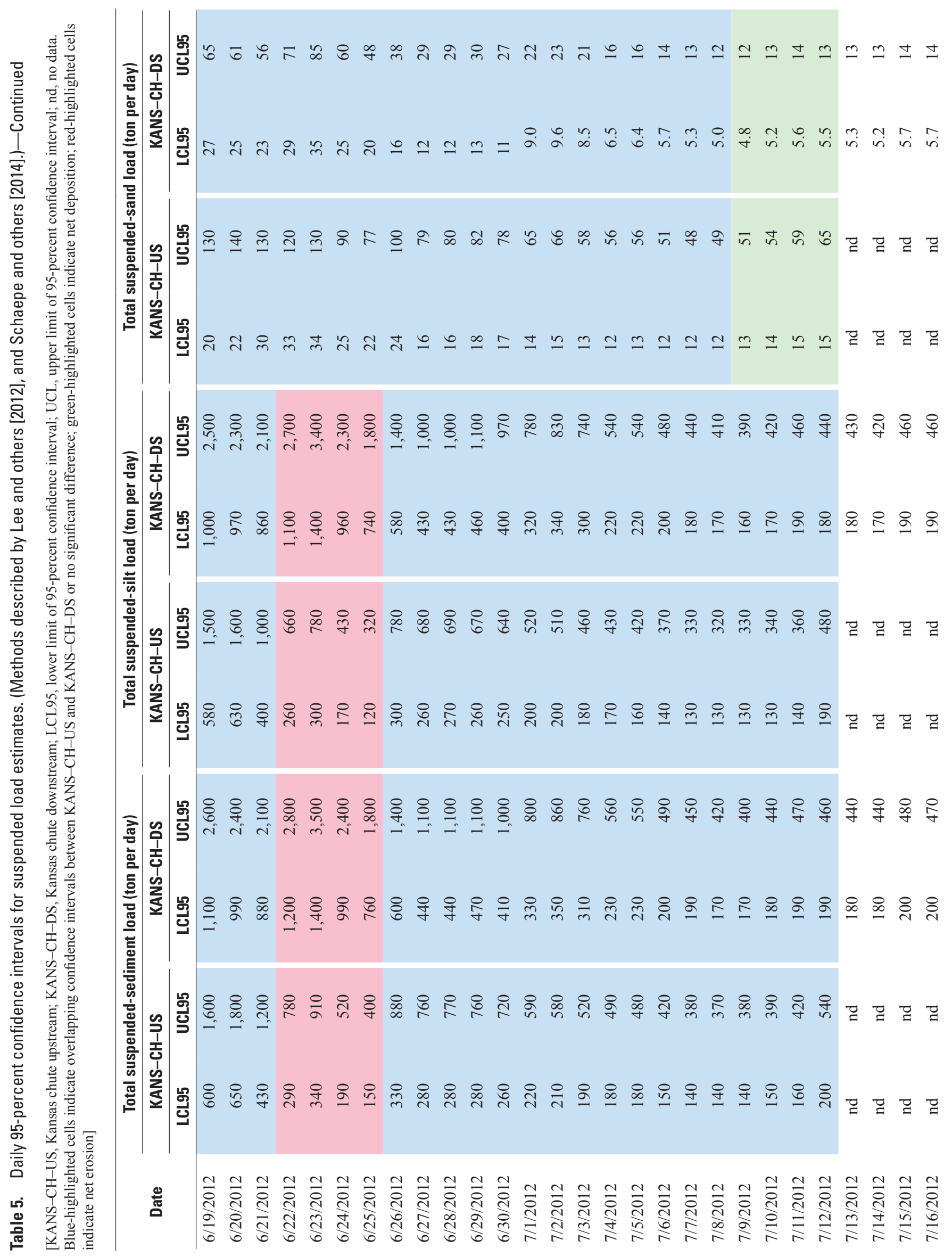




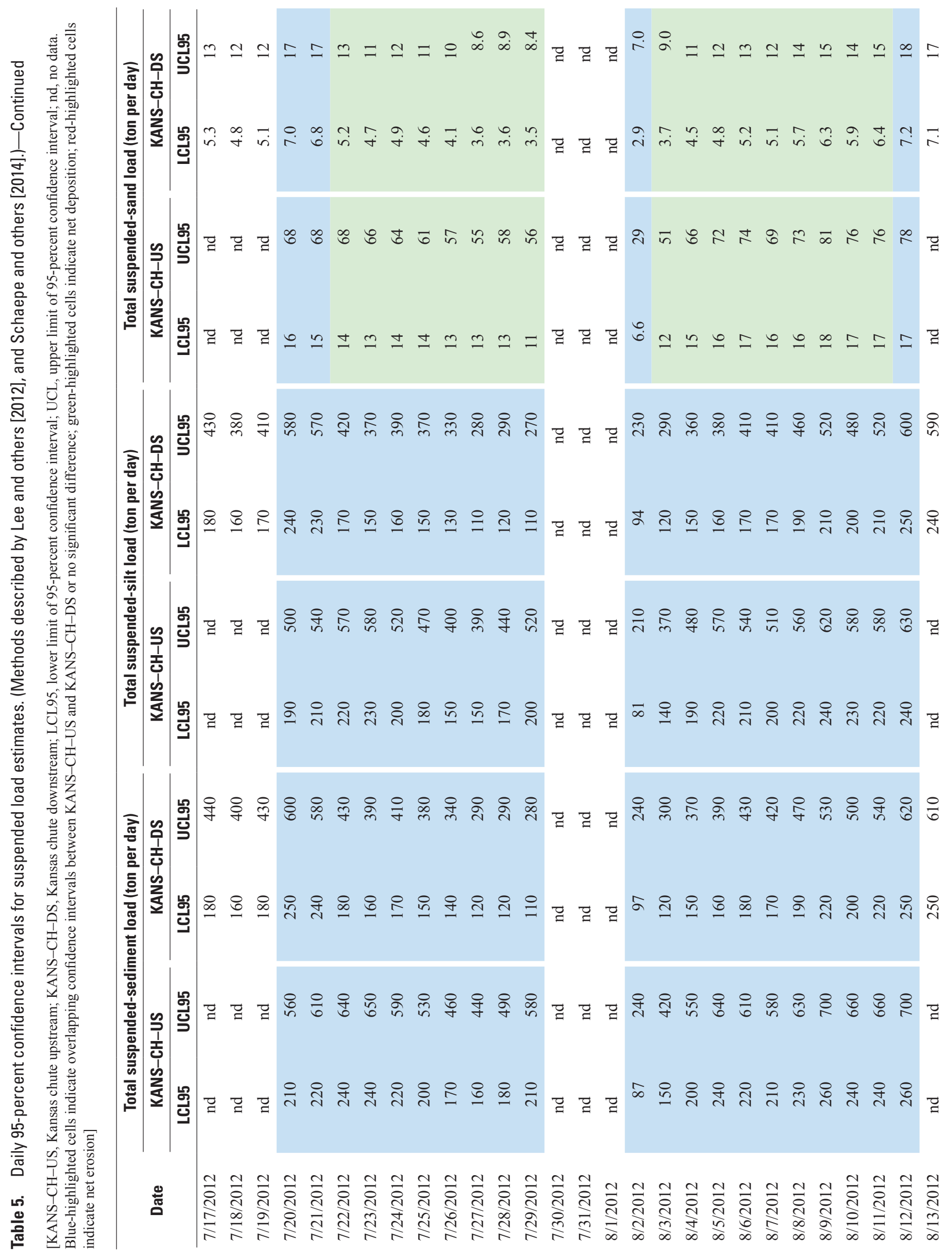




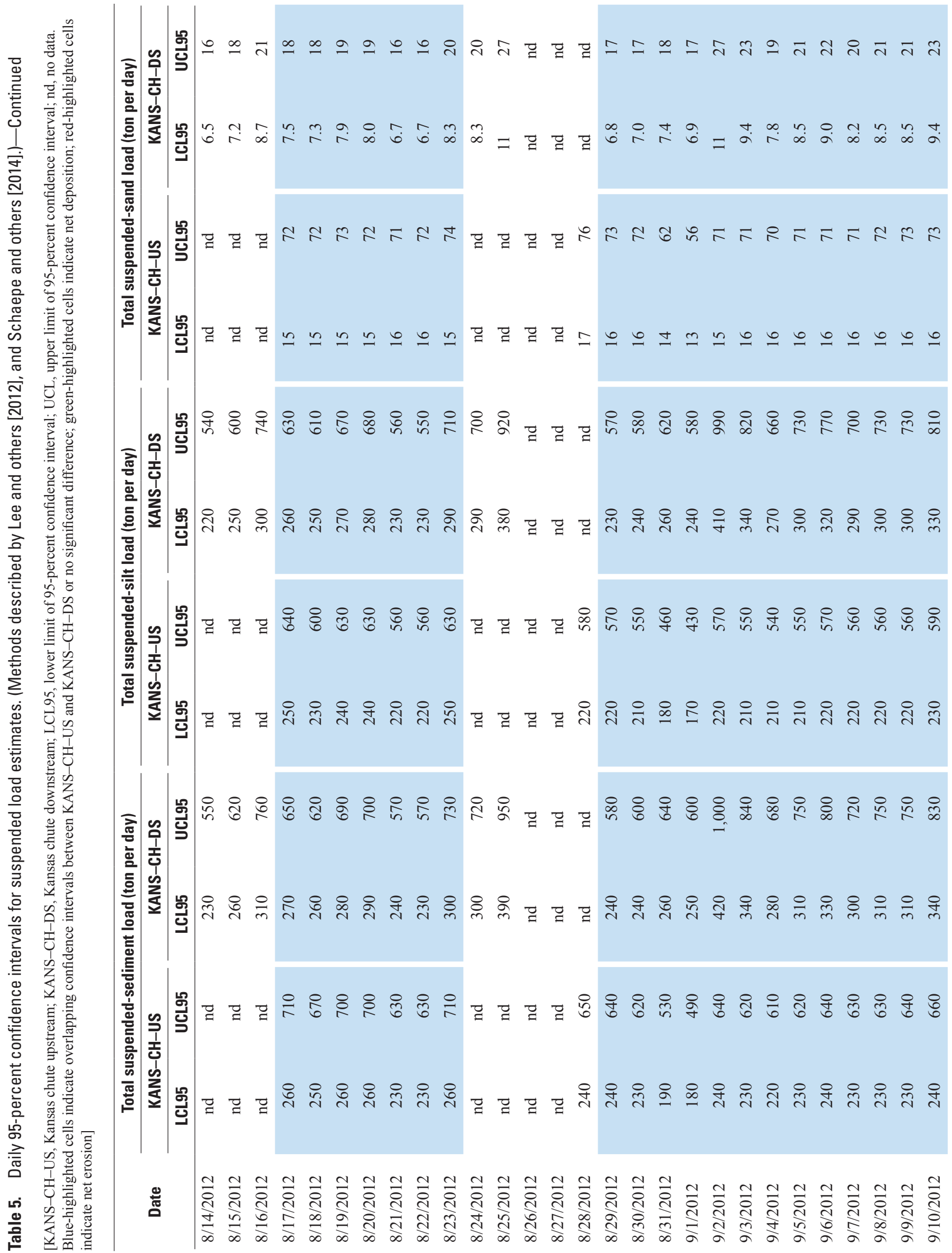




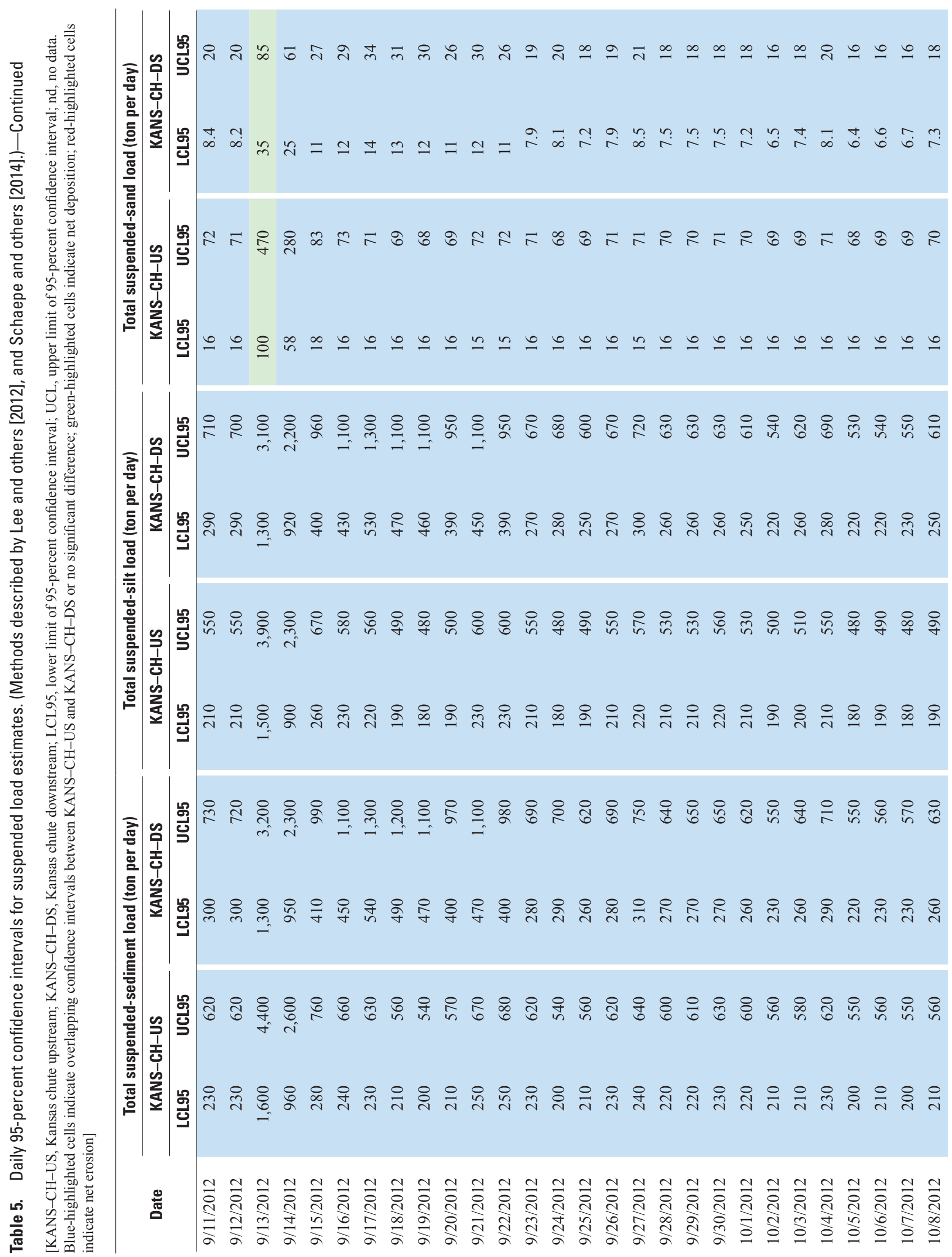




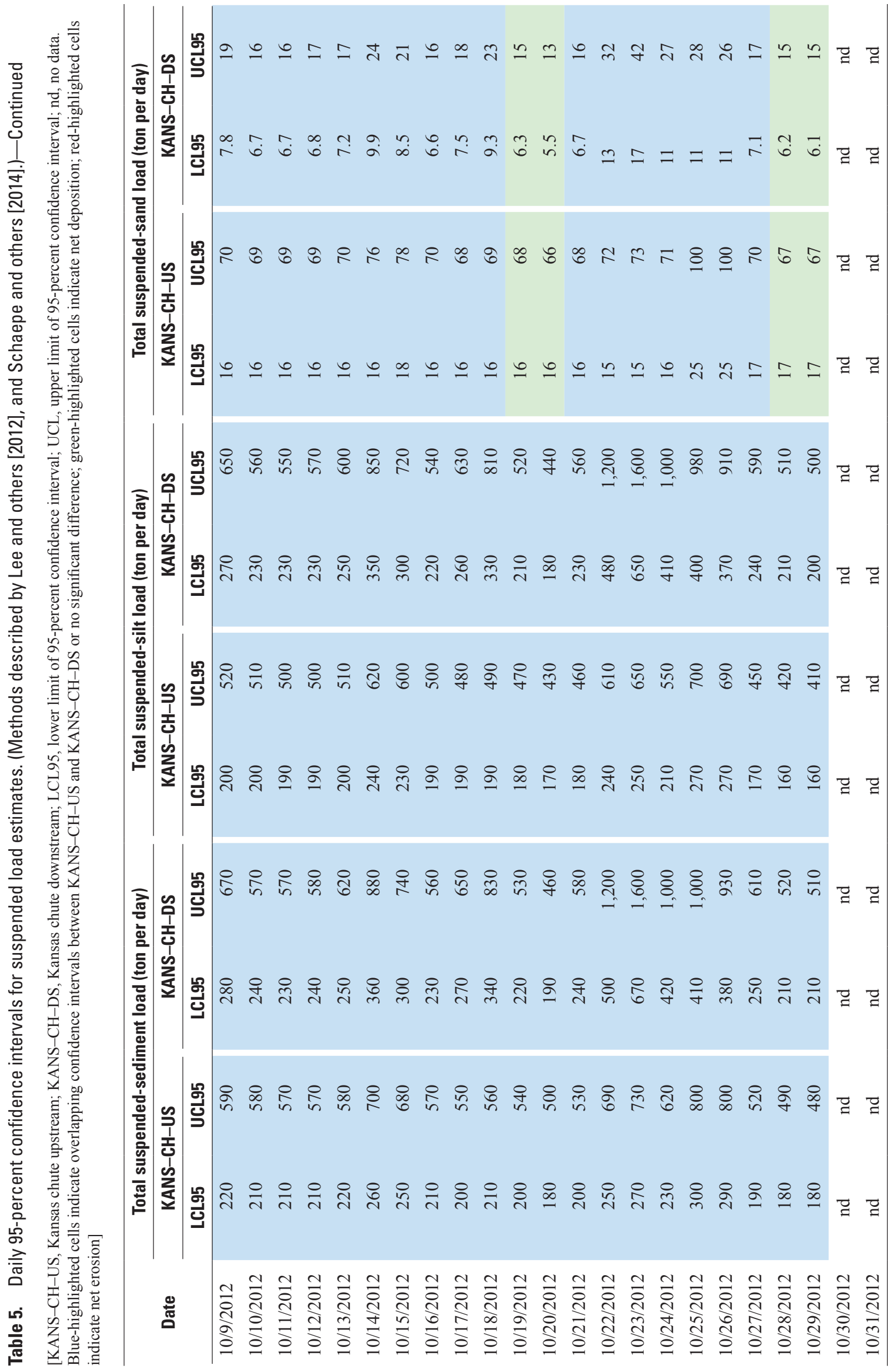



Appendix 1 
Appendix 1. Suspended sediment on the Missouri River main channel and within side channel chutes at Upper Hamburg Bend and Kansas Bend, 2012.

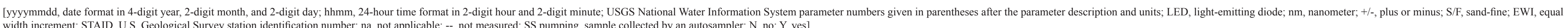

\begin{tabular}{|c|c|c|c|c|c|c|c|c|c|c|c|c|c|c|c|c|c|c|}
\hline $\begin{array}{c}\text { Date, } \\
\text { yyyymmdd }\end{array}$ & $\begin{array}{l}\text { Time, } \\
\text { hhmm }\end{array}$ & $\begin{array}{c}\text { Sampling } \\
\text { method code } \\
\text { (82398) }\end{array}$ & $\begin{array}{c}\text { Con- } \\
\text { struction }\end{array}$ & $\begin{array}{l}\text { Discharge, } \\
\text { instantaneous, } \\
\text { cubic foot per } \\
\text { second (00061) }\end{array}$ & $\begin{array}{c}\text { Temperature, } \\
\text { water, } \\
\text { degrees } \\
\text { Celsius } \\
(00010)\end{array}$ & $\begin{array}{c}\text { Turbidity, water, un- } \\
\text { filtered, monochrome } \\
\text { near infra-red LED light, } \\
780-900 \mathrm{~nm} \text {, detection } \\
\text { angle } 90++-2.5 \text { degrees, } \\
\text { formazin nephelometric } \\
\text { units (63680) } \\
\end{array}$ & $\begin{array}{c}\text { Suspended } \\
\text { sediment, fall } \\
\text { diameter (deion- } \\
\text { ized water), } \\
\text { percent smaller } \\
\text { than 0.0625 mil- } \\
\text { limeter (70342) } \\
\end{array}$ & $\begin{array}{c}\text { Suspended } \\
\text { sediment, fall } \\
\text { diameter (deion- } \\
\text { ized water), per- } \\
\text { cent smaller than } \\
0.125 \text { millimeter } \\
\text { (70343) } \\
\end{array}$ & $\begin{array}{c}\text { Suspended } \\
\text { sediment, fall } \\
\text { diameter (deion- } \\
\text { ized water), per- } \\
\text { cent smaller than } \\
0.25 \text { millimeter } \\
\text { (70344) } \\
\end{array}$ & $\begin{array}{c}\text { Suspended } \\
\text { sediment, fall } \\
\text { diameter (deion- } \\
\text { ized water), } \\
\text { percent smaller } \\
\text { than } 0.5 \text { millime- } \\
\text { ter (70345) } \\
\end{array}$ & $\begin{array}{l}\text { Suspended } \\
\text { sediment, sieve } \\
\text { diameter, percent } \\
\text { smaller than } \\
0.0625 \text { millimeter } \\
\text { (70331) }\end{array}$ & $\begin{array}{c}\text { S/F } \\
\text { split }\end{array}$ & $\begin{array}{c}\text { Suspended } \\
\text { sediment, } \\
\text { sieve diameter, } \\
\text { percent smaller } \\
\text { than } 1 \text { millime- } \\
\text { ter (70335) }\end{array}$ & $\begin{array}{c}\text { Suspended } \\
\text { sediment, } \\
\text { sieve diameter, } \\
\text { percent smaller } \\
\text { than } 2 \text { millime- } \\
\text { ters (70336) }\end{array}$ & $\begin{array}{c}\text { Suspended } \\
\text { sediment } \\
\text { concentration, } \\
\text { milligrams per } \\
\text { liter (80154) }\end{array}$ & $\begin{array}{c}\text { Suspended } \\
\text { sediment } \\
\text { concentration, } \\
\text { milligrams } \\
\text { per liter, } \\
\text { estimated EWI } \\
\text { concentration } \\
\end{array}$ & $\begin{array}{c}\text { Suspended } \\
\text { silt sediment } \\
\text { concentration, } \\
\text { milligrams } \\
\text { per liter, } \\
\text { estimated EWI } \\
\text { concentration } \\
\end{array}$ & $\begin{array}{c}\text { Suspended } \\
\text { sand sediment } \\
\text { concentration, } \\
\text { milligrams } \\
\text { per liter, } \\
\text { estimated EWI } \\
\text { concentration }\end{array}$ \\
\hline \multicolumn{19}{|c|}{ Upper Hamburg Missouri River upstream (STAID 403712095460601) } \\
\hline 20120430 & 1240 & EWI & na & -- & 15.2 & 57 & -- & -- & -- & -- & -- & - & -- & -- & 230 & 230 & -- & -- \\
\hline 20120521 & 1730 & EWI & na & 43,300 & -- & 67 & 81 & 84 & 95 & 100 & -- & 81 & -- & -- & 188 & 188 & 152 & 36 \\
\hline 20120618 & 1530 & EWI & na & 42,600 & 26.3 & -- & 65 & 69 & 93 & 99 & -- & 65 & 100 & -- & 283 & 283 & 184 & 99 \\
\hline 20120718 & 1245 & EWI & na & 36,100 & -- & 40 & 50 & 57 & 90 & 100 & -- & 50 & -- & -- & 141 & 141 & 71 & 71 \\
\hline 20120816 & 1420 & EWI & na & 36,900 & -- & -- & 13 & 19 & 36 & 57 & -- & 13 & 98 & 100 & 730 & 730 & 95 & 635 \\
\hline 20120816 & ${ }^{1} 1435$ & EWI & na & 36,900 & -- & -- & 13 & 16 & 32 & 51 & -- & 13 & 94 & 100 & 697 & 697 & 91 & 606 \\
\hline 20120910 & 1150 & EWI & na & 38,500 & -- & -- & 75 & 80 & 92 & 96 & -- & 75 & 100 & -- & 136 & 136 & 102 & 34 \\
\hline 20121009 & 1330 & EWI & na & 39,200 & -- & -- & 36 & 45 & 91 & 100 & -- & 36 & -- & -- & 178 & 178 & 64 & 114 \\
\hline \multicolumn{19}{|c|}{ Upper Hamburg Missouri River downstream (STAID 403438095462501) } \\
\hline 20120430 & 1340 & EWI & na & -- & 15.7 & 60 & -- & -- & -- & -- & -- & - & -- & -- & 346 & 346 & -- & -- \\
\hline 20120521 & 1600 & EWI & na & 43,300 & -- & 65 & 88 & 92 & 97 & 100 & -- & 88 & -- & -- & 171 & 171 & 150 & 21 \\
\hline 20120618 & 1437 & EWI & na & 42,600 & 25.3 & -- & 66 & 71 & 95 & 100 & -- & 66 & -- & -- & 272 & 272 & 180 & 92 \\
\hline 20120718 & 1645 & EWI & na & 36,100 & -- & 40 & 11 & 13 & 40 & 95 & -- & 11 & 100 & -- & 680 & 680 & 75 & 605 \\
\hline 20120816 & 1340 & EWI & na & 36,900 & -- & -- & 28 & 33 & 47 & 80 & -- & 28 & 98 & 100 & 365 & 365 & 102 & 263 \\
\hline 20120910 & 1540 & EWI & na & 38,500 & -- & -- & 25 & 26 & 31 & 36 & -- & 25 & 40 & 43 & 380 & 380 & 95 & 285 \\
\hline 20121009 & 1540 & EWI & na & 39,200 & -- & -- & -- & 14 & 37 & 62 & -- & -- & 97 & 100 & 613 & 613 & -- & -- \\
\hline \multicolumn{19}{|c|}{ Upper Hamburg chute downstream (STAID 403455095462401) } \\
\hline 20120415 & 0337 & SS pumping & $\mathrm{N}$ & 5,580 & 14.0 & -- & -- & -- & -- & -- & 97 & 97 & -- & -- & 622 & 561 & 544 & 17 \\
\hline 20120415 & 1204 & SS pumping & $\mathrm{N}$ & 6,740 & 14.0 & -- & -- & -- & -- & -- & 100 & 100 & -- & -- & -- & -- & -- & -- \\
\hline 20120415 & 1251 & SS pumping & $\mathrm{N}$ & 6,750 & 14.1 & -- & -- & -- & -- & -- & 99 & 99 & -- & -- & -- & -- & -- & -- \\
\hline 20120430 & 1600 & EWI & $\mathrm{N}$ & 3,690 & 16.6 & 130 & -- & -- & -- & -- & -- & -- & -- & -- & 365 & 365 & -- & -- \\
\hline 20120521 & 1500 & EWI & $\mathrm{N}$ & 4,880 & 21.1 & 58 & 99 & 99 & 100 & -- & -- & 99 & -- & -- & 140 & 140 & 139 & 1 \\
\hline 20120618 & 1310 & EWI & $\mathrm{N}$ & 4,810 & 25.1 & 81 & -- & -- & -- & -- & 97 & 97 & -- & -- & 160 & 160 & 155 & 5 \\
\hline 20120618 & 1340 & SS pumping & $\mathrm{N}$ & 4,810 & 25.2 & 85 & -- & -- & -- & -- & 97 & 97 & -- & -- & 196 & 185 & 179 & 6 \\
\hline 20120718 & 1545 & EWI & Y & 1,240 & 25.7 & 78 & 97 & 97 & 99 & 100 & -- & 97 & -- & -- & -- & -- & -- & -- \\
\hline 20120731 & 1030 & SS pumping & Y & 1,220 & 28.8 & 22 & -- & -- & -- & -- & 73 & 73 & -- & -- & 66 & 70 & 51 & 19 \\
\hline 20120803 & 1030 & SS pumping & Y & 1,210 & 30.0 & 21 & -- & -- & -- & -- & 97 & 97 & -- & -- & 39 & 46 & 44 & 1 \\
\hline 20120804 & 1030 & SS pumping & Y & 962 & 29.3 & 27 & -- & -- & -- & -- & 98 & 98 & -- & -- & 71 & 74 & 73 & 1 \\
\hline 20120806 & 1030 & SS pumping & $\mathrm{Y}$ & 1,370 & 28.1 & 26 & -- & -- & -- & -- & 98 & 98 & -- & -- & 51 & 56 & 55 & 1 \\
\hline 20120808 & 1030 & SS pumping & Y & 1,390 & 28.2 & 30 & -- & -- & -- & -- & 99 & 99 & -- & -- & 43 & 49 & 49 & 0 \\
\hline 20120810 & 1030 & SS pumping & Y & 1,200 & 27.3 & 27 & -- & -- & -- & -- & 98 & 98 & -- & -- & 45 & 51 & 50 & 1 \\
\hline 20120812 & 1030 & SS pumping & Y & 1,340 & 27.1 & 23 & -- & -- & -- & -- & 96 & 96 & -- & -- & 39 & 46 & 44 & 2 \\
\hline 20120814 & 1030 & SS pumping & Y & 1,150 & 25.7 & 28 & -- & -- & -- & -- & 98 & 98 & -- & -- & 49 & 55 & 54 & 1 \\
\hline 20120816 & 1300 & EWI & Y & 1,210 & 24.7 & 26 & -- & -- & -- & -- & 97 & 97 & -- & -- & 58 & 58 & 56 & 2 \\
\hline 20120818 & 1030 & SS pumping & Y & 1,170 & 24.6 & 33 & -- & -- & -- & -- & 99 & 99 & -- & -- & 48 & 54 & 53 & 1 \\
\hline 20120819 & 1030 & SS pumping & Y & 1,360 & 23.6 & 30 & -- & -- & -- & -- & 97 & 97 & -- & -- & 48 & 54 & 52 & 2 \\
\hline 20120822 & 1030 & SS pumping & Y & 1,390 & 24.1 & 27 & -- & -- & -- & -- & 99 & 99 & -- & -- & 37 & 44 & 44 & 0 \\
\hline
\end{tabular}


Appendix 1. Suspended sediment on the Missouri River main channel and within side channel chutes at Upper Hamburg Bend and Kansas Bend, 2012.-Continued

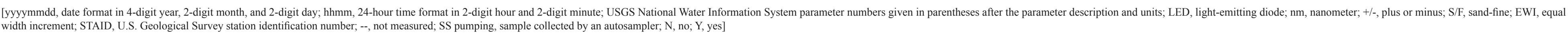

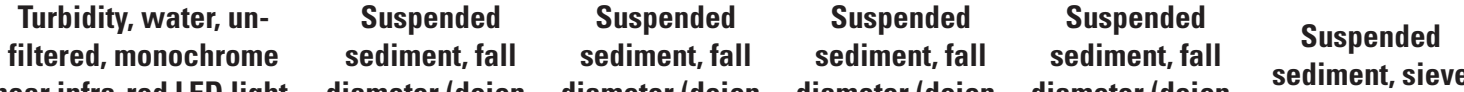

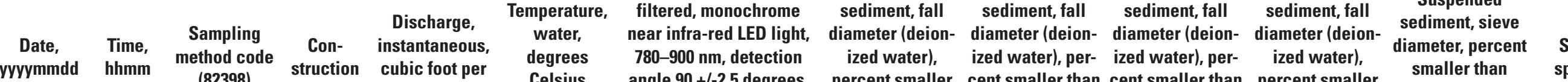
(20398) struction cecond (00061) Celsius

pent smaller than cent smaller than percent smaller 0.0625 millime (70343)

$(70344)$
$(25$ millimeter

ter (70345)

(70331)

Upper Hamburg chute downstream (STAID 403455095462401)—Continued

\begin{tabular}{|c|c|c|c|c|c|c|c|c|c|}
\hline & & & & & & & & & \\
\hline 20120823 & 1030 & SS pumping & $\mathrm{Y}$ & 1,200 & 23.9 & 27 & -- & -- & -- \\
\hline 20120827 & 1030 & SS pumping & $\mathrm{Y}$ & 1,410 & 25.0 & 26 & -- & -- & -- \\
\hline 20120901 & 1200 & SS pumping & $\mathrm{Y}$ & 1,220 & 26.8 & 31 & -- & -- & -- \\
\hline 20120903 & 1200 & SS pumping & $\mathrm{Y}$ & 1,420 & 27.4 & 42 & -- & -- & -- \\
\hline 20120907 & 1200 & SS pumping & $\mathrm{Y}$ & 1,150 & 25.5 & 37 & -- & -- & -- \\
\hline 20120909 & 1200 & SS pumping & $\mathrm{Y}$ & 1,270 & 23.6 & 28 & -- & -- & -- \\
\hline 20120910 & 1200 & SS pumping & $\mathrm{Y}$ & 1,270 & 23.3 & 32 & -- & -- & -- \\
\hline 20120910 & 1510 & EWI & $\mathrm{Y}$ & 1,010 & 23.7 & 41 & -- & -- & -- \\
\hline 20120911 & 1200 & SS pumping & $\mathrm{Y}$ & 1,010 & 23.2 & 32 & -- & -- & -- \\
\hline 20120913 & 1200 & SS pumping & $\mathrm{Y}$ & 1,410 & 21.4 & 36 & -- & -- & -- \\
\hline 20120915 & 1200 & SS pumping & $\mathrm{Y}$ & 1,460 & 21.3 & 32 & -- & -- & -- \\
\hline 20120919 & 1200 & SS pumping & $\mathrm{Y}$ & 1,160 & 20.5 & 30 & -- & -- & -- \\
\hline 20120925 & 1200 & SS pumping & $\mathrm{Y}$ & 1,390 & 19.2 & 30 & -- & -- & -- \\
\hline 20121005 & 1200 & SS pumping & $\mathrm{Y}$ & 1,150 & 17.2 & 26 & -- & -- & -- \\
\hline 20121009 & 1420 & SS pumping & $\mathrm{Y}$ & 1,180 & 14.4 & 34 & 95 & 96 & 9 \\
\hline 20121009 & 1500 & EWI & $\mathrm{Y}$ & 1,040 & 14.0 & 33 & -- & 93 & 9 \\
\hline 20121013 & 1600 & SS pumping & $\mathrm{Y}$ & 1,170 & 14.0 & 44 & -- & -- & -- \\
\hline 20121019 & 1600 & SS pumping & $\mathrm{Y}$ & 1,170 & 13.0 & 35 & -- & -- & - \\
\hline
\end{tabular}

\begin{tabular}{|c|c|c|c|c|}
\hline-- & 96 & 96 & -- & -- \\
\hline -- & 98 & 98 & -- & -- \\
\hline -- & 99 & 99 & -- & -- \\
\hline -- & 100 & 100 & -- & -- \\
\hline -- & 98 & 98 & -- & -- \\
\hline -- & 98 & 98 & -- & -- \\
\hline -- & 97 & 97 & -- & -- \\
\hline -- & 92 & 92 & -- & -- \\
\hline -- & 95 & 95 & -- & -- \\
\hline -- & 98 & 98 & -- & -- \\
\hline -- & 95 & 95 & -- & -- \\
\hline -- & 100 & 100 & -- & - \\
\hline-- & 97 & 97 & -- & -- \\
\hline-- & 99 & 99 & -- & - \\
\hline 97 & -- & 95 & 100 & - \\
\hline 100 & -- & -- & -- & -- \\
\hline -- & 98 & 98 & -- & -- \\
\hline -- & 100 & 100 & --- & -- \\
\hline
\end{tabular}

$201204251130 \quad$ EWI 35,100

$20120522-1130-$ EWI $\quad 35,100$

$20120622 \quad 1130 \quad$ EWI

$20120817 \quad 1418 \quad$ EWI

$20120911 \quad 0916$

$35,100 \quad 15,0$

Kansas Missouri River upstream (STAID 403126095433301) Suspended Suspended Suspended Suspended Suspended

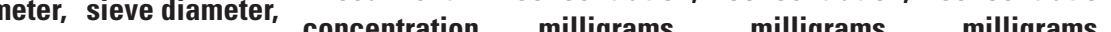
ercent smaller percent smaller milligrams per pe liter per lis 1 millime- than 2 millime- - liter (80154) estimated EWI estimated EWI estimated EWI concentration concentration concentration

\begin{tabular}{|c|c|c|c|c|c|c|c|c|c|c|c|c|c|c|c|c|c|}
\hline \multicolumn{18}{|c|}{ Kansas Missouri River downstream (STAID 40403055095422901) } \\
\hline 20120425 & 1430 & EWI & 35,100 & 14.9 & 66 & -- & -- & -- & -- & -- & -- & 97 & 100 & 363 & 363 & -- & -- \\
\hline 20120522 & 1730 & EWI & 46,800 & 21.4 & 150 & -- & -- & -- & -- & -- & -- & 100 & -- & 438 & 438 & -- & -- \\
\hline 20120622 & 1332 & EWI & 44,700 & 26.2 & 130 & -- & -- & -- & -- & -- & -- & 99 & 100 & 548 & 548 & -- & -- \\
\hline 20120719 & 1500 & EWI & 34,800 & -- & 47 & -- & -- & -- & -- & -- & -- & 82 & 98 & 537 & 537 & -- & -- \\
\hline 20120817 & 1535 & EWI & 38,400 & -- & -- & -- & -- & -- & -- & -- & -- & 93 & 100 & 435 & 435 & -- & -- \\
\hline 20120911 & 1330 & EWI & 38,800 & -- & -- & 83 & 91 & 98 & 100 & -- & 83 & -- & -- & 90 & 90 & 75 & 15 \\
\hline
\end{tabular}


Appendix 1. Suspended sediment on the Missouri River main channel and within side channel chutes at Upper Hamburg Bend and Kansas Bend, 2012. - Continued

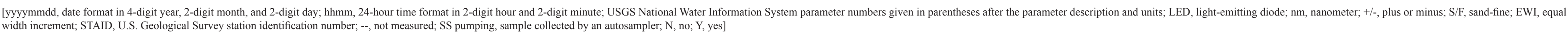

\begin{tabular}{|c|c|c|c|c|c|c|c|c|c|c|c|c|c|c|c|c|c|c|}
\hline $\begin{array}{c}\text { Date, } \\
\text { yyyymmdd }\end{array}$ & $\begin{array}{l}\text { Time, } \\
\text { hhmm }\end{array}$ & $\begin{array}{c}\text { Sampling } \\
\text { method code } \\
\text { (82398) }\end{array}$ & $\begin{array}{c}\text { Con- } \\
\text { struction }\end{array}$ & $\begin{array}{l}\text { Discharge, } \\
\text { instantaneous, } \\
\text { cubic foot per } \\
\text { second (00061) }\end{array}$ & $\begin{array}{c}\text { Temperature, } \\
\text { water, } \\
\text { degrees } \\
\text { Celsius } \\
\text { (00010) }\end{array}$ & $\begin{array}{c}\text { Turbidity, water, un- } \\
\text { filtered, monochrome } \\
\text { near infra-red LED light, } \\
780-900 \mathrm{~nm} \text {, detection } \\
\text { angle } 90++-2.5 \text { degrees, } \\
\text { formazin nephelometric } \\
\text { units (63680) } \\
\end{array}$ & $\begin{array}{c}\text { Suspended } \\
\text { sediment, fall } \\
\text { diameter (deion- } \\
\text { ized water), } \\
\text { percent smaller } \\
\text { than 0.0625 mil- } \\
\text { limeter (70342) } \\
\end{array}$ & $\begin{array}{c}\text { Suspended } \\
\text { sediment, fall } \\
\text { diameter (deion- } \\
\text { ized water), per- } \\
\text { cent smaller than } \\
0.125 \text { millimeter } \\
\text { (70343) } \\
\end{array}$ & $\begin{array}{c}\text { Suspended } \\
\text { sediment, fall } \\
\text { diameter (deion- } \\
\text { ized water), per- } \\
\text { cent smaller than } \\
0.25 \text { millimeter } \\
\text { (70344) } \\
\end{array}$ & $\begin{array}{c}\text { Suspended } \\
\text { sediment, fall } \\
\text { diameter (deion- } \\
\text { ized water), } \\
\text { percent smaller } \\
\text { than } 0.5 \text { millime- } \\
\text { ter (70345) } \\
\end{array}$ & $\begin{array}{c}\text { Suspended } \\
\text { sediment, sieve } \\
\text { diameter, percent } \\
\text { smaller than } \\
\text { 0.0625 millimeter } \\
\text { (70331) }\end{array}$ & $\begin{array}{l}\text { S/F } \\
\text { split }\end{array}$ & $\begin{array}{l}\text { Suspended } \\
\text { sediment, } \\
\text { sieve diameter, } \\
\text { percent smaller } \\
\text { than } 1 \text { millime- } \\
\text { ter (70335) }\end{array}$ & $\begin{array}{c}\text { Suspended } \\
\text { sediment, } \\
\text { sieve diameter, } \\
\text { percent smaller } \\
\text { than } 2 \text { millime- } \\
\text { ters (70336) }\end{array}$ & $\begin{array}{c}\text { Suspended } \\
\text { sediment } \\
\text { concentration, } \\
\text { milligrams per } \\
\text { liter (80154) }\end{array}$ & $\begin{array}{c}\text { Suspended } \\
\text { sediment } \\
\text { concentration, } \\
\text { milligrams } \\
\text { per liter, } \\
\text { estimated EWI } \\
\text { concentration } \\
\end{array}$ & $\begin{array}{c}\text { Suspended } \\
\text { silt sediment } \\
\text { concentration, } \\
\text { milligrams } \\
\text { per liter, } \\
\text { estimated EWI } \\
\text { concentration } \\
\end{array}$ & $\begin{array}{c}\text { Suspended } \\
\text { sand sediment } \\
\text { concentration, } \\
\text { milligrams } \\
\text { per liter, } \\
\text { estimated EWI } \\
\text { concentration } \\
\end{array}$ \\
\hline \multicolumn{19}{|c|}{ Kansas chute upstream (STAID 403135095431201) } \\
\hline 20120425 & 1300 & EWI & $\mathrm{N}$ & 4,920 & 14.6 & 53 & -- & -- & -- & -- & -- & -- & -- & -- & 252 & 252 & -- & -- \\
\hline 20120507 & 0237 & SS pumping & $\mathrm{N}$ & 9,110 & 22.9 & 190 & -- & -- & -- & -- & 94 & 94 & -- & -- & 291 & 268 & 252 & 16 \\
\hline 20120507 & 0837 & SS pumping & $\mathrm{N}$ & 9,560 & 22.2 & 151 & -- & -- & -- & -- & 99 & 99 & -- & -- & 694 & 624 & 618 & 6 \\
\hline 20120507 & 1437 & SS pumping & $\mathrm{N}$ & 8,830 & 21.8 & 170 & -- & -- & -- & -- & 98 & 98 & -- & -- & 465 & 422 & 414 & 8 \\
\hline 20120508 & 0237 & SS pumping & $\mathrm{N}$ & 8,280 & 21.6 & 179 & -- & -- & -- & -- & 99 & 99 & -- & -- & 526 & 476 & 471 & 5 \\
\hline 20120508 & 0837 & SS pumping & $\mathrm{N}$ & 7,740 & 20.9 & 277 & -- & -- & -- & -- & 99 & 99 & -- & -- & 498 & 451 & 447 & 5 \\
\hline 20120508 & 1437 & SS pumping & $\mathrm{N}$ & 7,210 & 20.5 & 321 & -- & -- & -- & -- & 100 & 100 & -- & -- & 614 & 554 & 554 & 0 \\
\hline 20120509 & 0237 & SS pumping & $\mathrm{N}$ & 6,880 & 20.2 & 190 & -- & -- & -- & -- & 99 & 99 & -- & -- & 562 & 508 & 503 & 5 \\
\hline 20120509 & 0837 & SS pumping & $\mathrm{N}$ & 6,920 & 19.4 & 170 & -- & -- & -- & -- & 99 & 99 & -- & -- & 368 & 336 & 333 & 3 \\
\hline 20120509 & 1457 & SS pumping & $\mathrm{N}$ & 6,290 & 19.1 & 160 & -- & -- & -- & -- & 98 & 98 & -- & -- & 373 & 341 & 334 & 7 \\
\hline 20120513 & 2235 & SS pumping & Y & 9,400 & 19.1 & 150 & -- & -- & -- & -- & 98 & 98 & -- & -- & 399 & 364 & 357 & 7 \\
\hline 20120514 & 0435 & SS pumping & Y & 10,500 & 19.9 & 140 & -- & -- & -- & -- & 98 & 98 & -- & -- & 391 & 357 & 350 & 7 \\
\hline 20120514 & 2235 & SS pumping & Y & 11,100 & 19.5 & 110 & -- & -- & -- & -- & 96 & 96 & -- & -- & 414 & 377 & 362 & 15 \\
\hline 20120515 & 1035 & SS pumping & Y & 10,200 & 18.9 & 98 & -- & -- & -- & -- & 98 & 98 & -- & -- & 276 & 255 & 250 & 5 \\
\hline 20120515 & 1635 & SS pumping & Y & 10,700 & 18.4 & 93 & -- & -- & -- & -- & 99 & 99 & -- & -- & 276 & 255 & 253 & 3 \\
\hline 20120515 & 2235 & SS pumping & Y & 9,660 & 19.6 & 84 & -- & -- & -- & -- & 98 & 98 & -- & -- & 267 & 247 & 242 & 5 \\
\hline 20120516 & 0435 & SS pumping & Y & 9,550 & 19.3 & 81 & -- & -- & -- & -- & 97 & 97 & -- & -- & 275 & 254 & 247 & 8 \\
\hline 20120516 & 1635 & SS pumping & Y & 9,210 & 19.4 & 74 & -- & -- & -- & -- & 97 & 97 & -- & -- & 244 & 227 & 220 & 7 \\
\hline 20120519 & 1635 & SS pumping & Y & 6,890 & 20.4 & 51 & -- & -- & -- & -- & 98 & 98 & -- & -- & 350 & 321 & 314 & 6 \\
\hline 20120522 & 1415 & EWI & Y & 7,190 & 21.2 & 130 & 79 & 81 & 87 & 98 & -- & 79 & 100 & -- & 352 & 352 & 278 & 74 \\
\hline 20120530 & 1938 & SS pumping & Y & 12,800 & 22.8 & 249 & -- & -- & -- & -- & 99 & 99 & -- & -- & 613 & 553 & 547 & 6 \\
\hline 20120531 & 0138 & SS pumping & Y & 13,900 & 22.3 & 379 & -- & -- & -- & -- & 100 & 100 & -- & -- & 794 & 713 & 713 & 0 \\
\hline 20120622 & 1200 & EWI & Y & 3,010 & 25.0 & 18 & 98 & 98 & 99 & 100 & -- & 98 & -- & -- & -- & -- & -- & -- \\
\hline 20120703 & 1030 & SS pumping & $\mathrm{N}$ & 2,010 & 29.8 & 37 & -- & -- & -- & -- & 96 & 96 & -- & -- & 42 & 48 & 47 & 2 \\
\hline 20120719 & 1145 & EWI & $\mathrm{N}$ & 1,950 & 25.6 & 25 & 95 & 95 & 96 & 100 & -- & 95 & -- & -- & 70 & 70 & 67 & 4 \\
\hline 20120817 & 1235 & SS pumping & $\mathrm{N}$ & 2,020 & 24.7 & 54 & -- & -- & -- & -- & 98 & 98 & -- & -- & 48 & 54 & 53 & 1 \\
\hline 20120817 & 1240 & EWI & $\mathrm{N}$ & 2,020 & 24.8 & 44 & 93 & 94 & 95 & 100 & -- & 93 & -- & -- & 98 & 98 & 91 & 7 \\
\hline 20120911 & 1023 & SS pumping & $\mathrm{N}$ & 2,030 & 22.5 & 29 & -- & -- & -- & -- & 99 & 99 & -- & -- & 54 & 59 & 58 & 1 \\
\hline 20120911 & 1040 & EWI & $\mathrm{N}$ & 2,030 & 22.9 & 33 & -- & -- & -- & -- & 97 & 97 & -- & -- & 68 & 68 & 66 & 2 \\
\hline 20121010 & 1000 & EWI & $\mathrm{N}$ & 1,900 & 13.6 & 23 & 79 & 82 & 92 & 100 & -- & 79 & -- & -- & 76 & 76 & 60 & 16 \\
\hline 20121010 & '1007 & EWI & $\mathrm{N}$ & 1,900 & 13.6 & 23 & 87 & 88 & 89 & 90 & -- & 87 & 100 & -- & 69 & 69 & 60 & 9 \\
\hline 20121010 & 1015 & SS pumping & $\mathrm{N}$ & 1,880 & 13.7 & 22 & -- & -- & -- & -- & 97 & 97 & -- & -- & 93 & 94 & 91 & 3 \\
\hline \multicolumn{19}{|c|}{ Kansas chute downstream (STAID 403134095431101) } \\
\hline 20120414 & 2336 & SS pumping & $\mathrm{N}$ & 7,470 & 13.6 & 230 & -- & -- & -- & -- & 94 & 94 & -- & -- & -- & -- & -- & -- \\
\hline 20120415 & 0536 & SS pumping & $\mathrm{N}$ & 16,100 & 13.4 & 480 & -- & -- & -- & -- & 95 & 95 & -- & -- & -- & -- & -- & -- \\
\hline 20120415 & 1136 & SS pumping & $\mathrm{N}$ & 17,500 & 13.6 & 840 & -- & -- & -- & -- & 96 & 96 & -- & -- & 3,190 & 2,829 & 2,716 & 113 \\
\hline 20120415 & 1736 & SS pumping & $\mathrm{N}$ & 18,000 & 14.0 & 820 & -- & -- & -- & -- & 99 & 99 & -- & -- & 1,780 & 1,584 & 1,568 & 16 \\
\hline
\end{tabular}


Appendix 1. Suspended sediment on the Missouri River main channel and within side channel chutes at Upper Hamburg Bend and Kansas Bend, 2012. - Continued

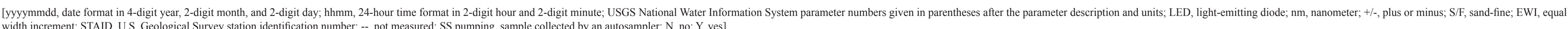

\begin{tabular}{|c|c|c|c|c|c|c|c|c|c|c|c|c|c|c|c|c|c|c|}
\hline $\begin{array}{c}\text { Date, } \\
\text { yvyymmdd }\end{array}$ & $\begin{array}{l}\text { Time, } \\
\text { hhmm }\end{array}$ & $\begin{array}{c}\text { Sampling } \\
\text { method code } \\
\text { (82398) }\end{array}$ & $\begin{array}{c}\text { Con- } \\
\text { struction }\end{array}$ & $\begin{array}{l}\text { Discharge, } \\
\text { instantaneous, } \\
\text { cubic foot per } \\
\text { second (00061) }\end{array}$ & $\begin{array}{c}\text { Temperature, } \\
\text { water, } \\
\text { degrees } \\
\text { Celsius } \\
\text { (00010) }\end{array}$ & $\begin{array}{c}\text { Turbidity, water, un- } \\
\text { filtered, monochrome } \\
\text { near infra-red LED light, } \\
780-900 \mathrm{~nm} \text {, detection } \\
\text { angle } 90++-2.5 \text { degrees, } \\
\text { formazin nephelometric } \\
\text { units (63680) }\end{array}$ & $\begin{array}{c}\text { Suspended } \\
\text { sediment, fall } \\
\text { diameter (deion- } \\
\text { ized water), } \\
\text { percent smaller } \\
\text { than } 0.0625 \text { mil- } \\
\text { limeter (70342) } \\
\end{array}$ & $\begin{array}{c}\text { Suspended } \\
\text { sediment, fall } \\
\text { diameter (deion- } \\
\text { ized water), per- } \\
\text { cent smaller than } \\
0.125 \text { millimeter } \\
\text { (70343) } \\
\end{array}$ & $\begin{array}{c}\text { Suspended } \\
\text { sediment, fall } \\
\text { diameter (deion- } \\
\text { ized water), per- } \\
\text { cent smaller than } \\
0.25 \text { millimeter } \\
\text { (70344) } \\
\end{array}$ & $\begin{array}{c}\text { Suspended } \\
\text { sediment, fall } \\
\text { diameter (deion- } \\
\text { ized water), } \\
\text { percent smaller } \\
\text { than } 0.5 \text { millime- } \\
\text { ter (70345) } \\
\end{array}$ & $\begin{array}{c}\text { Suspended } \\
\text { sediment, sieve } \\
\text { diameter, , eprcent } \\
\text { smaller than } \\
0.0625 \text { millimeter } \\
\text { (70331) } \\
\end{array}$ & $\begin{array}{c}\text { S/F } \\
\text { split }\end{array}$ & $\begin{array}{l}\text { Suspended } \\
\text { sediment, } \\
\text { sieve diameter, } \\
\text { percent smaller } \\
\text { than } 1 \text { millime- } \\
\text { ter (70335) }\end{array}$ & $\begin{array}{c}\text { Suspended } \\
\text { sediment, } \\
\text { sieve diameter, } \\
\text { percent smaller } \\
\text { than } 2 \text { millime- } \\
\text { ters (70336) }\end{array}$ & $\begin{array}{c}\text { Suspended } \\
\text { sediment } \\
\text { concentration, } \\
\text { milligrams per } \\
\text { liter (80154) }\end{array}$ & $\begin{array}{c}\text { Suspended } \\
\text { sediment } \\
\text { concentration, } \\
\text { milligrams } \\
\text { per liter, } \\
\text { estimated EWI } \\
\text { concentration } \\
\end{array}$ & $\begin{array}{c}\text { Suspended } \\
\text { silt sediment } \\
\text { concentration, } \\
\text { milligrams } \\
\text { per liter, } \\
\text { estimated EWI } \\
\text { concentration } \\
\end{array}$ & $\begin{array}{c}\text { Suspended } \\
\text { sand sediment } \\
\text { concentration, } \\
\text { milligrams } \\
\text { per liter, } \\
\text { estimated EWI } \\
\text { concentration } \\
\end{array}$ \\
\hline \multicolumn{19}{|c|}{ Kansas chute downstream (STAID 403134095431101)—Continued } \\
\hline 20120415 & 2336 & SS pumping & $\mathrm{N}$ & 18,400 & 14.5 & 620 & -- & -- & -- & -- & 99 & 99 & -- & -- & 2,020 & 1,796 & 1,778 & 18 \\
\hline 20120416 & 0536 & SS pumping & $\mathrm{N}$ & 18,800 & 14.2 & 650 & -- & -- & -- & -- & 99 & 99 & -- & -- & 1,620 & 1,442 & 1,428 & 14 \\
\hline 20120416 & 1136 & SS pumping & $\mathrm{N}$ & 17,600 & 14.0 & 520 & -- & -- & -- & -- & 99 & 99 & -- & -- & 1,100 & 983 & 973 & 10 \\
\hline 20120416 & 1736 & SS pumping & $\mathrm{N}$ & 16,000 & 14.2 & 380 & -- & -- & -- & -- & 99 & 99 & -- & -- & 846 & 759 & 751 & 8 \\
\hline 20120417 & 0536 & SS pumping & $\mathrm{N}$ & 13,300 & 13.9 & 270 & -- & -- & -- & -- & 96 & 96 & -- & -- & 745 & 670 & 643 & 27 \\
\hline 20120417 & 1136 & SS pumping & $\mathrm{N}$ & 13,100 & 13.7 & 240 & -- & -- & -- & -- & 98 & 98 & -- & -- & 643 & 579 & 568 & 12 \\
\hline 20120417 & 1736 & SS pumping & $\mathrm{N}$ & 12,200 & 14.2 & 230 & -- & -- & -- & -- & 98 & 98 & -- & -- & 656 & 591 & 579 & 12 \\
\hline 20120417 & 2336 & SS pumping & $\mathrm{N}$ & 11,600 & 14.7 & 240 & -- & -- & -- & -- & 96 & 96 & -- & -- & 614 & 554 & 532 & 22 \\
\hline 20120425 & 1330 & EWI & $\mathrm{N}$ & 5,050 & 15.6 & 70 & -- & -- & -- & -- & -- & -- & -- & -- & -- & -- & -- & -- \\
\hline 20120522 & 1645 & EWI & $\mathrm{Y}$ & 7,460 & 21.4 & 52 & 93 & 95 & 98 & 100 & -- & 93 & -- & -- & 346 & 346 & 322 & 24 \\
\hline 20120622 & 1240 & EWI & $\mathrm{Y}$ & 2,880 & 25.0 & 120 & 98 & 98 & 100 & -- & -- & 98 & -- & -- & 267 & 267 & 262 & 5 \\
\hline 20120622 & 1250 & SS pumping & $\mathrm{Y}$ & 2,880 & 25.0 & 105 & -- & -- & -- & -- & 98 & 98 & -- & -- & 259 & 240 & 235 & 5 \\
\hline 20120703 & 0810 & SS pumping & $\mathrm{N}$ & 1,710 & 28.9 & 57 & -- & -- & -- & -- & 99 & 99 & -- & -- & 116 & 114 & 113 & 1 \\
\hline 20120719 & 1330 & EWI & $\mathrm{N}$ & 1,980 & 29.2 & 31 & 97 & 97 & 100 & -- & -- & 97 & -- & -- & 105 & 105 & 102 & 3 \\
\hline 20120911 & 1125 & SS pumping & $\mathrm{N}$ & 2,030 & 22.4 & 48 & -- & -- & -- & -- & 99 & 99 & -- & -- & 71 & 74 & 73 & 1 \\
\hline 20120911 & 1200 & EWI & $\mathrm{N}$ & 1,840 & 22.8 & 70 & 81 & 97 & 99 & 100 & -- & 81 & -- & -- & -- & -- & -- & -- \\
\hline 20120917 & 1200 & SS pumping & $\mathrm{N}$ & 1,980 & 20.5 & 94 & -- & -- & -- & -- & 99 & 99 & -- & -- & 89 & 90 & 89 & 1 \\
\hline 20120918 & 1200 & SS pumping & $\mathrm{N}$ & 1,990 & 19.8 & 78 & -- & -- & -- & -- & 97 & 97 & -- & -- & 78 & 80 & 78 & 2 \\
\hline 20120919 & 1200 & SS pumping & $\mathrm{N}$ & 2,000 & 19.6 & 76 & -- & -- & -- & -- & 98 & 98 & -- & -- & 110 & 109 & 106 & 2 \\
\hline 20120920 & 1200 & SS pumping & $\mathrm{N}$ & 1,990 & 19.7 & 58 & -- & -- & -- & -- & 97 & 97 & -- & -- & 70 & 73 & 71 & 2 \\
\hline 20120922 & 1200 & SS pumping & $\mathrm{N}$ & 1,910 & 18.9 & 69 & -- & -- & -- & -- & 98 & 98 & -- & -- & 109 & 108 & 106 & 2 \\
\hline 20120923 & 1200 & SS pumping & $\mathrm{N}$ & 1,980 & 18.2 & 43 & -- & -- & -- & -- & 99 & 99 & -- & -- & 73 & 76 & 75 & 1 \\
\hline 20120924 & 1200 & SS pumping & $\mathrm{N}$ & 1,940 & 18.0 & 49 & -- & -- & -- & -- & 99 & 99 & -- & -- & 70 & 73 & 72 & 1 \\
\hline 20120927 & 1200 & SS pumping & $\mathrm{N}$ & 1,870 & 17.9 & 52 & -- & -- & -- & -- & 97 & 97 & -- & -- & 90 & 91 & 88 & 3 \\
\hline 20120928 & 1200 & SS pumping & $\mathrm{N}$ & 1,960 & 18.1 & 46 & -- & -- & -- & -- & 96 & 96 & -- & -- & 69 & 72 & 69 & 3 \\
\hline 20120930 & 1200 & SS pumping & $\mathrm{N}$ & 2,060 & 18.5 & 47 & -- & -- & -- & -- & 97 & 97 & -- & -- & 77 & 79 & 77 & 2 \\
\hline 20121002 & 1200 & SS pumping & $\mathrm{N}$ & 2,010 & 18.5 & 38 & -- & -- & -- & -- & 98 & 98 & -- & -- & 76 & 79 & 77 & 2 \\
\hline 20121003 & 1200 & SS pumping & $\mathrm{N}$ & 1,990 & 18.5 & 51 & -- & -- & -- & -- & 99 & 99 & -- & -- & 97 & 97 & 96 & 1 \\
\hline 20121005 & 1200 & SS pumping & $\mathrm{N}$ & 1,950 & 17.0 & 40 & -- & -- & -- & -- & 98 & 98 & -- & -- & 55 & 60 & 59 & 1 \\
\hline 20121010 & 1120 & SS pumping & $\mathrm{N}$ & 1,930 & 12.9 & 42 & -- & -- & -- & -- & 98 & 98 & -- & -- & 90 & 91 & 89 & 2 \\
\hline 20121010 & 1220 & EWI & $\mathrm{N}$ & 1,900 & 13.2 & 41 & -- & -- & -- & -- & 91 & 91 & -- & -- & 64 & 64 & 58 & 6 \\
\hline 2 & 1 & SS pumping & $\mathrm{N}$ & 1,930 & 12.0 & 79 & -- & -- & -- & -- & 99 & 9 & -- & -- & 151 & 145 & 143 & 1 \\
\hline
\end{tabular}

'Replicate sample collected to assess field variability 
Publishing support provided by:

Rolla Publishing Service Center

For more information concerning this publication, contact:

Director, USGS Nebraska Water Science Center

5231 South 19th Street

Lincoln, Nebraska 68512

(402) 328-4100

Or visit the Nebraska Water Science Center Web site at:

http://ne.water.usgs.gov/ 



\section{$\frac{2}{4}$}

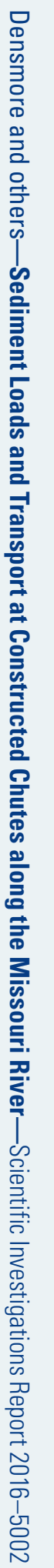

